

\section{Hydrogeology, Water Quality, and Stormwater- Sediment Chemistry of the Grande Wash Area, Fort McDowell Indian Reservation, Maricopa County, Arizona}

Water-Resources Investigations Report 00—4116

Prepared in cooperation with the

FORT McDOWELL YAVAPAI NATION 


\section{U.S. DEPARTMENT OF THE INTERIOR \\ BRUCE BABBITT, Secretary}

U.S. GEOLOGICAL SURVEY

Charles G. Groat, Director

The use of firm, trade, and brand names in this report is for identification purposes only and does not constitute endorsement by the U.S. Geological Survey.

For additional information write to:

District Chief

U.S. Geological Survey

Water Resources Division

520 N. Park Avenue, Suite 221

Tucson, AZ 85719-5035
Copies of this report can be purchased from:

U.S. Geological Survey

Information Services

Box 25286

Federal Center

Denver, C0 80225-0046

Information about U.S. Geological Survey programs in Arizona is available online at http://az.water.usgs.gov. 


\section{CONTENTS}

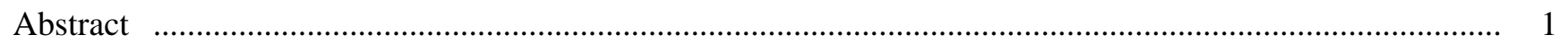

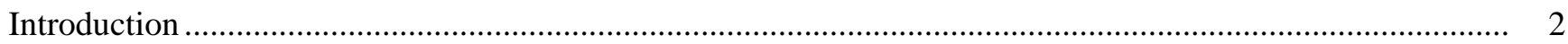

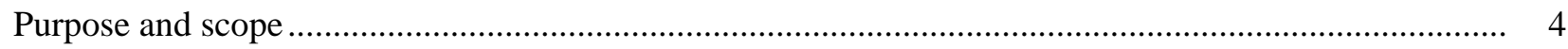

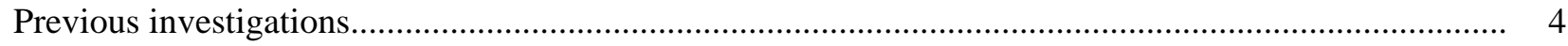

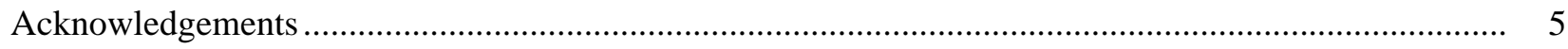

Description of the study area and historical land use of Grande Wash......................................................... 5

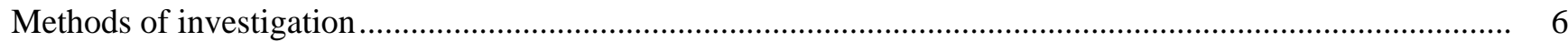

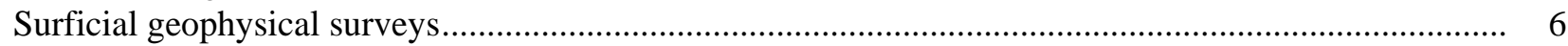

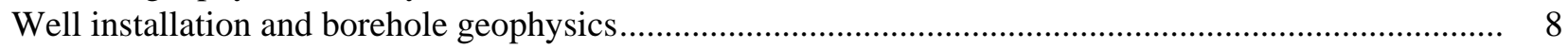

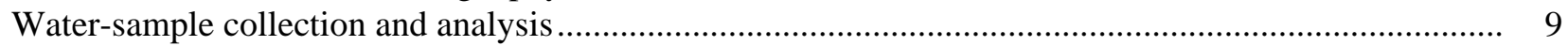

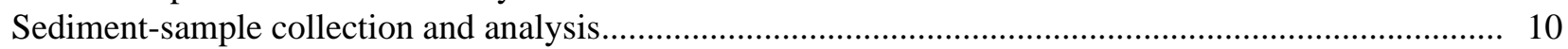

Hydrogeology

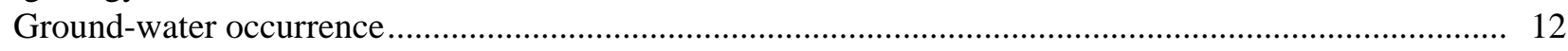

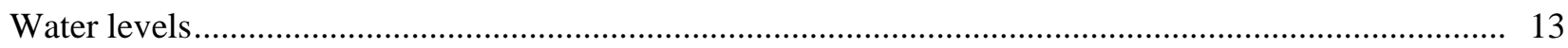

Thickness and hydraulic conductivity of the shallow aquifer and ground-water flux .......................... 17

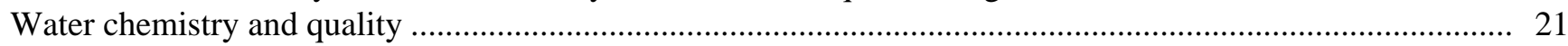

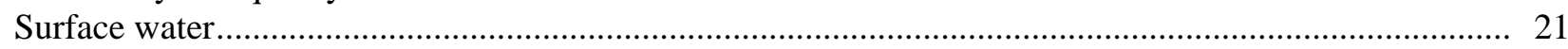

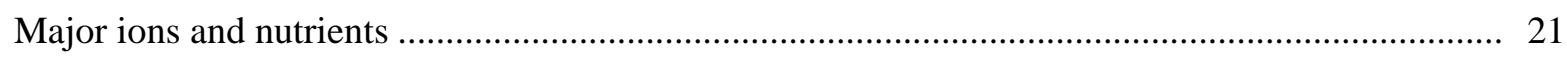

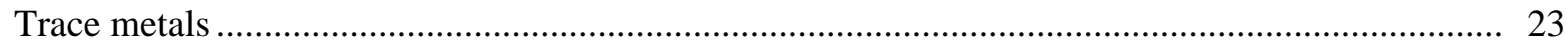

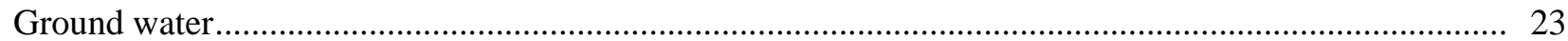

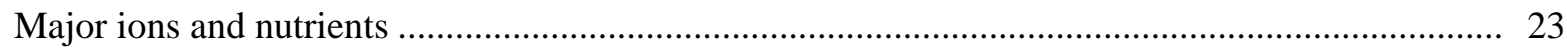

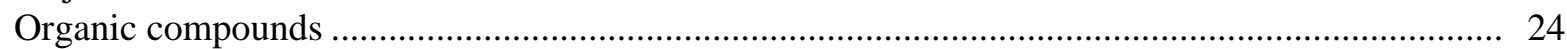

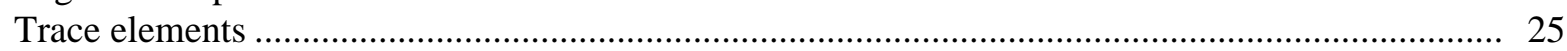

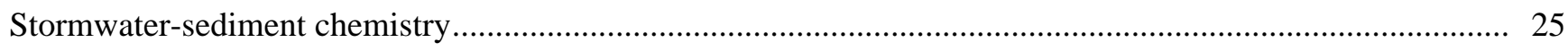

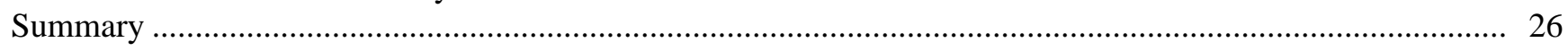

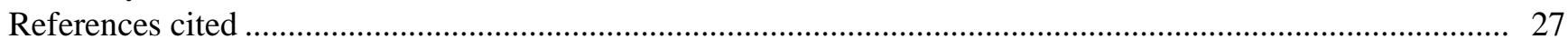

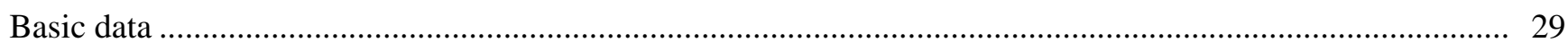




\section{FIGURES}

1. Map showing Grande Wash study area, Fort McDowell Indian Reservation, Arizona...................... 3

2. Photographs showing potential sources of contamination to ground water and surface water of Grande Wash, Fort McDowell Indian Reservation, Arizona .............................................. 4

3. Land-use map of Grande Wash, Fort McDowell Indian Reservation, Arizona ................................. 6

4. Photographs showing Seismic-refraction and electromagnetic surveys.

A. Shallow seismic-refraction survey using hammer for energy source ….................................... 7

B. Electromagnetic survey using EM34-3 instrument …........................................................... 7

C. Lowering explosives charge for seismic-refraction survey ...................................................... 7

5. Map showing locations of surface-and borehole-geophysics sites; ground-water, surfacewater, and sediment sampling sites; and monitor wells; Grande Wash, Fort McDowell

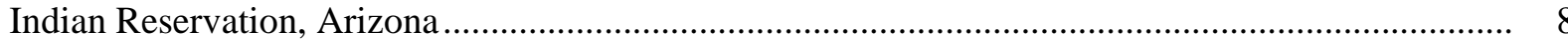

6. Map showing generalized surficial geology within and adjacent to the study area, Fort McDowell Indian Reservation, Arizona

7. Photograph showing recent stream-channel deposits in the main channel of Grande Wash, Fort McDowell Indian Reservation, Arizona

8. Geologic section normal to Grande Wash showing ground-water mound above clay and silt unit and conductivity log for Well GWMW4, Fort McDowell Indian

Reservation, Arizona

9. Map showing altitude of the top of the clay and silt unit and altitude of the water table,

Fort McDowell Indian Reservation, Arizona.

10. Hydrologic section showing altitude of the land surface and water table, water levels in nested monitor wells, and contact between coarse-grained deposits and the clay and silt unit, Grande Wash, Fort McDowell Indian Reservation, Arizona

11. Graphs showing water levels in selected wells, daily rainfall during period of study, and relation of rainfall and water-level change at well GWMW5, Grande Wash, Fort McDowell Indian Reservation, Arizona

12. Graph showing water level in well GWMW10, Grande Wash, Fort McDowell Indian Reservation, Arizona, and stage of the Verde River near Scottsdale during period of study.....

13. Electromagnetic model of Grande Wash along main-channel profile

14. Map showing estimated average saturated thickness of coarse-grained deposits,

Grande Wash, Fort McDowell Indian Reservation, Arizona

15. Trilinear diagram showing relative proportions of major ions for surface-water and ground-water samples, Grande Wash, Fort McDowell Indian Reservation, Arizona

16. Graph showing concentration of selected constituents at surface-water sites in relation to time since peak flow and to rainfall, Grande Wash, Fort McDowell Indian Reservation, Arizona 


\section{TABLES}

1. Depths of investigation for EM31 and EM34-3 at various coil spacings and orientations

2. Model results of selected electromagnetic soundings adjacent to the main channel of

Grande Wash, Fort McDowell Indian Reservation, Arizona ....................................................... 18

3. Model results of seismic-refraction data, Grande Wash, Fort McDowell Indian

Reservation, Arizona

4. Summary of information from monitor-well logs, Fort McDowell Indian

Reservation, Arizona

5. Concentrations of selected constituents in ground water below Grande Wash,

Fort McDowell Indian Reservation, Arizona

6. Volatile organic compounds (VOCs) detected in ground water, Grande Wash,

Fort McDowell Indian Reservation, Arizona

7. Water-chemistry and stormwater-sediment chemistry data, Grande Wash,

Fort McDowell Indian Reservation, Arizona .

\section{CONVERSION FACTORS AND VERTICAL DATUM}

\begin{tabular}{|c|c|c|}
\hline Multiply & By & To obtain \\
\hline inch (in) & 2.54 & centimeter \\
\hline inch (in) & 25.4 & millimeter \\
\hline foot $(\mathrm{ft})$ & 0.3048 & meter \\
\hline mile (mi) & 1.609 & kilometer \\
\hline acre & 4,047 & square meter \\
\hline square foot $\left(\mathrm{ft}^{2}\right)$ & 0.09290 & square meter \\
\hline square mile $\left(\mathrm{mi}^{2}\right)$ & 2.590 & square kilometer \\
\hline gallon (gal) & 0.003785 & cubic meter \\
\hline million gallons (Mgal) & 3,785 & cubic meter \\
\hline acre-foot (acre-ft) & 1,233 & cubic meter \\
\hline acre-foot per day (acre-ft/d) & 0.01427 & cubic meter per second \\
\hline acre-foot per year (acre-ft/yr) & 1,233 & cubic meter per year \\
\hline foot per day $(\mathrm{ft} / \mathrm{d})$ & 0.3048 & meter per day \\
\hline cubic foot per second $\left(\mathrm{ft}^{3} / \mathrm{s}\right)$ & 0.02832 & cubic meter per second \\
\hline cubic foot per second per square mile $\left[\left(\mathrm{ft}^{3} / \mathrm{s}\right) / \mathrm{mi}^{2}\right]$ & 0.01093 & cubic meter per second per square kilometer \\
\hline cubic foot per day $\left(\mathrm{ft}^{3} / \mathrm{d}\right)$ & 0.02832 & cubic meter per day \\
\hline gallon per day (gal/d) & 0.003785 & cubic meter per day \\
\hline foot per day (ft/d) & 0.3048 & meter per day \\
\hline foot per mile $(\mathrm{ft} / \mathrm{mi})$ & 0.1894 & meter per kilometer \\
\hline
\end{tabular}

Temperature in degrees Celsius $\left({ }^{\circ} \mathrm{C}\right)$ may be converted to degrees Fahrenheit $\left({ }^{\circ} \mathrm{F}\right)$ as follows:

$$
{ }^{\circ} \mathrm{F}=1.8\left({ }^{\circ} \mathrm{C}\right)+32
$$




\section{ABBREVIATED WATER-QUALITY UNITS}

Chemical concentration and water temperature are given only in metric units. Chemical concentration in water is given in milligrams per liter $(\mathrm{mg} / \mathrm{L})$ or micrograms per liter $(\mu \mathrm{g} / \mathrm{L})$. Milligrams per liter is a unit expressing the solute mass (milligrams) per unit volume (liter) of water. One thousand micrograms per liter is equivalent to 1 milligram per liter. For concentrations less than 7,000 milligrams per liter, the numerical value is about the same as for concentrations in parts per million. Specific conductance is given in microsiemens per centimeter at 25 degrees Celsius $\left(\mu \mathrm{S} / \mathrm{cm}\right.$ at $\left.25^{\circ} \mathrm{C}\right)$. Chemical concentration in sediment is given in grams per kilogram $(\mathrm{g} / \mathrm{kg})$, micrograms per gram $(\mu \mathrm{g} / \mathrm{g})$, milligrams per kilogram $(\mathrm{mg} / \mathrm{kg})$, or micrograms per kilogram $(\mu \mathrm{g} / \mathrm{kg})$. Grams per kilogram is equal to parts per thousands (ppt). Milligrams per kilogram and micrograms per gram are equal to parts per million (ppm). Micrograms per kilogram are equal to parts per billion (ppb).

\section{VERTICAL DATUM}

Sea level: In this report, "sea level" refers to the National Geodetic Vertical Datum of 1929 (NGVD of 1929)--a geodetic datum derived from a general adjustment of the first-order level nets of both the United States and Canada, formerly called Sea Level Datum of 1929.

Altitude, as used in this report, refers to distance above or below sea level. 


\title{
Hydrogeology, Water Quality, and Stormwater-Sediment Chemistry of the Grande Wash Area, Fort McDowell Indian Reservation, Maricopa County, Arizona
}

\author{
By John P. Hoffmann
}

\section{Abstract}

Grande Wash is a tributary of the Verde River and drains an area of 13 square miles within the McDowell Mountains and the Town of Fountain Hills in Central Arizona. The wash enters the Fort McDowell Indian Reservation at the eastern boundary of Fountain Hills and is incised in coarsegrained alluvium that is contiguous with the alluvial aquifer along the Verde River. The aquifer is used by the Fort McDowell Indian Community and the City of Phoenix for municipal water supplies. Episodic flows in Grande Wash, in response to storms, carry potentially hazardous runoff from Fountain Hills onto the reservation. Additional potential hazards to ground water include contamination from a wastewatertreatment plant located less than 1 mile upstream from the reservation boundary, and from a landfill and a cement-processing plant immediately adjacent to the main channel of the wash.

Coarse-grained deposits in Grande Wash also include recent stream-channel deposits, soil backfill, landfill material, and the upper coarse-grained layer of basin-fill sediments. Surface-geophysical surveys and drilling indicated that the coarse-grained deposits are less than 60-feet thick along the wash and in adjacent areas within the reservation, and are underlain by a thick clay and silt unit, the base of which is below the bottom of the deepest monitor well (317 feet below land surface). The coarse-grained deposits form the alluvial aquifer beneath Grande Wash.

Ground water in the alluvial aquifer beneath the wash is shallow and mounded above a less permeable clay and silt unit. Depth to water in the aquifer ranges from 1 to 22 feet below land surface. Saturation of the coarse-grained deposits does not extend laterally for more than about 1,000 feet from the main channel of Grande Wash; the extent varies in response to recharge amounts.

Flux of ground water through the alluvial aquifer beneath the wash is toward the Verde River and is estimated to be about 8,000 cubic feet per day (about 0.2 acre-feet per day). The flow rate is four orders of magnitude less than the flow rate in the Verde River. Vertical flux of ground water through the underlying clay and silt unit is estimated to be 7,000 cubic feet per day ( 0.17 acre-feet per day). The volume of ground water in storage in the alluvial aquifer beneath Grande Wash is estimated to be about 5.6 million cubic feet (129 acre-feet).

Concentrations of dissolved inorganic constituents in ground water and surface water are high relative to concentrations found in the regional aquifer in surrounding areas and are indicative of salts that can be expected to be mobilized by runoff in the drainage area. Concentrations of nitrate, chloride, and sulfate are near U.S. Environmental Protection Agency Primary or Secondary Drinking-Water Regulations. 
Concentrations of arsenic, antimony, and strontium are below drinking-water standards but can be attributed to geologic deposits in and near the study area.

Low concentrations of anthropogenic compounds, including chloroform and dichlorobromomethane, were detected. These compounds are disinfection by-products of chlorinated water.

Eight pesticide compounds were detected in the surface water, and two pesticide compounds were detected in the ground water. Pesticide concentrations were below U.S. Environmental Protection Agency Maximum Contaminant Levels. Several other organic anthropogenic compounds that probably originated from commercial activities in the area were detected but at concentrations below laboratory calibration standards.

Concentrations of trace metals in the stormwater sediment collected from the sediment retention basin in the lowest part of the wash were low and several were below the laboratory's detection limits. Concentrations of most organic compounds in the stormwater sediment were below detection limits. Organic compounds present at concentrations above detection limits were p-cresol and two phthalate esters-bis (2-ethylhexyl) phthalate and dibutyl phthalate. $\mathrm{P}$-cresol is used in pesticides or in disinfectants and deodorizers, and phthalate esters are commonly used in plastics, hydraulic fluid, and electric capacitors.

\section{INTRODUCTION}

Grande Wash is an ephemeral tributary of the Verde River that traverses the west-central part of the Fort McDowell Indian Reservation (fig. 1). The wash originates on the east flank of the McDowell Mountains and drains eastward to the Verde River. The Verde River provides recreational, agricultural, and domestic-water supplies to the Fort McDowell Indian Community. In addition, the Verde River sustains aquatic life and dense riparian vegetation on the adjacent flood plain that provides habitat for wildlife. Grande Wash (known as Ashbrook Wash west of the reservation) drains an area of about $13 \mathrm{mi}^{2}$ within the McDowell Mountains and the Town of Fountain Hills and crosses about $1.5 \mathrm{mi}$ of reservation land before joining the Verde River. The wash, and areas immediately adjacent to it, have been used by the Fort McDowell Indian Community for sand and gravel mining, commercial storage, industrial facilities, and landfills. The wash also has been used as a discharge site for the Fountain Hills wastewater-treatment plant, which is about 1 mi up gradient from the reservation boundary.

The population of the Fort McDowell Indian Community increased from 349 in 1980 to 844 in 1995. Located just west of the reservation, the Town of Fountain Hills also is a rapidly growing community that had an average annual growth rate of 13.7 percent between the years of 1980 and 1990 (Fountain Hills Chamber of Commerce, written commun., 1997). The population in 1980 was 2,772 and the projected population for the year 2000 is 18,715 . The growing population has resulted in increased urbanization of the Grande Wash drainage area.

The growing population and increasing development within and surrounding the Fort McDowell Indian Reservation have led to community concerns about the hydrologic conditions of Grande Wash. One concern is the quantity and quality of ground water available in the shallow alluvial aquifer beneath the wash. Potential sources of groundwater and surface-water contamination include landfill material adjacent to Grande Wash, stormwater runoff from the Town of Fountain Hills, and discharge from the wastewater treatment plant and from a cementprocessing plant on the reservation near the wash (fig. 2). Another concern is that surface water entering the reservation in Grande Wash could adversely affect the quality of ground water withdrawn from watersupply wells of the Fort McDowell Community and the City of Phoenix. The U.S. Geological Survey (USGS), in cooperation with the Fort McDowell Yavapai Nation, studied the hydrology of Grande Wash to address these concerns. 


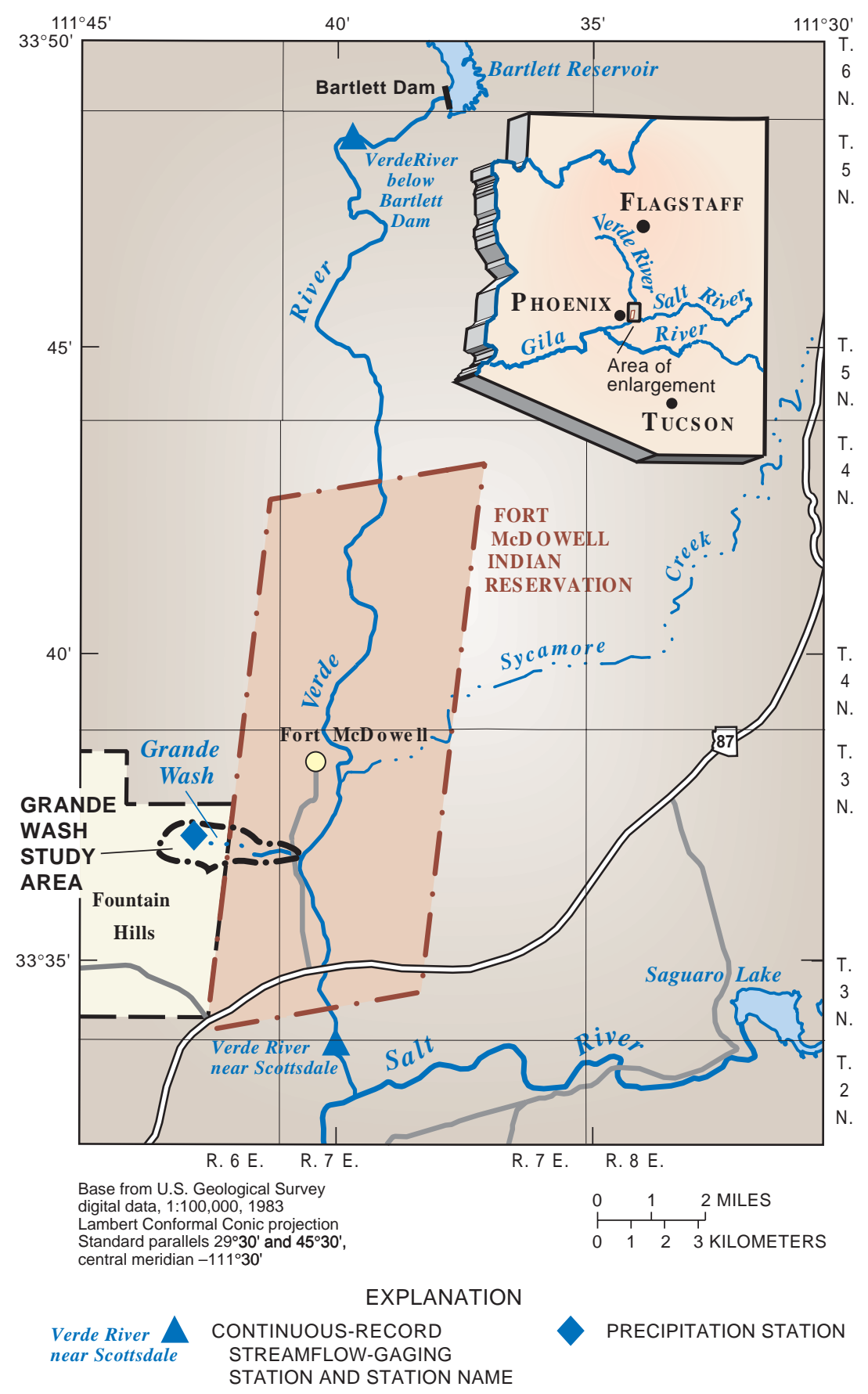

Figure 1. Grande Wash study area, Fort McDowell Indian Reservation, Arizona. 


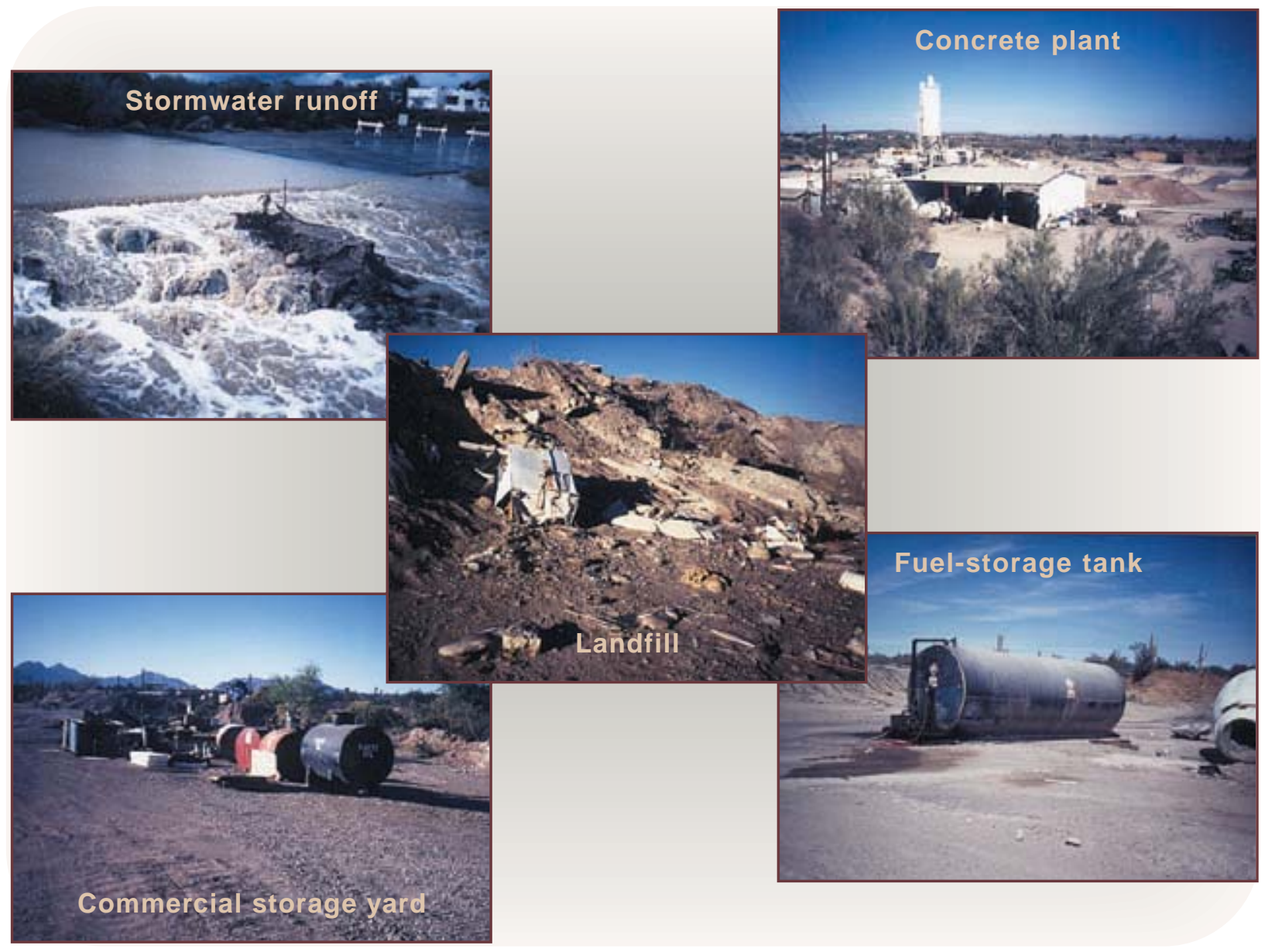

Figure 2. Potential sources of contamination to ground water and surface water of Grande Wash, Fort McDowell Indian Reservation, Arizona.

\section{Purpose and Scope}

The purpose of this study was to determine (1) the horizontal and vertical extent of the shallow alluvial aquifer beneath Grande Wash; (2) the directions of ground-water flow in the aquifer; (3) the quantity and quality of ground water in storage in the aquifer; (4) the quality of the surface water entering the reservation in Grande Wash; and (5) the chemistry of the stormwater sediment in Grande Wash. Data collection efforts in this study were concentrated in an approximately 2-mile reach along and adjacent to Grande Wash from about $1,000 \mathrm{ft}$ west of the reservation boundary in the Town of Fountain Hills to the confluence with the Verde River. This report describes the hydrogeology of the shallow aquifer beneath Grande Wash within the reservation. A conceptual model of the aquifer system and movement of ground water is presented.
Quality of the surface water entering the Reservation lands in Grande Wash, quality of the ground water beneath Grande Wash, and chemistry of the stormwater sediment, also are described. The quality of surface water and ground water is assessed by comparing concentrations of constituents with the U.S. Environmental Protection Agency Primary and Secondary Drinking-Water Regulations and guidance levels.

\section{Previous Investigations}

No report on the hydrogeology of Grande Wash has been published to date. The earliest geohydrologic investigation of the area was by McDonald and Padgett (1945). They described the geology and ground-water 
resources of the Verde River Valley below Bartlett Dam with the purpose of determining the adequacy of ground water from the alluvium beneath the Verde River for municipal supply for the City of Phoenix. Wilson and others (1957) mapped the geology of the watershed. Water-resources in the area of Sycamore Creek, a tributary of the Verde River on the east side of the Community lands were studied, by Thomsen and Dennis (1963), Schumann (1967), and Thomsen and Schumann (1968). Maps showing ground-water conditions in the area were published by Ross (1977), Reeter and Remick (1986), and Hammett and Herther (1995). Several consultant reports describe potential environmental impacts to Grande Wash or nearby areas. The reports include SCS Engineers, 1996a and 1996b; and Fluor Daniel GTI, written commun., 1996.

\section{Acknowledgements}

Darrell Russell and Marilyn Ethelbah of the Fort McDowell Environmental Department and Wayne Miller of Fort McDowell Public Works provided logistical support for field operations. Paul Carney of the Fort McDowell Farm provided backhoe operators for field operations. Michael Lejero of the Fort McDowell Engineering Department provided personnel to assist with seismic field activities.

\section{DESCRIPTION OF THE STUDY AREA AND HISTORICAL LAND USE OF GRANDE WASH}

The study area (approximately $2 \mathrm{mi}^{2}$ ) is located on and adjacent to the Fort McDowell Indian Reservation about 23 mi northeast of Phoenix (fig. 1). Grande Wash is a tributary to the Verde River and has a drainage area of about $13 \mathrm{mi}^{2}$. The elevation of the wash ranges from $1,380 \mathrm{ft}$ where it joins the Verde River to $1,520 \mathrm{ft}$ at the west boundary of the reservation. Surface-water flows within the wash occur only in response to storms and typically last for a period of a few hours after the storm. Spring discharge (ground-water seepage) within the wash also occurs in response to storms; however, spring discharge may continue for as long as several weeks following the storm. The area has an arid climate; average annual rainfall is about 8 in.
Grande Wash was mined for sand and gravel from about the mid 1980s to 1992 (Carol Nelson-Smith, Director of Land Use/Land Lease Department, Fort McDowell Indian Community, oral commun., 1997). Aerial photographs taken in 1979 show the wash in a relatively unaltered and natural condition; however, the photographs also appear to show that small-scale excavation and backfilling activities had occurred in the western part of the wash. Mining activities during the 1980s and early 1990s deepened the wash and widened it to about $1,000 \mathrm{ft}$ within the reservation (fig. 3). Presently, (1999) a berm directs the surface-water flow coming onto the reservation into a main channel along the northern edge of the excavated area. The excavated area has since been used for commercial storage, industrial facilities, and landfill (primarily construction debris and soil backfill).

Commercial storage yards were located in the western-most part of the wash and used from the late 1980s to 1996 (fig. 3). Contents in the storage yards that were potential hazards to ground water or surface water included old vehicles, above-ground fuel tanks, vehicle batteries, 55-gallon drums, and used oil filters (SCS Engineers, 1996b). The concrete company has leased the area immediately east of the former storage area since about 1986 (fig. 3). The leased area was occupied by an asphalt plant and ready-mix concrete plant from 1982 to 1986 . The concrete plant uses about 1.3 million gallons of water per month, and most of the water is used to wash cement trucks. Effluent from the concrete plant's washing area has been observed to flow into the main channel of Grande Wash by way of an open ditch. In addition, SCS Engineers (1996b) reported that several waste-oil and diesel-fuel storage tanks without secondary containment were in the leased area. According to SCS (1996b) the concrete trucks have discharged residual material in the washout areas about $1 \mathrm{mi}$ east of the leased area (fig. 3). The Grande Wash landfill has been operating since about 1988, is uncapped and graded, and the material in the landfill has been characterized as soil backfill and construction debris wastes (SCS Engineers, 1996a). Other materials such as household wastes and buried and crushed 55-gallon drums have been observed in the landfill. Thickness of fill material in the study area ranges from 4 to $35 \mathrm{ft}$. The eastern-most part of the wash is used as a sediment- and stormwater-retention basin, which contains standing water for several months of each year (fig. 3). 


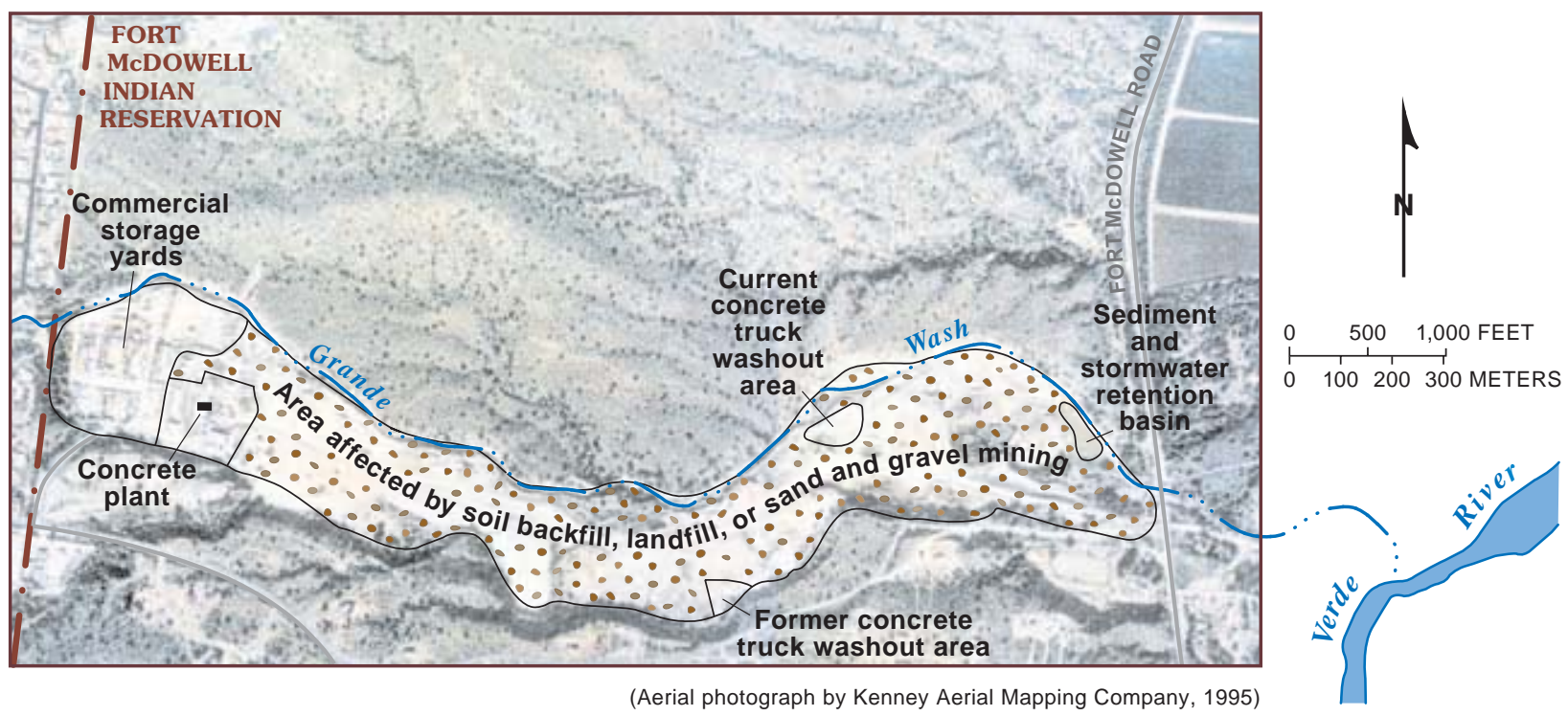

Figure 3. Land-use map of Grande Wash, Fort McDowell Indian Reservation, Arizona.

The Fountain Hills wastewater-treatment plant is on the north bank of Ashbrook Wash less than $1 \mathrm{mi}$ upgradient from the reservation boundary. The plant treats about 1.5 million gallons of water per day. Prior to 1995 , the plants effluent disposal system was at times unable to keep up with demand (Fountain Hills Sanitary District, written commun., 1996) and was the source of numerous discharges of effluent to Ashbrook Wash. Several of the discharges were documented by the Arizona Department of Environmental Quality (Leah Ganelin Gripp, Environmental Program Specialist, written commun., 1994, and M. Reza Azizi, Acting Manager, Surface Water Enforcement Unit, Water Quality Division, written commun., 1995). There have been no documented effluent discharges into Ashbrook Wash since April 1995.

\section{METHODS OF INVESTIGATION}

Because little hydrogeologic information on the Grande Wash was available, an investigative program was designed to develop information on subsurface lithology, aquifer characteristics, surface- and groundwater quality, stormwater-sediment chemistry, and potential sources of contamination to surface water and ground water. This program included surface geophysical surveys, well drilling, water-level monitoring, and water and sediment sampling and analysis. Precipitation data were collected from a rain gage in Fountain Hills for 1997-1999 (fig. 1).

\section{Surficial Geophysical Surveys}

Surface electromagnetic-induction (EM) and seismic-refraction techniques provided information about subsurface lithology and were used to determine the cross-sectional area of the unconsolidated alluvium (fig. 4). EM techniques measure the electrical conductivity (the ability of the earth to conduct the flow of an electric current) of subsurface material. Electrical methods are useful in alluvial aquifer settings because the electrical properties of sands and gravels differ from those of silts, clays, and crystalline rocks. Conductivity values for crystalline rocks and dry alluvium in the arid Southwest are low, commonly less than 10 millimhos/meter (mmhos/m). Values of saturated sand and gravel typically range from 20 to $50 \mathrm{mmhos} / \mathrm{m}$; those of saturated clay and silt commonly are about $100 \mathrm{mmhos} / \mathrm{m}$ or greater. Saturated alluvial deposits often have conductivity values of 50 to $100 \mathrm{mmhos} / \mathrm{m}$, which indicates a mixture of clay, silt, sand, and gravel. 


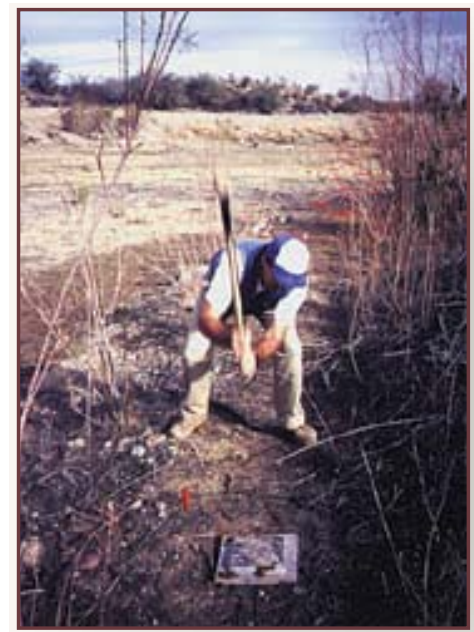

A.

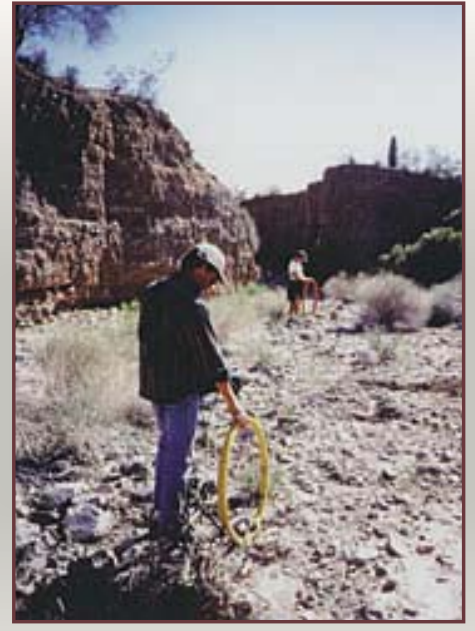

$B$.

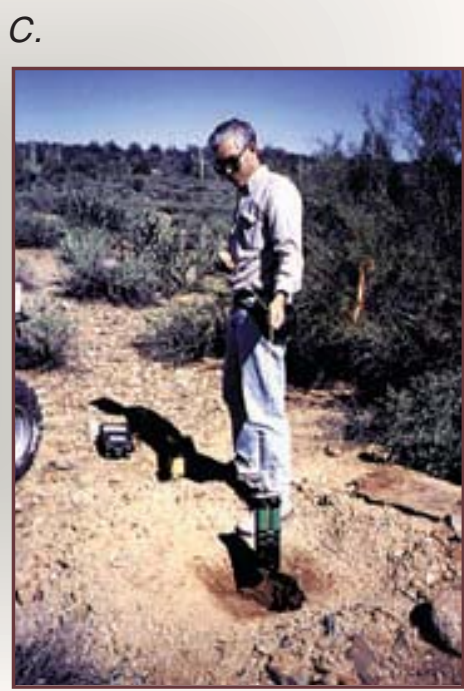

Figure 4. Seismic-refraction and electromagnetic surveys. A, Shallow seismic-refraction survey using hammer for energy source. $B$, Electromagnetic survey using EM34-3 instrument. C, Lowering explosives charge for seismic-refraction survey.

The EM method is based on an induced magnetic field and measurement of the consequent electrical response of the subsurface materials. This investigation used EM31 and EM34-3 induction tools manufactured by GEONICS LIMITED. The EM31 has a depth of investigation of about 10 to $20 \mathrm{ft}$, whereas the EM34-3 has a depth of investigation of about 25 to $200 \mathrm{ft}$ (McNeill, 1980). The equipment includes two coils; one coil transmits a primary magnetic field that induces current flow in the subsurface creating a secondary magnetic field; the second coil measures the primary and secondary magnetic fields. The ratio of the two magnetic fields is used to calculate apparent conductivity in units of millimhos per meter $(\mathrm{mmhos} / \mathrm{m})$ that is read directly from the instrument. The coil spacing for the EM31 is $12.1 \mathrm{ft}$, whereas coil spacings of 32.8, 65.6, and $131.2 \mathrm{ft}$ can be used with the EM34-3 instrument. The coils can be placed in two orientations, horizontal (vertical dipole) and vertical (horizontal dipole), at each spacing. Depth of investigation is varied by varying the spacing and orientation of the coils. Eight measurements were made using multiple coil orientations and spacings for the soundings (table 1); the larger coil spacings and vertical dipoles provide information from greater depths.
Table 1. Depths of investigation for EM31 and EM34-3 at various coil spacings and orientations

\begin{tabular}{lccc}
\hline & & \multicolumn{2}{c}{ Depth of investigation (ft) } \\
\cline { 3 - 4 } Induction tool & Coil spacing (ft) & $\begin{array}{c}\text { Vertical } \\
\text { dipole }\end{array}$ & $\begin{array}{c}\text { Horizontal } \\
\text { dipole }\end{array}$ \\
\hline EM-31 & 12.1 & 19.7 & 9.8 \\
EM34-3 & 32.8 & 49.2 & 24.6 \\
EM34-3 & 65.6 & 98.2 & 49.2 \\
EM34-3 & 131.2 & 196.9 & 98.4 \\
\hline
\end{tabular}

Electrical conductivity measurements were made with the EM-31 instrument at 88 sites along the main channel of Grande Wash, from the sediment retention basin at the east end of the wash to the west boundary of the reservation (fig. 5). Soundings were made at 23 of the 88 sites in the main channel. Electrical conductivity measurements were made at 55 sites in the excavated and backfilled area adjacent to the main channel; depth soundings were made at 7 of these sites. Two sounding sites were on the terraced alluvial deposits outside the wash. Data from selected soundings were inversely modeled for subsurface electrical layers using commercially available EMIX 34 PLUS software (Interpex Limited, 1994). 


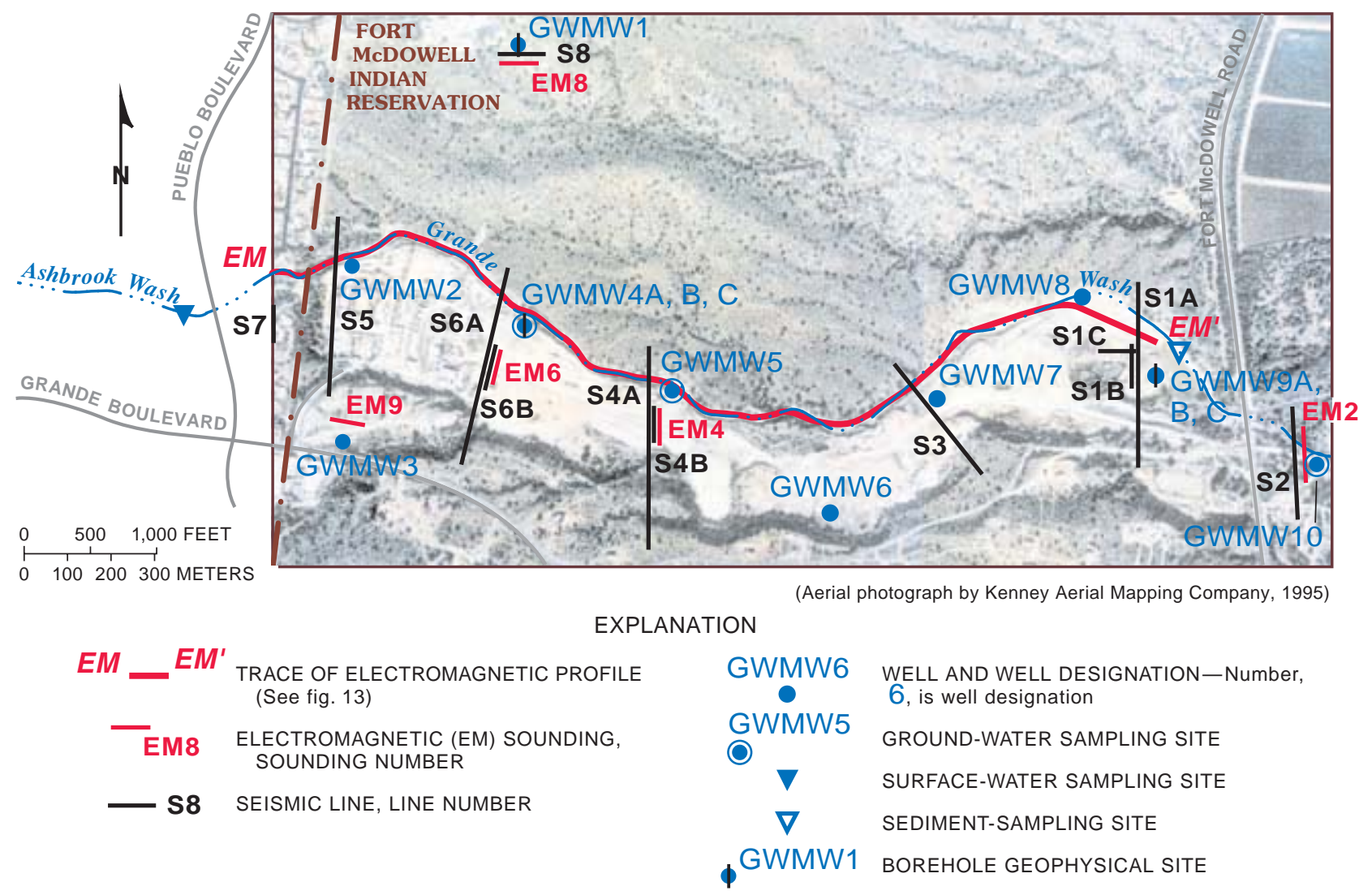

Figure 5. Locations of surface-and borehole-geophysics sites; ground-water, surface-water, and sediment sampling sites; and monitor wells; Grande Wash, Fort McDowell Indian Reservation, Arizona.

Seismic-refraction surveys identified subsurface layering. Subsurface materials tend to be more densely compacted with increasing depth; consequently, pressure waves are transmitted at higher velocities with increasing depth. The velocity contrast between layers produces a refracted pressure wave that is detected by a line of geophones laid out on land surface. Potential targets for the surveys were the tops of consolidated conglomerates or bedrock layers. The primary objective of the seismic surveys was to delineate the bottom of the alluvial aquifer. The water table also can be a good refractor if the aquifer comprises poorly consolidated sand and gravel.

Seismic-refraction surveys were conducted in eight areas (fig. 5) using two sources of energy to produce the pressure-wave signal. A sledge hammer was used as the signal source for shallow investigations (upper $100 \mathrm{ft}$ ). Explosive charges were used for the deeper investigations (to about $500 \mathrm{ft}$ ). Geophone spacings of about 10 and $40 \mathrm{ft}$ were used for the shallow and deep investigations, respectively. All deep investigations were conducted orthogonal to the wash. All but one of the shallow investigations were conducted orthogonal to the wash; one was conducted parallel to the wash. Geophone and shot-point locations were surveyed using an electronic distance meter (EDM) total station. A 24-channel digital seismograph manufactured by EG\&G Geometrics was used for the refraction surveys. Analysis of seismic-refraction data using the SIP software package (Rimrock Geophysics Inc., 1995) provided thickness and seismic velocities for various subsurface layers.

\section{Well Installation and Borehole Geophysics}

In April and May 1997, 14 monitoring wells were installed at 10 sites in and near Grande Wash (fig. 5). Well information enabled description of local geohydrologic conditions and determination of the 
directions of ground-water flow. Site selection was based on the need for spatial information on water levels and water quality in the shallow alluvial aquifer. The distribution of monitoring wells provides areal coverage of the wash within the reservation with an emphasis on wells near the main channel of the wash. Two sites outside the wash were selected to expand the areal coverage and help define the extent of the aquifer. Well depths varied from 20 to $320 \mathrm{ft}$. Nested monitor wells at two sites enabled determination of vertical water-level gradients. Water levels were monitored at all wells; selected wells were equipped with pressure transducers and thermometers to record water levels and temperatures on an hourly basis. Manual waterlevel measurements were made monthly at all wells when the recording equipment was serviced. Data are stored in the U.S. Geological Survey's Ground-Water Site Inventory System (GWSI) data base.

The three deepest (>300 ft) wells were logged using borehole geophysical tools to obtain natural gamma, resistivity, and temperature data. An elevation and precise latitude and longitude was established for each site using a total station EDM and the global positioning satellite system with a horizontal resolution of about $5 \mathrm{ft}$. The surface-geophysical data were correlated and verified with well-log information from the monitor wells.

Each well was screened with a $10-\mathrm{ft}$ section of 2-inch diameter polyvinyl chloride (PVC) slotted well screen and the screen was packed with 3/8-in. gravel. The wells were sealed with bentonite grout in the annular spaces. A bentonite grout plug also was used to isolate vertically adjacent screened intervals at nestedwell sites. All wells that penetrated saturated alluvium or landfill material were developed using compressed air.

\section{Water-Sample Collection and Analysis}

Grande Wash flows during periods of high rainfall; otherwise the wash is dry. Flows typically persist for a few hours after the end of rainfall. During the study period, flow in the wash occurred about nine times; samples were collected during four of these flows. All surface-water samples were collected as flow was receding (from 2 to 15 hours after peak flow). Rainfall that resulted in flow in the wash ranged from 0.2 to 1.61 in. at the nearby Fountain Hills Fire Station rain gage (fig. 1). The multiple sampling rounds enabled evaluation of changes in surface-water chemistry and quality due to differences in rainfall amount and (or) time between rainfall and sample collection.

Surface water samples were collected four times between January 1997 and July 1999. Surface-water samples collected approximately $1,000 \mathrm{ft}$ west of the Reservation boundary (fig. 5), were composited using a churn splitter within a few hours after the end of storms. Bicarbonate and carbonate concentrations were determined in the field by incremental titration of filtered samples with dilute sulfuric acid. Samples for dissolved-ion analyses were filtered using a 0.45-micrometer membrane filter. Plastic amber bottles were used to collect samples for the determination of nutrients. Samples for dissolved-metal analyses were filtered and preserved with concentrated nitric acid. Samples for volatile organic compound (VOC) analyses were collected in glass amber vials and bottles with air excluded and preserved with ultra-pure hydrochloric acid. Pesticide samples were collected in baked-glass amber bottles. When possible, field measurements of dissolved-oxygen concentration, $\mathrm{pH}$, specific conductance, and temperature were measured at the point where grab samples were collected. All surface-water samples were chilled after collection and sent to the USGS National Water-Quality Laboratory in Arvada, Colorado, within 24 hours of collection.

Ground water was analyzed for major ions, nutrients, selected trace metals, and organic compounds. In this report, the term "metals" is used to denote metals and metalloids.

Ground-water samples were collected after at least three casing volumes of water were removed from the well using a submersible pump. Pumping was held constant at 1 gallon per minute or less during sample collection. The samples were filtered and preserved as described above. All sampling and filter equipment was rinsed thoroughly with water from the pumped well before sample collection. Samples were collected when the specific conductance, temperature, $\mathrm{pH}$, and dissolved oxygen did not vary by more than 5 percent between measurements made at 5-minute intervals. Samples were collected from wells GWMW4A, GWMW5, and GWMW10 seven times between July 1997 and September 1999. Collection of samples from other wells was attempted; however, because of the limited saturated thickness of the aquifer, these wells went dry before three casing volumes were pumped from the well or before the temperature, $\mathrm{pH}$, dissolved oxygen, or specific conductance had 
stabilized. Wells GWMW4A, GWMW5, and

GWMW10 are completed in the thickest parts of the coarse-grained deposits. Wells GWMW4A and GWMW5 penetrate landfill material. All ground-water samples were chilled after collection and sent to the USGS National Water-Quality Laboratory in Arvada, Colorado, within 24 hours of collection.

Surface-water and ground-water samples were compared to the Primary and Secondary-Drinking Water Regulations, Health Advisories, and contaminant candidate list of the U.S. Environmental Protection Agency (USEPA) for a general assessment of water quality. Primary Drinking-Water Regulations include Maximum Contaminant Levels (MCLs) that are enforceable standards and treatment techniques that are required for concentrations of certain constituents that exceed action levels. Secondary Drinking-Water Regulations include Secondary Maximum Contaminant Levels (SMCLs) that are nonenforceable guidelines based on the aesthetic properties of drinking water. Health advisories provide acceptably safe levels of exposures to contaminants in drinking water on the basis of health risks. Contaminant candidates are constituents that are being evaluated for possible future regulation by the USEPA.

\section{Sediment-Sample Collection and Analysis}

A bed-sediment sample was collected in July 1998 from the stormwater- and sediment-retention basin (fig. 5) and analyzed to determine the chemistry of sediment associated with stormwater runoff. Guidelines used for collecting bed-sediment samples are described in Shelton and Capel (1994). In summary, one part of the sample was sieved using native water to obtain the fraction of the sample less than 63 micrometers, which has the largest sorptive capacity (Horowitz and Elrick, 1987). This fraction was collected with plastic spoons and teflon sieves, and was analyzed for selected metals, chemical-oxygen demand, nutrients, and total and inorganic carbon. A coarser fraction was collected with 2.0-millimeter stainless steel sieves and was analyzed for selected organic constituents, pesticides, and base-neutral-acid compounds. Bed-sediment samples were analyzed by the Geologic Division of the USGS in Denver, Colorado.

\section{HYDROGEOLOGY}

The Town of Fountain Hills, the Fort McDowell Indian Reservation, and Grande Wash are in the lower Verde River Valley (fig. 6), which is a broad alluvial basin within the Basin and Range physiographic province. Basins within this province are bounded by steep, fault-block mountains (Fenneman, 1931). The reservation lies on an alluvial plain that is almost completely surrounded by mountains composed primarily of granitic, metamorphic, and volcanic rocks (Reeter and Remick, 1986).

Ground water in the regional aquifer occurs in the basin-fill deposits and Verde River stream alluvium. The basin-fill sediments underlying Grande Wash drainage basin are unconsolidated to consolidated sediments of Quaternary and late Tertiary age that are as much as several hundred feet thick (Wilson and others, 1957). The Quaternary basin-fill sediments consist of sand and gravel interbedded with clay and silt (Wilson and others, 1957). The interbedded clay and silt layers are inches to several hundreds of feet thick. Conglomerate of late Tertiary age underlies the unconsolidated Quaternary deposits at various depths. The unconsolidated basin fill and conglomerate generally are thinner near the McDowell and Mazatzal Mountains at the perimeter of the Verde River Basin (fig. 6) and thicken to several hundreds of feet near the Verde River toward the center of the basin.

The component of interbedded clay and silt layers also tends to be greater toward the center of the basin. The basin-fill deposits unconformably overlie crystalline bedrock of Precambrian age. Ground-water development in the Verde River Basin has not been extensive and little is known about the hydrogeology in the area. The water-table elevation in the basin-fill deposits below the Town of Fountain Hills was about $1,330 \mathrm{ft}$ in 1983 on the basis of water levels from three wells (Reeter and Remmick, 1986). Water-level data, however, were insufficient to determine flow directions. Water-table elevations in the Verde River stream alluvium within the Fort McDowell Indian Reservation generally are within a few feet of the river's elevation (Marilyn Ethelbah, Water Quality Specialist, Fort McDowell Environmental Department, written commun., 1997). 


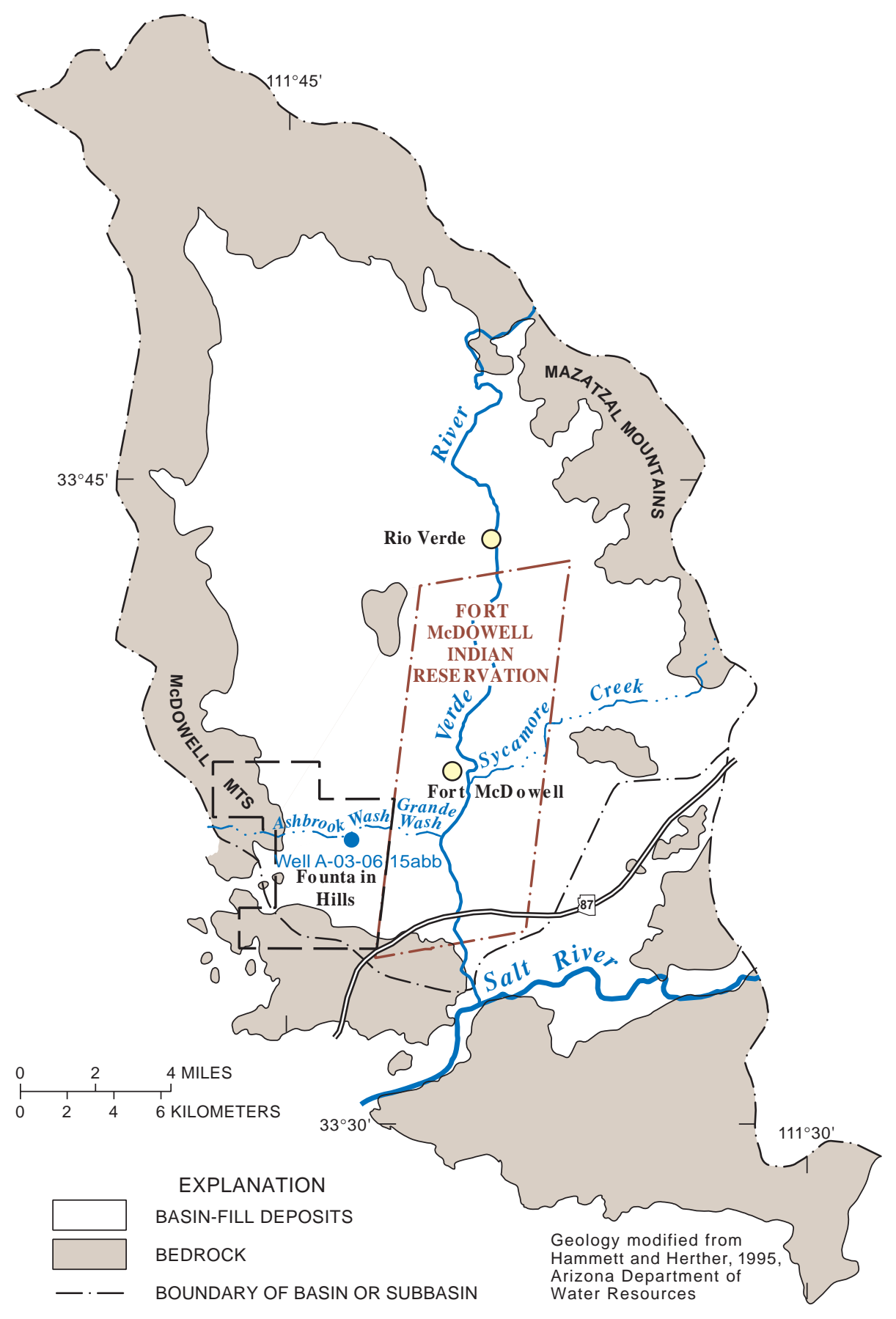

Figure 6. Generalized surficial geology within and adjacent to the study area, Fort McDowell Indian Reservation, Arizona. 
A thin veneer of recent sand, gravel and boulder stream-channel deposits overlie the basin-fill sediments in the main channel of Grande Wash (fig. 7). About 4 to about $35 \mathrm{ft}$ of unconsolidated landfill materials overlie the basin-fill sediments in areas previously mined for sand and gravel (fig. 2; SCS Engineers, 1996a). For the purposes of this report, the stream-channel deposits, landfill material, and upper coarse-grained layer of basin-fill sediments are referred to collectively as the coarse-grained deposits. These deposits form the shallow alluvial aquifer beneath and adjacent to Grande Wash.

At the confluence of the wash and the Verde River, the sand and gravel deposits underlying Grande Wash join similar deposits that underlie the Verde River. Water-supply wells for the Fort McDowell Indian clay and silt unit are less than $60 \mathrm{ft}$ thick and are typically less than $30 \mathrm{ft}$ thick in or immediately
Community and the City of Phoenix along the west bank of the river in the area of the confluence are completed in the Verde River stream alluvium.

\section{Ground-Water Occurrence}

Ground water within the study area occurs in the coarse-grained deposits (shallow alluvial aquifer) and the clay and silt unit. Well logs and surface-geophysical data indicate that the ground water in the coarse grained deposits is mounded above the clay and silt unit throughout the study area. The base of the clay and silt unit is below the bottom of the deepest monitor well ( $317 \mathrm{ft}$ below land surface). On the basis of well-log information, the coarse-grained deposits overlying the adjacent to the wash. In some areas, the main channel of Grande Wash is incised into the clay and silt unit.

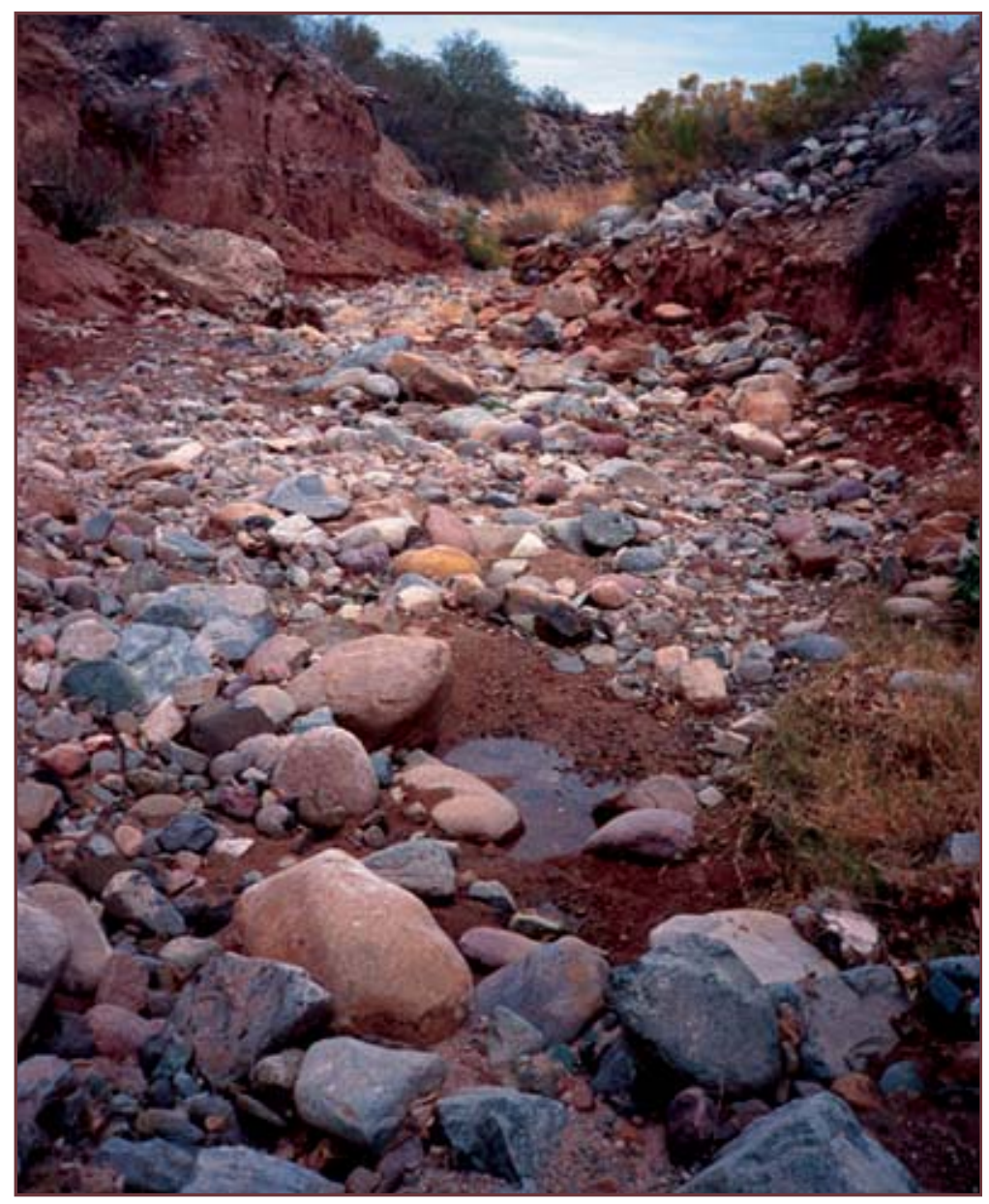

Figure 7. Recent stream-channel deposits in the main channel of Grande Wash, Fort McDowell Indian Reservation, Arizona. 
Small springs and seeps are typically associated with these areas. The saturated part of the coarse-grained deposits extends laterally to a maximum of about $1,000 \mathrm{ft}$ from the main channel, as monitor wells farthest from the wash usually are dry (fig. 8). Water levels in wells vary in response to recharge from infiltration of water from storm-flows.

\section{Water Levels}

Depth to ground water in the coarse-grained alluvium ranges from 1 to $22 \mathrm{ft}$ below land surface. Water level elevations in the monitor wells completed in the coarse-grained deposits vary from $1,381 \mathrm{ft}$ in well GWMW10 to $1,501 \mathrm{ft}$ in well GWMW2.
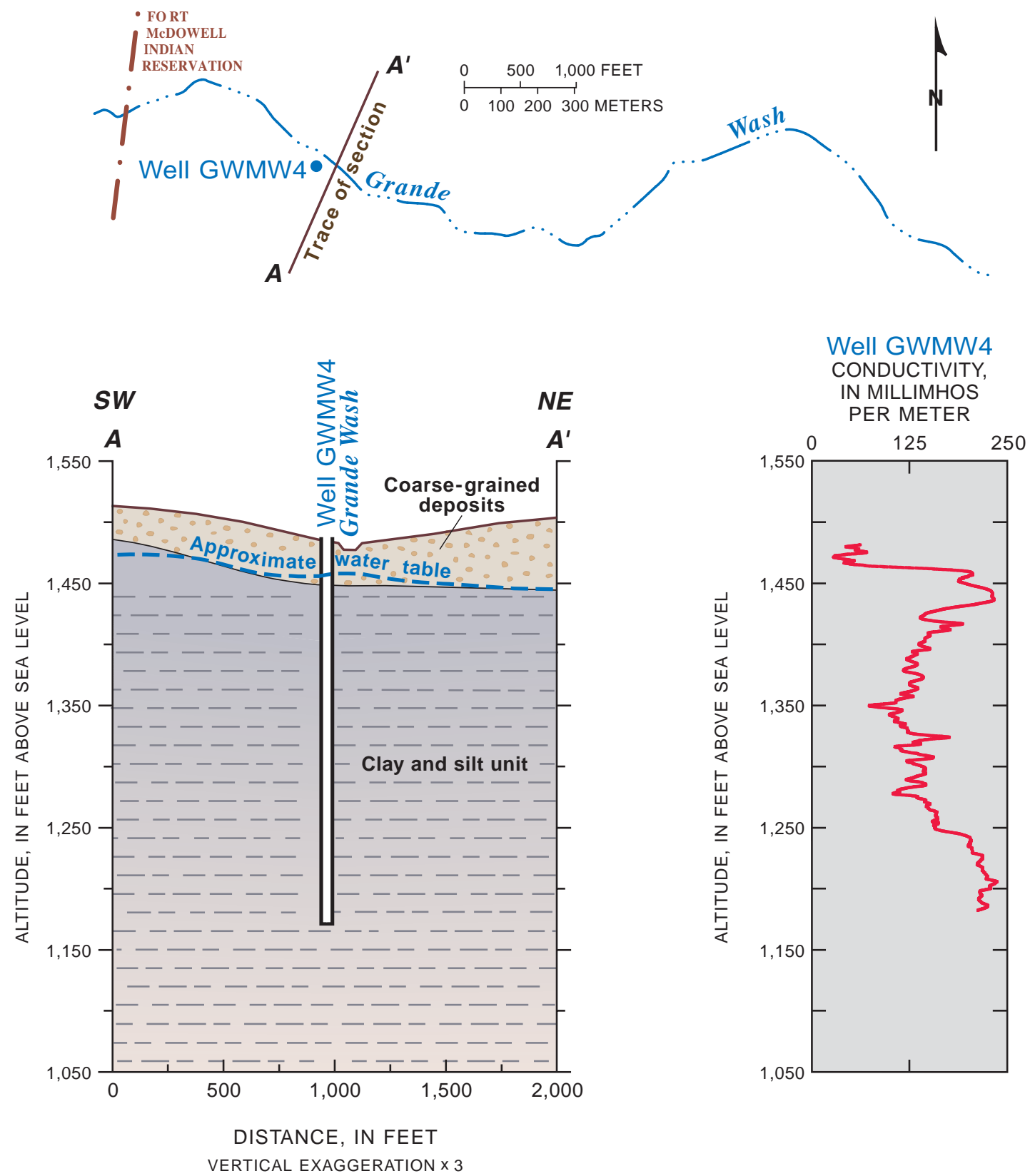

Figure 8. Geologic section normal to Grande Wash showing ground-water mound above clay and silt unit and conductivity log for Well GWMW4, Fort McDowell Indian Reservation, Arizona. See figure 14. 
A water-table contour map of the study area is shown in figure 9 and is based on water-levels measured on November 26, 1997. Water-level contours indicate that ground-water flows in the direction of surface-water flow, toward the Verde River, and the water table has a hydraulic gradient of $0.02 \mathrm{ft} / \mathrm{ft}$ (fig. 9). Water levels in the nested wells indicate a downward vertical gradient of $0.18 \mathrm{ft} / \mathrm{ft}$ from the coarse-grained deposits to the underlying clay and silt unit (fig. 10).

Water levels in wells completed in the coarsegrained deposits varied by as much as $6 \mathrm{ft}$ during the period of study and were highest in January, February, and March 1998 during periods of greatest rainfall (fig. 11). Although flow in Grande Wash is not gaged, the periods of greatest rainfall tend to produce the largest surface flows within the main channel.

Hydrographs of wells GWMW4A and GWMW5 (both instrumented with pressure transducers) indicate water levels in these wells rise rapidly in response to rainfall.
Water-level rises associated with rainfall, measured in well GWMW5, correlated with the amount of rain during the storm (correlation coefficient $(r)$ of $0.90\left(\mathrm{r}^{2}=0.81\right)$, fig. 11). There were an additional 10 periods of rainfall that did not significantly affect the water level; the greatest rainfall amount during one period was 0.32 in. All rapid water-level rises in wells GWMW4A and GWMW5 can be attributed to rainfall that resulted in flow in Grande Wash. The water-level responses to rainfall indicates an efficient hydraulic connection between the surface water in Grande Wash and ground water in the coarse-grained deposits, and that recharge occurs rapidly. Water levels declined during subsequent dry periods as ground water drained toward the Verde River. The water level in well GWMW10, which is located about $870 \mathrm{ft}$ east of the Verde River, responded primarily to the changing stage of the Verde River from May until December 1997.

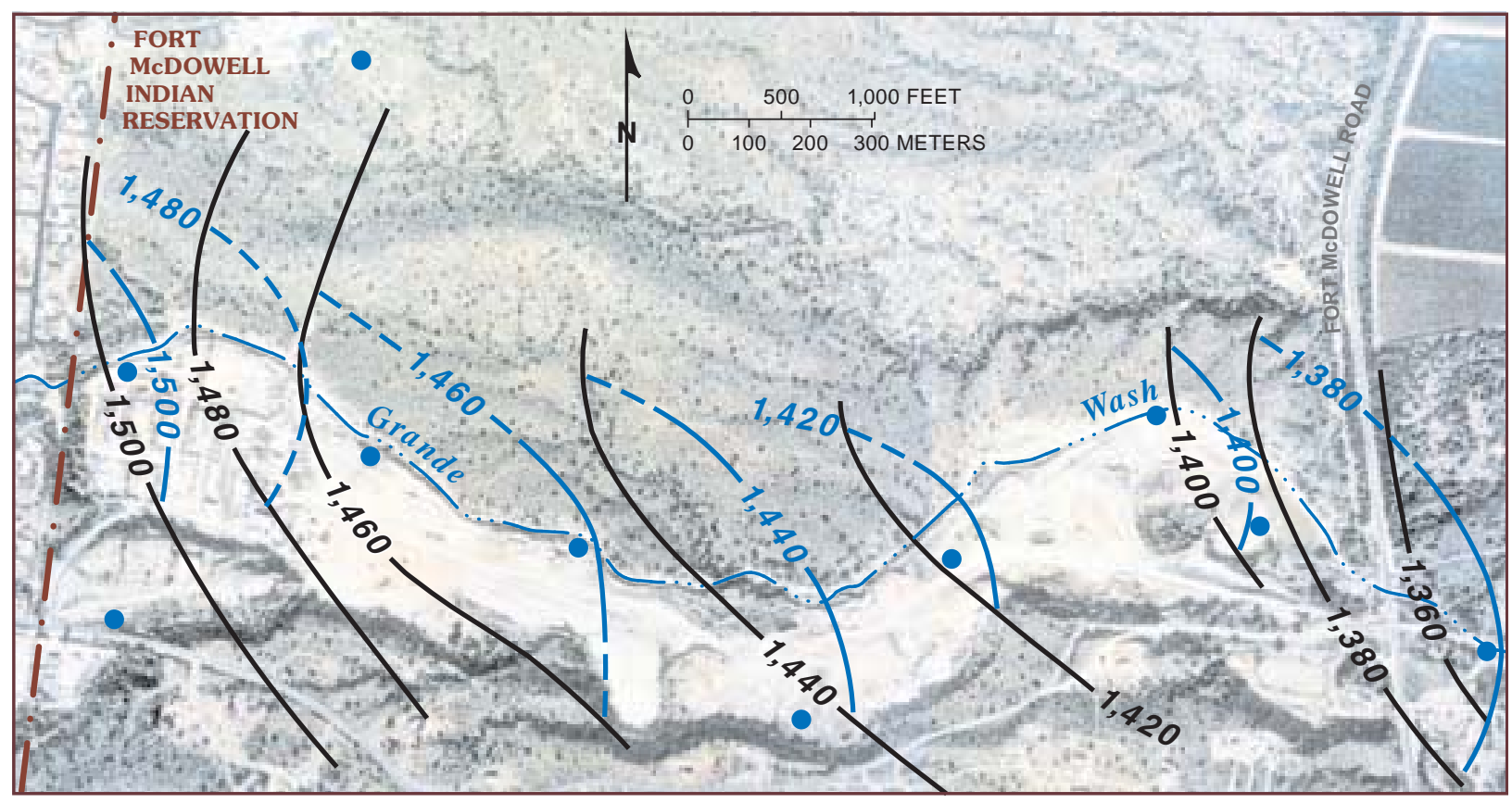

EXPLANATION

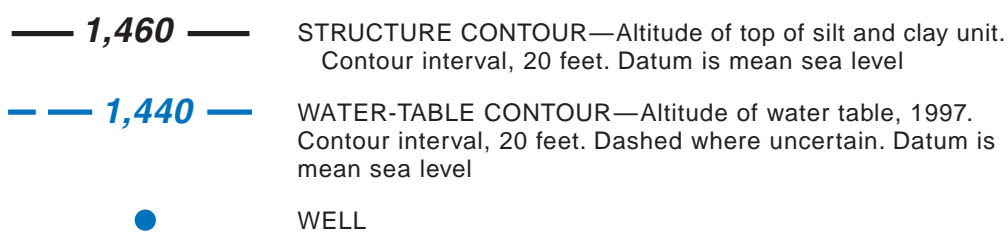

Figure 9. Altitude of the top of the clay and silt unit and altitude of the water table, Fort McDowell Indian Reservation, Arizona. 


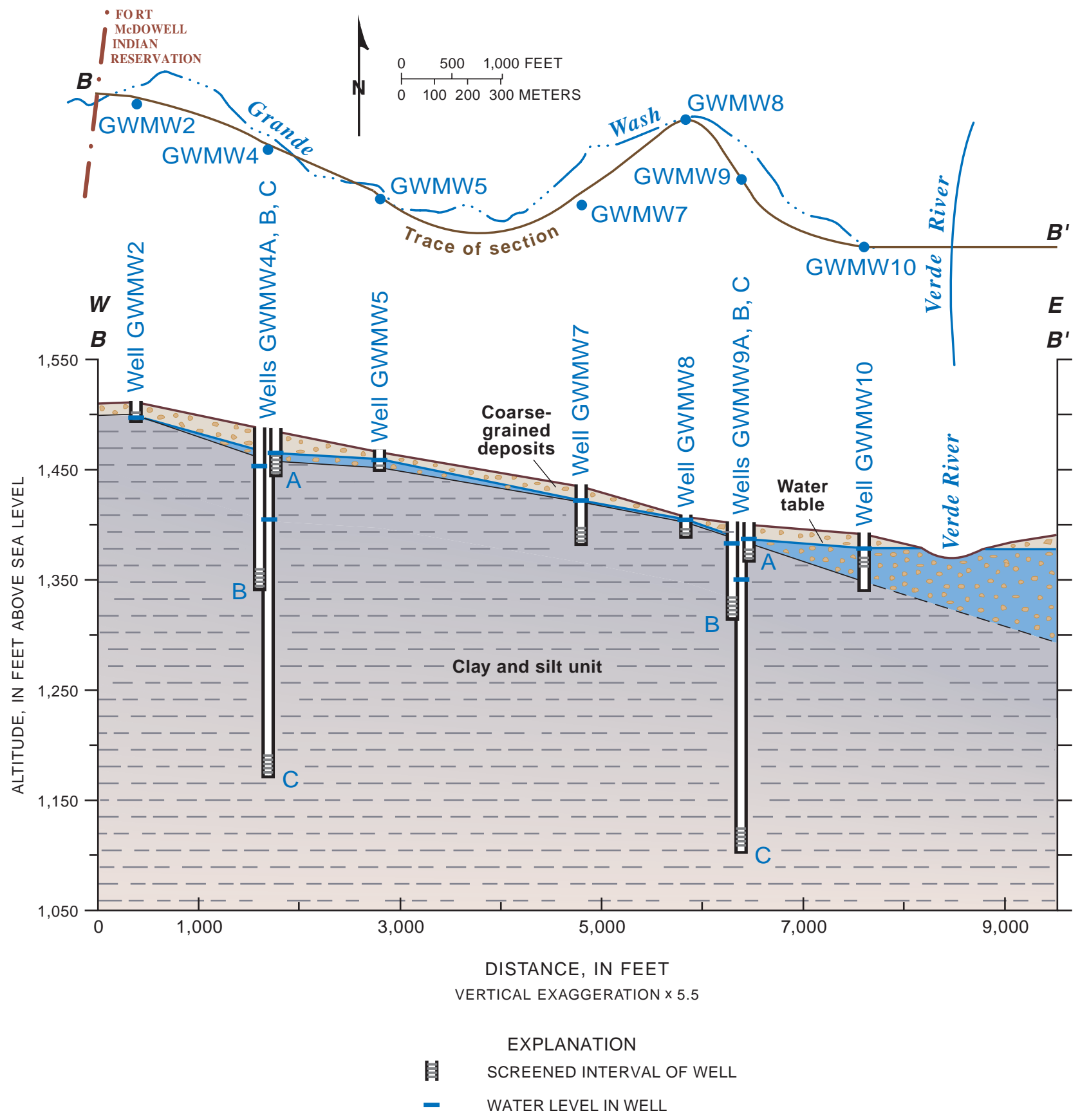

Figure 10. Altitude of the land surface and water table, water levels in nested monitor wells, and contact between coarse-grained deposits and the clay and silt unit, Grande Wash, Fort McDowell Indian Reservation, Arizona. 

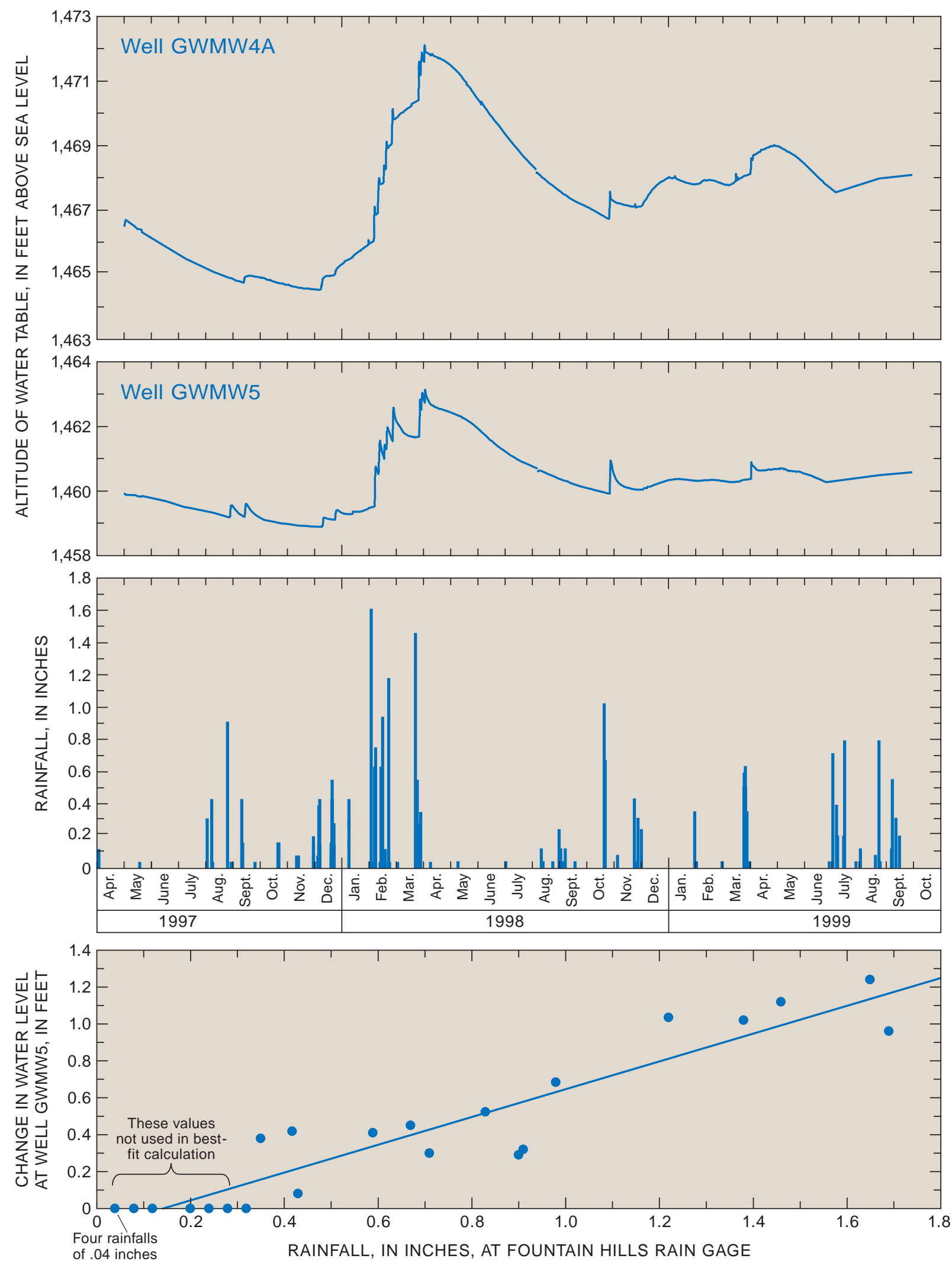

Figure 11. Water levels in selected wells, daily rainfall during period of study, and relation of rainfall and water-level change at well GWMW5, Grande Wash, Fort McDowell Indian Reservation, Arizona. 
After December, the water level varied in response to a combination of the stage of the Verde River and rainfall. Well GWMW10 is completed in coarsegrained deposits that are contiguous with the alluvial aquifer along the Verde River. Pumping at nearby wells probably also affected the water levels in well GWMW10 from May 1997 through March 1998 (fig. 12).

\section{Thickness and Hydraulic Conductivity of the Shallow Aquifer and Ground-Water Flux}

The subsurface lithology of Grande Wash was interpreted from EM and seismic-refraction data and well logs. EM soundings along the main channel of the wash were modeled and the results are shown in figure 13. The uppermost model layer has a conductivity of less than $16 \mathrm{mmhos} / \mathrm{m}$ and represents the coarse-grained deposits. Beneath this model layer is a layer that has a conductivity greater than $100 \mathrm{mmhos} / \mathrm{m}$ along most of the sounding line and represents the clay and silt unit. A third layer, having a conductivity of $10-50 \mathrm{mmhos} / \mathrm{m}$, was modeled; this layer probably represents the clay and silt unit with a greater fraction of sand. Maximum depth of investigation of the EM soundings is about $196.9 \mathrm{ft}$ (table 1), therefore, the elevation of the base of the third layer is not known. Results of additional EM soundings indicate that conductivity of the coarse-grained deposits adjacent to the main channel ranges from 10 to $37 \mathrm{mmhos} / \mathrm{m}$ whereas the conductivity of the clay and silt layer is greater than $70 \mathrm{mmhos} / \mathrm{m}$ (fig. 8 and table 2).

Thickness of the coarse-grained deposits adjacent to the main channel range from about 20 to $70 \mathrm{ft}$ (table 2). Modeled seismic refraction data indicated an uppermost model layer that transmits a pressure wave at a velocity of 1,100 to 3,600 ft/s (table 3). This layer ranges in thickness from about 12 to $50 \mathrm{ft}$ and probably represents the unsaturated part of the coarse-grained deposits in the study area. The lower model layer had pressure-wave velocities ranging from 4,600 to $7,000 \mathrm{ft} / \mathrm{s}$ and probably represents the saturated part of the coarse-grained deposits. Electromagnetic and seismic model results were consistent with log information from the monitor wells. Well-log information is summarized in table 4. Characteristics of the shallow alluvium such as hydraulic conductivity and hydraulic gradient affect the rate at which ground water moves toward the Verde River and to the nearby production wells. Although aquifer-test data are not available, hydraulic conductivity of the aquifer is estimated to be about $100 \mathrm{ft} / \mathrm{d}$, on the basis of geophysical data and well logs. This value is within the range of values derived from other studies of alluvial basins in southern Arizona (Anderson and others, 1992) - 30 to $90 \mathrm{ft} / \mathrm{d}$ for basin fill deposits and 200 to $400 \mathrm{ft} / \mathrm{d}$ for stream alluvium.

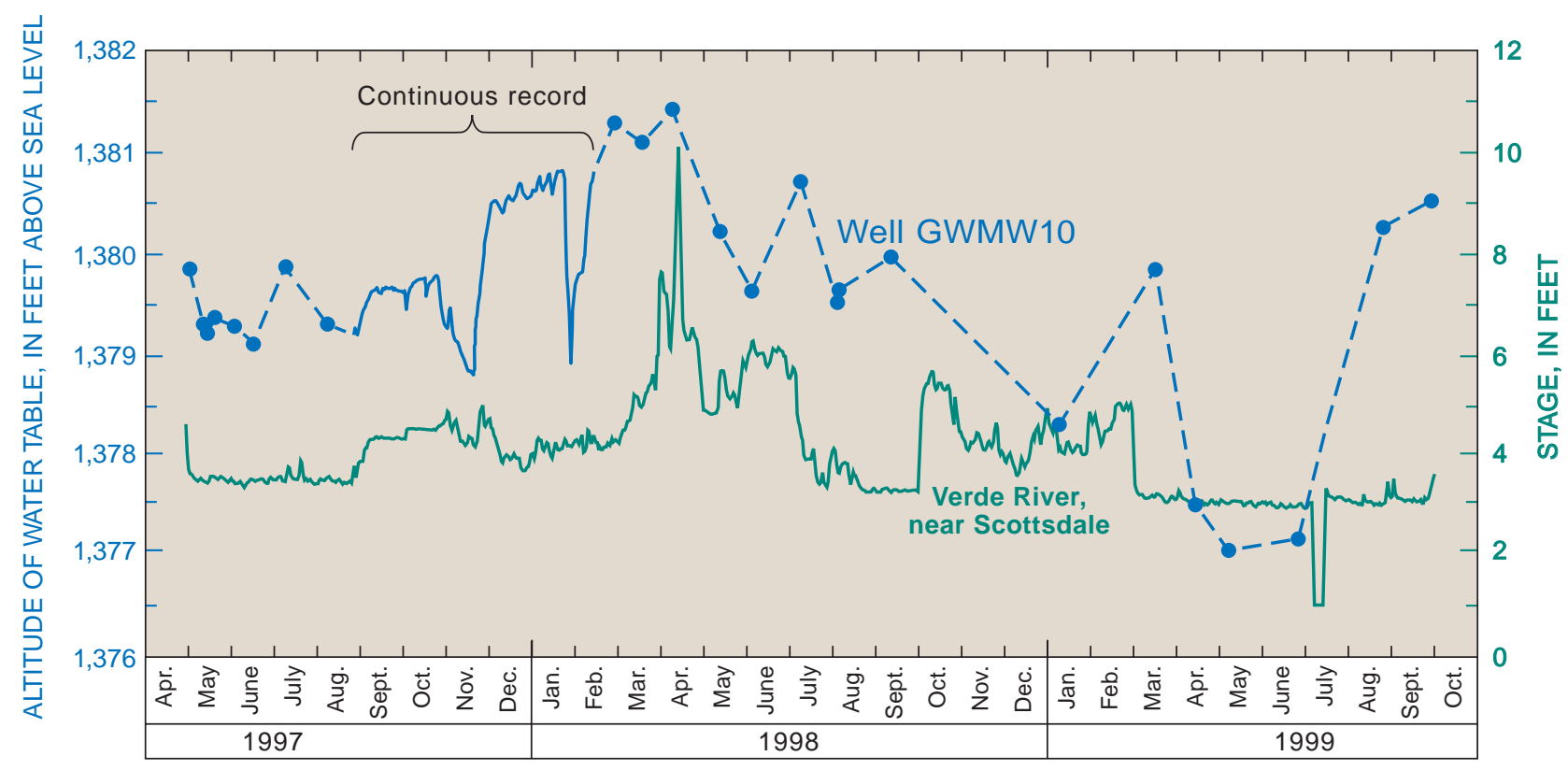

Figure 12. Water level in well GWMW10, Grande Wash, Fort McDowell Indian Reservation, Arizona, and stage of the Verde River near Scottsdale during period of study. 


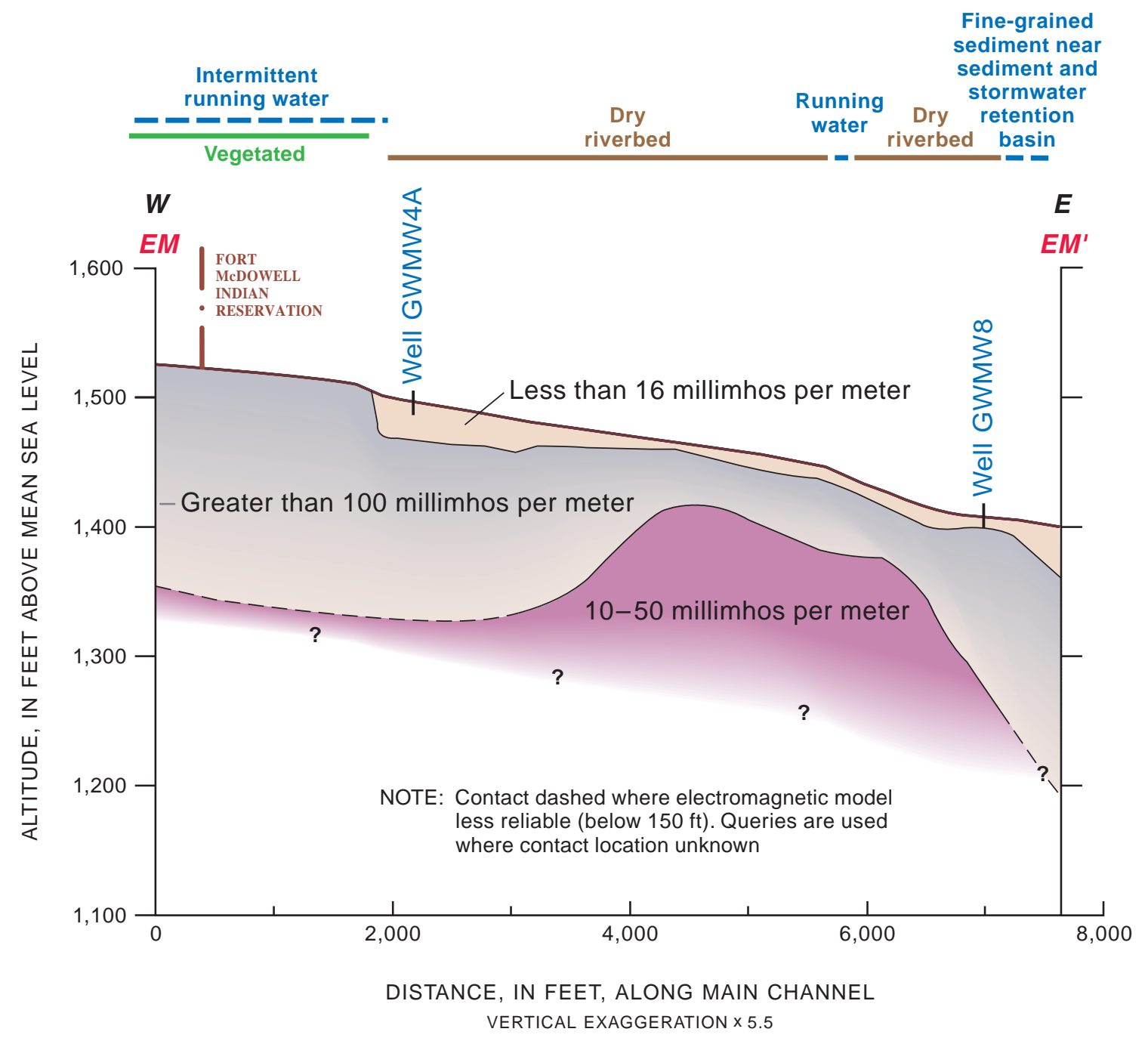

Figure 13. Electromagnetic model of Grande Wash along main-channel profile. See figure $\mathbf{5}$ for trace of electromagnetic profile.

Table 2. Model results of selected electromagnetic soundings adjacent to the main channel of Grande Wash, Fort McDowell Indian Reservation, Arizona

[>, greater than]

\begin{tabular}{cccc}
\hline $\begin{array}{c}\text { Electromagnetic sounding number } \\
\text { (see figure 5) }\end{array}$ & $\begin{array}{c}\text { Electrical conductivity of } \\
\text { model layer 1, } \\
\text { in millimhos per meter }\end{array}$ & $\begin{array}{c}\text { Model layer 1 thickness, } \\
\text { in feet }\end{array}$ & $\begin{array}{c}\text { Electrical conductivity of } \\
\text { model layer 2, } \\
\text { in millimhos per meter }\end{array}$ \\
\hline EM2 & 10 & 30 & $70-120$ \\
EM4 & 13 & 30 & 177 \\
EM6 & 34 & 20 & 200 \\
EM8 & 20 & 70 & $>200$ \\
EM9 & 37 & 28 & $>200$
\end{tabular}


Table 3. Model results of seismic-refraction data, Grande Wash, Fort McDowell Indian Reservation, Arizona

\begin{tabular}{clccc}
\hline $\begin{array}{c}\text { Seismic refraction line } \\
\text { (see figure 5) }\end{array}$ & Energy source & $\begin{array}{c}\text { Model layer 1 } \\
\text { average velocity, } \\
\text { in feet per second }\end{array}$ & $\begin{array}{c}\text { Model layer 1 thickness, } \\
\text { in feet }\end{array}$ & $\begin{array}{c}\text { Model layer 2 } \\
\text { average velocity, } \\
\text { in feet per second }\end{array}$ \\
\hline S1A & explosives & 3,600 & 20 & 5,800 \\
S1B & hammer & 1,900 & 15 & 4,600 \\
S1C & hammer & 2,500 & 15 & 4,800 \\
S2 & hammer & 1,100 & 15 & 5,300 \\
S3 & explosives & 2,100 & 30 & 5,900 \\
S4A & explosives & 3,700 & 10 & 5,600 \\
S4B & hammer & 1,700 & 15 & 4,900 \\
S5 & explosives & 2,700 & 50 & 5,700 \\
S6A & explosives & 3,000 & 30 & 6,300 \\
S6B & hammer & 1,500 & 12 & 4,900 \\
S7 & hammer & 2,400 & 15 & 4,700 \\
S8 & hammer & 2,700 & 50 & 7,000 \\
\hline
\end{tabular}

Table 4. Summary of information from monitor-well logs, Fort McDowell Indian Reservation, Arizona

[>, greater than; ND, water not detected in coarse-grained deposits]

\begin{tabular}{ccccc}
\hline $\begin{array}{c}\text { Well site } \\
\text { (see figure 5) }\end{array}$ & $\begin{array}{c}\text { Land surface elevation, } \\
\text { in feet }\end{array}$ & $\begin{array}{c}\text { Thickness of } \\
\text { coarse-grained deposits, } \\
\text { in feet }\end{array}$ & $\begin{array}{c}\text { Range in depth to water in } \\
\text { coarse-grained deposits, } \\
\text { in feet below land surface }\end{array}$ & $\begin{array}{c}\text { Range in saturated thickness } \\
\text { of coarse-grained deposits, } \\
\text { in feet }\end{array}$ \\
\hline GWMW1 & $1,522.84$ & 60 & ND & 0 \\
GWMW2 & $1,511.26$ & 12 & $10.2->12$ & $0-1.79$ \\
GWMW3 & $1,532.95$ & 20 & ND & 0 \\
GWMW4 & $1,486.43$ & 28 & $14.61-21.80$ & $6.20-13.39$ \\
GWMW5 & $1,465.74$ & 14 & $3.07-6.81$ & $7.19-10.93$ \\
GWMW6 & $1,449.01$ & 9 & $6.28->9$ & $0-2.72$ \\
GWMW7 & $1,434.50$ & 14 & $8.06-12.74$ & $1.26-5.94$ \\
GWMW8 & $1,407.08$ & 5 & $1.20-2.76$ & $2.24-3.80$ \\
GWMW9 & $1,400.42$ & 14.7 & $8.97-13.6$ & $1.10-5.73$ \\
GWMW10 & $1,392.39$ & 30 & $10.98-13.36$ & $16.64-19.02$ \\
\hline
\end{tabular}

The thickness and width of the saturated part of the aquifer were determined in order to compute the saturated cross-sectional area. The saturated thickness of the aquifer is the difference between the altitude of the base of the aquifer (top of the clay and silt unit) and the altitude of the water table. The altitude of the top of the underlying clay and silt unit was determined on the basis of well cuttings, borehole-geophysical logs, and surface geophysical data and is shown in figure 9. The altitude of the water table was determined periodically in all monitor wells that contain water. Three wells were instrumented to record water-levels hourly during parts of the study. The saturated thickness of the Grande Wash aquifer beneath the main channel varies with recharge but averages about $5 \mathrm{ft}$ and ranges from about 1 to $13 \mathrm{ft}$ (fig. 14). The saturated width of the aquifer also varies with recharge but is typically less than 2,000 ft and centered beneath the main channel. An average width of $1,333 \mathrm{ft}$ was used to calculate the cross-sectional area of the aquifer. 


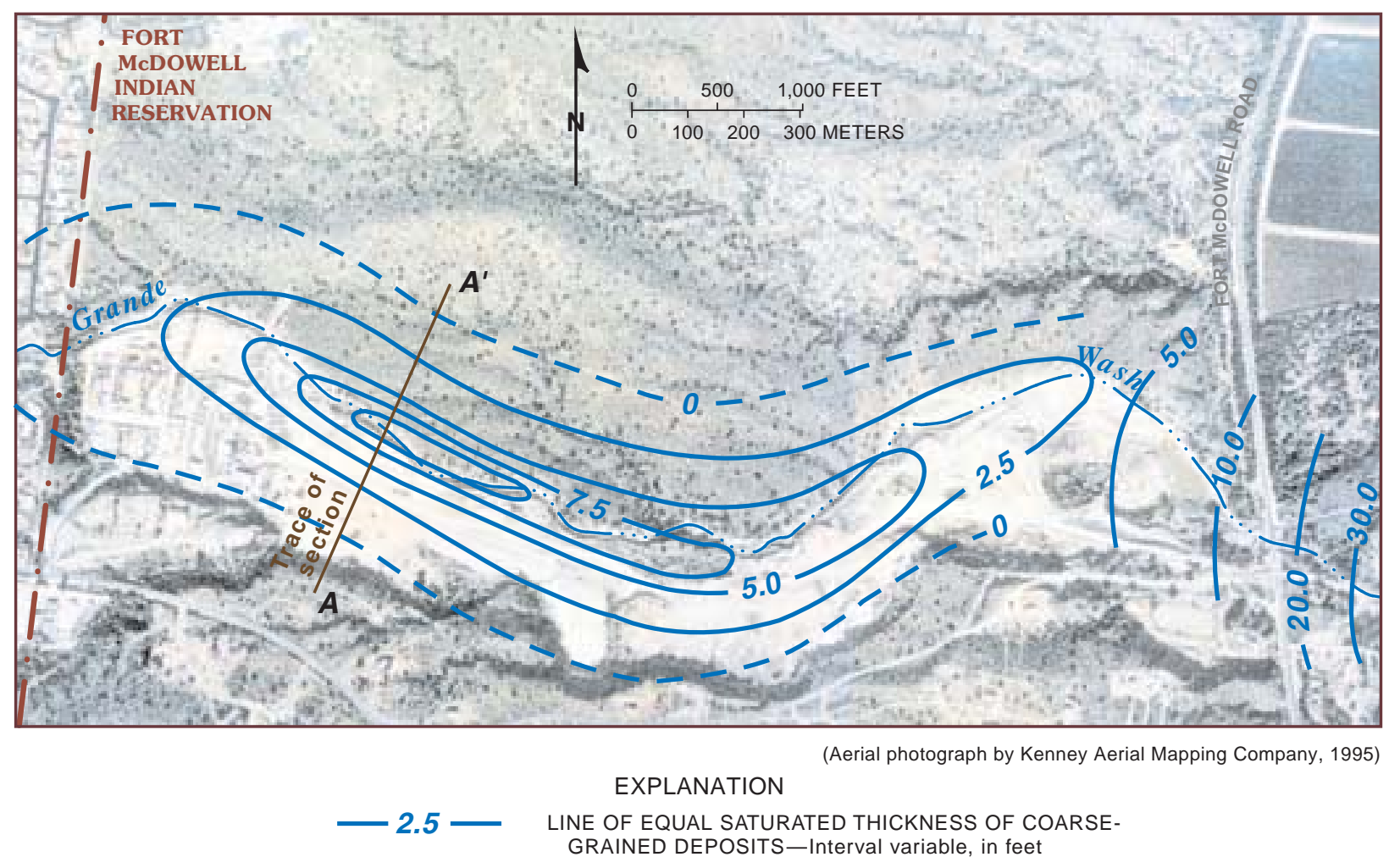

Figure 14. Estimated average saturated thickness of coarse-grained deposits, Grande Wash, Fort McDowell Indian Reservation, Arizona. See figure 8.

Because the saturated thickness tapers in both directions away from the main channel (fig. 14), an average saturated thickness of $3 \mathrm{ft}$ was used to calculate the cross-sectional area. The saturated cross-sectional area is estimated to be about $4,000 \mathrm{ft}^{2}$ (saturated thickness multiplied by saturated width). The flux of ground water through the Grande Wash aquifer toward the Verde River is estimated to be $8,000 \mathrm{ft}^{3} / \mathrm{d}\left(0.1 \mathrm{ft}^{3} / \mathrm{s}\right)$, using Darcy's Law:

$$
Q=K I A,
$$

where

$Q=$ flux of ground water, in cubic feet per day;

$K=$ hydraulic conductivity, in feet per day (100 $\mathrm{ft} / \mathrm{d}$ );

$I=\quad$ hydraulic gradient $(0.02 \mathrm{ft} / \mathrm{ft})$; and

$A=$ cross-sectional area of flow, in square feet $\left(4,000 \mathrm{ft}^{2}\right)$.
The estimated flux is based on average conditions in the aquifer. The flux, however, will vary in response to varying saturated thickness, width, and hydraulic gradient. Hydrographs for selected wells (fig. 11) indicate the saturated thickness of the coarse-grained deposits has varied by as much as $6 \mathrm{ft}$ at some wells during a 1-year period. Wells GWMW3 and GWMW6 were dry, or water levels were below the top of the clay and silt layer, for most of the period of record; however, water was detected in these wells after periods of high rainfall in the winter of 1997-98. As a result, the higher water level and increased aquifer width during the wettest periods resulted in an estimated cross-sectional area of about $20,000 \mathrm{ft}^{2}$. Use of this larger cross-sectional area increases the flux by a factor of about 5 to $40,000 \mathrm{ft}^{3} / \mathrm{d}\left(0.5 \mathrm{ft}^{3} / \mathrm{d}\right)$. Ground-water flow is eastward into the alluvial aquifer along the Verde River, and the ground water ultimately discharges into the Verde River. The average annual flow in the Verde River at the streamflow gaging station below Bartlett Dam (fig. 1) is $678 \mathrm{ft}^{3} / \mathrm{s}$ 
(Tadayon and others, 1998). Therefore, flux of ground water from the shallow aquifer beneath Grande Wash to the alluvial aquifer beneath the Verde River is minor compared to streamflow in the Verde.

Vertical-hydraulic gradients in the clay and silt unit are about $0.2 \mathrm{ft} / \mathrm{ft}$, which is an order of magnitude greater than horizontal-hydraulic gradients in the coarse-grained deposits. These gradients have been nearly constant during the period of study and have not varied in response to recharge. The estimated vertical flux through the clay and silt unit is about $7,000 \mathrm{ft}^{3} / \mathrm{d}$ on the basis of an assumed cross-sectional area of $12 \times 10^{6} \mathrm{ft}^{2}$ (area encircled by the zero contour line in figure 14) and a vertical-hydraulic conductivity of $0.003 \mathrm{ft} / \mathrm{d}$. The vertical-hydraulic conductivity of clay and silt is probably less than $0.003 \mathrm{ft} / \mathrm{d}$ on the basis of a hydraulic conductivity of $0.3 \mathrm{ft} / \mathrm{d}$ (Tom Anderson, Hydrologist, U.S. Geological Survey, written commun., 1980) and a 100:1 anisotropy, which is typical for fine grained units.

The volume of water in storage in the coarsegrained deposits was estimated on the basis of the geometry of the aquifer and an assumed porosity. Using a cross-sectional area of $4,000 \mathrm{ft}^{2}$, a length of $7,000 \mathrm{ft}$, and a porosity 0.2 , the volume of ground water held in storage in the coarse-grained deposits beneath Grande Wash is estimated to be about 5.6 million cubic $\mathrm{ft}$ (129 acre-ft).

\section{WATER CHEMISTRY AND QUALITY}

The chemistry and quality of surface water entering the reservation through Grande Wash, and of ground water in the shallow alluvial aquifer beneath Grande Wash is suitable for most purposes; however, surface-water and ground-water samples had high dissolved-solids, and dissolved-ion concentrations that exceeded SMCLs. Several VOC and pesticide compounds were detected in the surface water and ground water; however, concentrations of these compounds were less than the MCLs. The presence of VOC and pesticide compounds indicate that the quality of the water has been affected by anthropogenic activities.

\section{Surface Water}

Dissolved oxygen ranged from 10.8 to $13.5 \mathrm{mg} / \mathrm{L}$, which is typical for stormwater-runoff samples. Detergent suds were detected in the surface water at a severity of 2. Chemical oxygen demand ranged from 20 to 75 , which may indicate the presence of organic material. E. coli and fecal coliform, which are indicators of the presence of animal waste products, were detected at more than 2,000 colonies per 100 millimeters.

\section{Major lons and Nutrients}

Dissolved-ion concentrations in surface-water samples were varied but generally high (fig. 15). For example, chloride averaged $317 \mathrm{mg} / \mathrm{L}$ and ranged from 87 to $700 \mathrm{mg} / \mathrm{L}$; sulfate averaged $190 \mathrm{mg} / \mathrm{L}$ and ranged from 60 to $400 \mathrm{mg} / \mathrm{L}$. The SMCL for both chloride and sulfate is $250 \mathrm{mg} / \mathrm{L}$ (U.S. Environmental Protection Agency, 1996). The lowest concentrations were in a sample collected during the largest storm and closest in time to peak flow and could reflect a large component of stormwater in the sample relative to water from bank storage. Alternatively, this result could reflect a high degree of flushing of accumulated soil salts before sample collection. High concentrations of dissolved ions are indicative of redissolved salts that are mobilized by runoff in the drainage area. Samples that were collected several hours after peak flow and from flows that had occurred in response to relatively little rainfall contained high concentrations of dissolved ions (fig. 16). The higher concentration probably resulted from the larger component of water from bank storage in the sample and (or) from the smaller degree of flushing that had occurred before sample collection.

Nutrient concentrations in surface water were low. Nitrate ranged from 0.056 to $2.75 \mathrm{mg} / \mathrm{L}$ and phosphorus ranged from 0.019 to $0.227 \mathrm{mg} / \mathrm{L}$. 


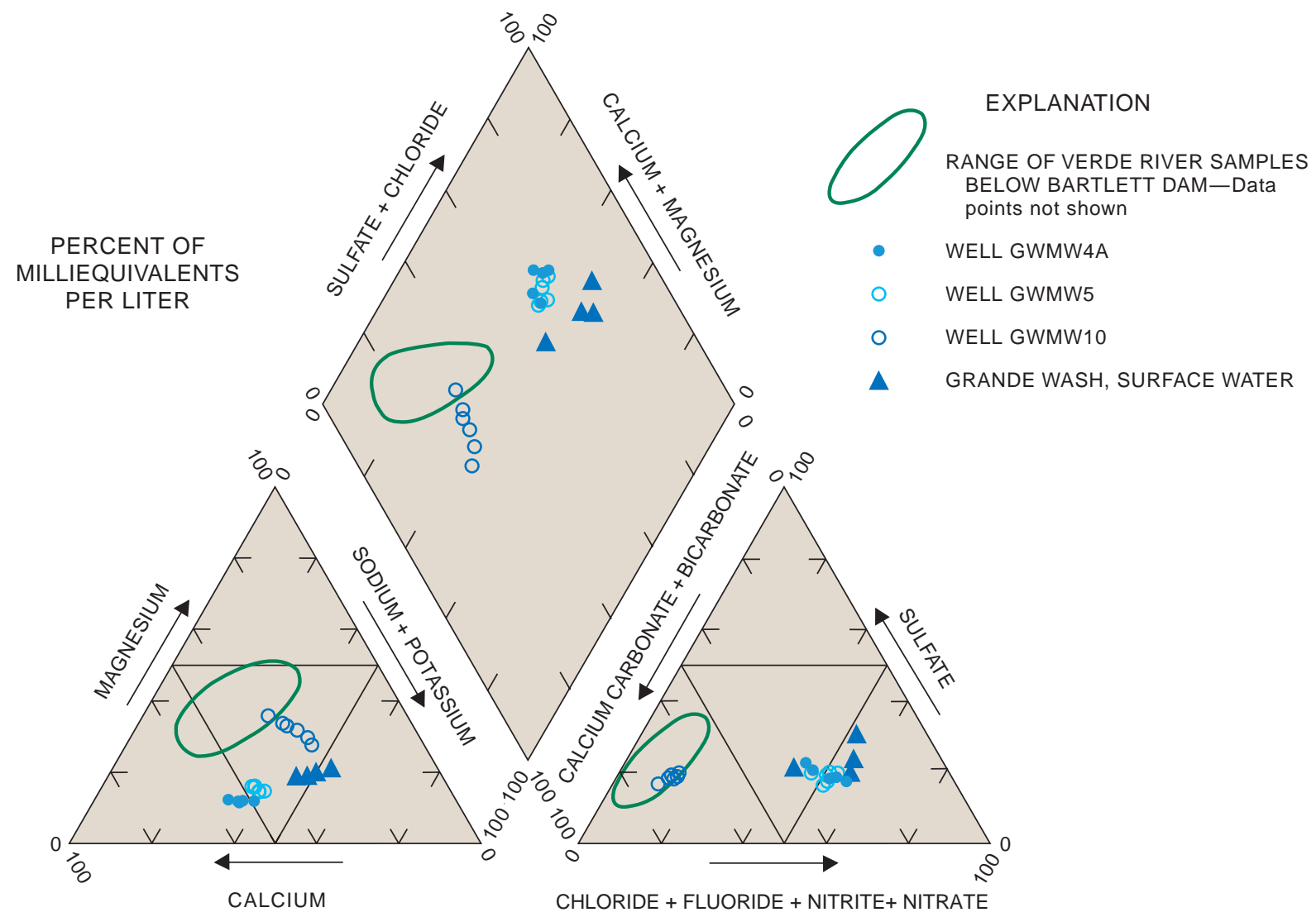

Figure 15. Relative proportions of major ions for surface-water and ground-water samples, Grande Wash, Fort McDowell Indian Reservation, Arizona.

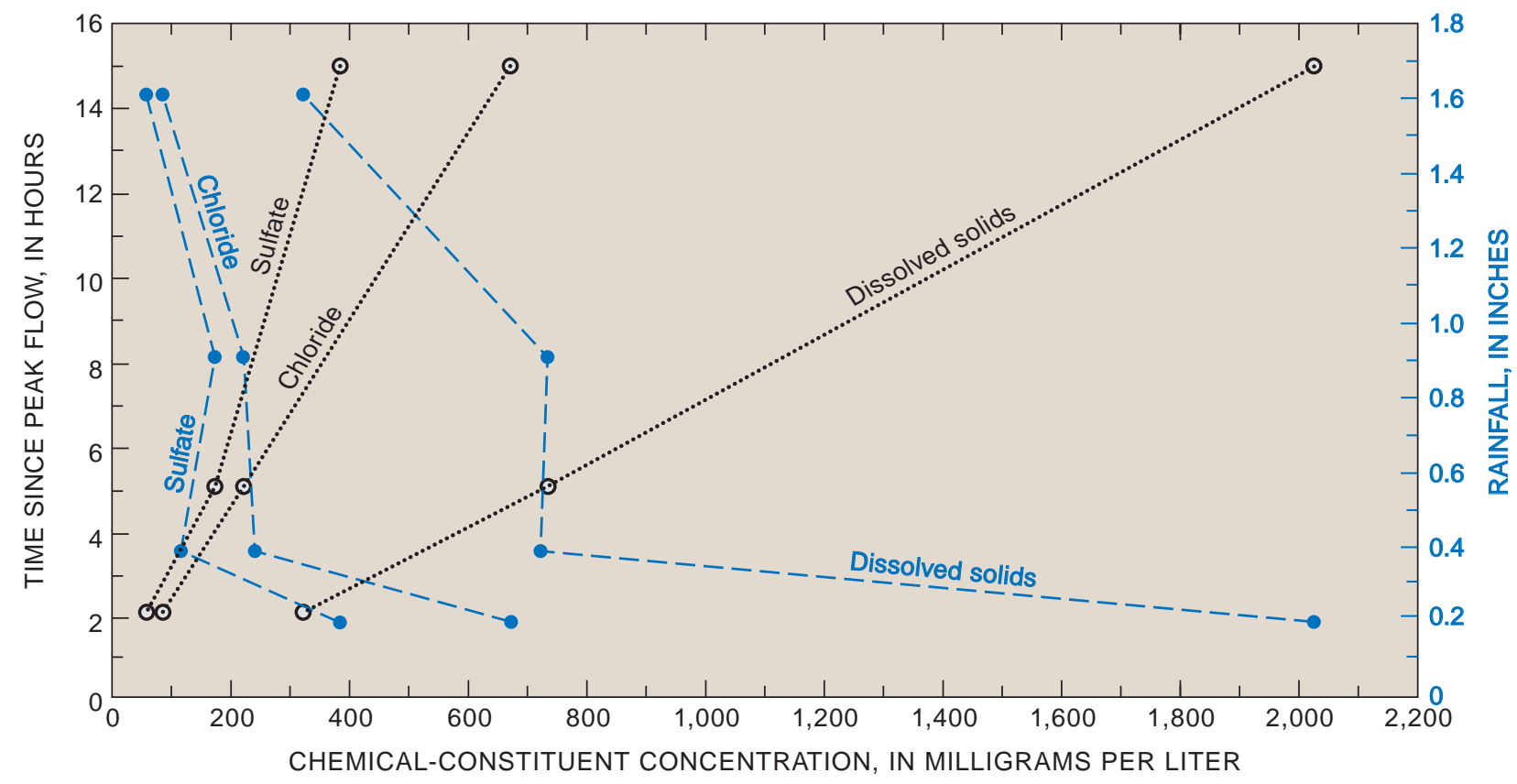

Figure 16. Concentration of selected constituents at surface-water sites in relation to time since peak flow and to rainfall, Grande Wash, Fort McDowell Indian Reservation, Arizona. 


\section{Organic Compounds}

Three VOCs were detected in surface-water samples. Chloroform $(0.023 \mu \mathrm{g} / \mathrm{L})$ is a chlorinated hydrocarbon, or trihalomethane, that can be formed by the reaction of chlorine with naturally occurring organic matter. The other two VOCs were 1,2,4trimethylbenzene $(0.024 \mu \mathrm{g} / \mathrm{L})$ and P-isopropyltoluene $(0.010 \mu \mathrm{g} / \mathrm{L})$. Each of these compounds reported concentrations below laboratory calibration standards; therefore, the concentrations are considered to be estimates. The concentrations of these compounds were well below the applicable USEPA MCL $-100 \mu \mathrm{g} / \mathrm{L}$ for total trihalomethanes, $5 \mu \mathrm{g} / \mathrm{L}$ for benzene compounds, and $100 \mu \mathrm{g} / \mathrm{L}$ for toluene compounds. Surface-water samples were analyzed for 88 pesticide compounds. Eight pesticide compoundsoryzalin $(0.960 \mu \mathrm{g} / \mathrm{L})$, simazine $(0.0224 \mu \mathrm{g} / \mathrm{L})$, atrazine $(0.004 \mu \mathrm{g} / \mathrm{L})$, diazinon $(0.161 \mu \mathrm{g} / \mathrm{L})$, chlorpyrifos $(0.0350 \mu \mathrm{g} / \mathrm{L})$, dacthal $(0.0080 \mu \mathrm{g} / \mathrm{L})$, prometon $(0.167 \mu \mathrm{g} / \mathrm{L})$, and pendmethalin $(0.0266 \mu \mathrm{g} / \mathrm{L})$ were reported at concentrations below USEPA MCLs and guidelines. Oryzalin, simazine and atrazine have USEPA MCLs of 200, 4 and $3 \mu \mathrm{g} / \mathrm{L}$, respectively; diazinon, chlorpyrifos, dacthal, and prometon have USEPA health advisory limits of 3, 20, 20, and $500 \mu \mathrm{g} / \mathrm{L}$, respectively; pendmethalin is a USEPA contaminant candidate.

\section{Trace Metals}

Concentrations of all trace metals except lead were below USEPA MCLs, SMCLs, and health advisory limits. The surface-water sample collected in January 1997 contained $80 \mu \mathrm{g} / \mathrm{L}$ of lead, which exceeds the USEPA action limit of $15 \mu \mathrm{g} / \mathrm{L}$ for required treatment techniques (U.S. Environmental Protection Agency, 1996). This lead detection is considered suspect because the total recovered lead concentration reported was less than $1 \mu \mathrm{g} / \mathrm{L}$. Additionally, the USGS National Water-Quality Laboratory reported problems with lead determinations at about the same time this sample was analyzed which resulted in a change in minimum reporting levels. Because no lead was detected in the samples collected in December 1997, February 1998, and July 1999, the January 1997 detection is judged to be an isolated occurrence. Arsenic concentrations (total and dissolved) in the surface-water samples ranged from $10-23 \mu \mathrm{g} / \mathrm{L}$ which was below the USEPA MCL of $50 \mu \mathrm{g} / \mathrm{L}$ at the time of sample collection and analyses.
In June 2000, however, the USEPA proposed a new MCL of $5 \mu \mathrm{g} / \mathrm{L}$ (U.S. Environmental Protection Agency, accessed June 27, 2000). The source of arsenic is probably from the dissolution of oxidized arsenic compounds that are typically found in basin-fill sediments (Robertson, 1991). The strontium concentration of $2,000 \mu \mathrm{g} / \mathrm{L}$ in one sample of surface water is near the USEPA health advisory limit of $2,500 \mu \mathrm{g} / \mathrm{L}$. Strontium commonly replaces calcium and potassium in granitic rocks. The source of strontium in the water sample is probably the granitic sands and gravels of the basin-fill sediments.

\section{Ground Water}

The concentrations of dissolved oxygen in the samples from wells GWMW4A, GWMW5, and GWMW10 (0.1 to $1.7 \mathrm{mg} / \mathrm{L}$ ) were much lower than those in samples of surface water from Grande Wash (10.8 to $13.5 \mathrm{mg} / \mathrm{L}$ ). This difference probably indicates that oxygen in the ground water is being consumed by buried organic material (probably landfill material) and (or) oxidizable minerals. Given the shallow depth to ground water and the rapid recharge to the aquifer, these oxygen-depleting processes occurred rapidly. Concentrations of dissolved oxygen are considerably higher in well GWMW10 (3.8 to $8.6 \mathrm{mg} / \mathrm{L}$ ), which indicates that less oxygen reduction is occurring at that site. No bacteria colonies (e. coli, fecal coliform, or fecal streptococci) were counted in the ground-water samples.

\section{Major lons and Nutrients}

The data from wells GWMW4A and GWMW5 indicate that major-ion chemistry of ground water is similar to that of surface water in Grande Wash, but is less variable (fig. 15). Concentrations of dissolved major ions in samples from these wells are considerably higher than typical concentrations in samples collected from well A-03-06 15ABA, which is completed in the regional aquifer (fig. 6). For example, chloride and sulfate concentrations from the Grande Wash wells averaged 398 and $207 \mathrm{mg} / \mathrm{L}$, respectively (table 5) whereas chloride and sulfate concentrations in water from the regional aquifer are typically about 50 and $30 \mathrm{mg} / \mathrm{L}$, respectively. Concentrations of dissolved major ions in samples from well GWMW10 were much lower than concentrations in samples from 
wells GWMW4A and GWMW5 and were similar to concentrations in samples from the Verde River. Well GWMW10 is about $870 \mathrm{ft}$ west of the Verde River. On the basis of major-ion chemistry, the river is the dominant source of recharge to ground water sampled at this well (fig. 15).

Concentrations of several constituents in samples from wells GWMW4A and GWMW5 were close to or higher than the USEPA MCLs or SMCLs.

Concentrations of dissolved chloride and sulfate varied from 280 to $470 \mathrm{mg} / \mathrm{L}$ and 170 to $240 \mathrm{mg} / \mathrm{L}$, respectively; dissolved-solids concentrations range from $1,120 \mathrm{mg} / \mathrm{L}$ to $1,490 \mathrm{mg} / \mathrm{L}$. These concentrations probably reflect dissolution of soil salts from the repeated evaporation of surface water and shallow ground water. Concentrations of these constituents at well GWMW10 were considerably lower than those at wells GWMW4A and GWMW5. Nitrate concentrations ranged from 2.39 to $8.29 \mathrm{mg} / \mathrm{L}$ at wells GWMW4A and GWMW5. Concentrations of nitrate generally decreased with time at both wells. The decreases may have been caused by microbial transformations, natural attenuation, dilution, dispersion, or a flushing of nitrate in the system. Concentrations of nitrate at well GWMW10 generally were higher than at wells GWMW4A and GWMW5, and ranged from 6.53 to $8.43 \mathrm{mg} / \mathrm{L}$. The source of nitrate at well GWMW10 is unknown; however, the well is within a few hundred feet of the community's alfalfa field; therefore, fertilizers are a potential source.
The mean, standard deviation, and range of constituent concentrations in ground water are listed in table 5, along with the associated USEPA MCL or SMCL, and possible sources of the constituents.

\section{Organic Compounds}

Ground-water samples were analyzed for more than 90 VOCs. Ten VOCs were detected, and concentrations of the compounds were low (table 6). Of the 10 VOCs detected only 2 were reported at concentrations above the minimum calibration standards: chloroform at 0.102 to $0.634 \mu \mathrm{g} / \mathrm{L}$; and dichlorobromomethane at $0.262 \mu \mathrm{g} / \mathrm{L}$. These compounds are chlorinated hydrocarbons that can be formed by the reaction of chlorine with naturally occurring organic matter. The other chlorinated hydrocarbons reported were at concentrations below calibration standards: methylchloride, methylenechloride, 1,4 dichlorobenzene, tetrachloroethylene and 1,1,1-trichloroethane at estimated concentrations of $0.009,0.114,0.037$ to $0.052,0.037$, and $0.016 \mu \mathrm{g} / \mathrm{L}$, respectively. The USEPA MCL for total trihalomethanes is $100 \mu \mathrm{g} / \mathrm{L}$.

Two chlorofluorocarbons (CFCs) were detected below calibration standards: dichlorodifluoromethane at estimated concentrations that ranged from 0.052 to $0.250 \mu \mathrm{g} / \mathrm{L}$, and trichlorofluormethane at 0.060 and $0.041 \mu \mathrm{g} / \mathrm{L}$. These gases are refrigerants and commonly are found in young, shallow ground water.

Table 5. Concentrations of selected constituents in ground water below Grande Wash, Fort McDowell Indian Reservation, Arizona

[Values are concentrations in milligrams per liter unless otherwise noted; MCL, Maximum Contaminant Level; SMCL, Secondary Maximum Contaminant Level; $\mathrm{n}$, number of samples; na, not applicable; $\mu \mathrm{g} / \mathrm{L}$, micrograms per liter; <, less than]

\begin{tabular}{|c|c|c|c|c|c|}
\hline \multirow[b]{2}{*}{ Constituent } & \multirow[b]{2}{*}{ Mean } & \multirow[b]{2}{*}{ Range } & \multicolumn{2}{|c|}{ U.S. Environmental Protection Agency } & \multirow[b]{2}{*}{ Possible sources } \\
\hline & & & $\mathbf{M C L}^{1}$ & SMCL $^{1}$ & \\
\hline Nitrate & $5.72(n=21)$ & $2.39-8.43$ & 10 & na & Fertilizers, waste water, natural \\
\hline Arsenic & $8.35 \mu \mathrm{g} / \mathrm{L}(\mathrm{n}=20)$ & 4-17 $\mu \mathrm{g} / \mathrm{L}$ & $50 \mu \mathrm{g} / \mathrm{L}$ & na & Sands and gravels (natural) \\
\hline Strontium & $1.2(n=20)$ & $0.93-1.6$ & ${ }^{2} 2.5$ & na & Sands and gravels (natural) \\
\hline Antimony & $2.0 \mu \mathrm{g} / \mathrm{L}(\mathrm{n}=7)$ & $<1.0-3.4 \mu \mathrm{g} / \mathrm{L}$ & $6.0 \mu \mathrm{g} / \mathrm{L}$ & na & Sands and gravels (natural) \\
\hline Chloride $^{3}$ & $393(n=14)$ & $280-470$ & na & 250 & $\begin{array}{l}\text { Fertilizers, waste water, evaporative } \\
\text { concentrates }\end{array}$ \\
\hline Sulfate $^{3}$ & $207(n=14)$ & $170-240$ & na & 250 & $\begin{array}{l}\text { Fertilizers, waste water, evaporative } \\
\text { concentrates }\end{array}$ \\
\hline Dissolved solids & $1,146(n=20)$ & $777-1,490$ & na & 500 & Evaporative concentrates \\
\hline
\end{tabular}

${ }^{1}$ U. S. Environmental Protection Agency (1996)

${ }^{2}$ Indicates U.S. Environmental Protection Agency Health Advisory

${ }^{3}$ Values are for wells GWMW4A and GWMW5 
Table 6. Volatile organic compounds (VOCs) detected in ground water, Grande Wash, Fort McDowell Indian Reservation, Arizona

$[\mathrm{ND}$, not detected]

\begin{tabular}{|c|c|c|c|c|}
\hline \multirow[b]{2}{*}{ Classification } & \multirow[b]{2}{*}{ Compound } & \multicolumn{2}{|c|}{ Concentrations, in micrograms per liter } & \multirow[b]{2}{*}{ Possible sources } \\
\hline & & Minimum & Maximum & \\
\hline \multirow[t]{7}{*}{ Chlorinated hydrocarbons } & Chloroform (trichloromethane) & 0.102 & 0.634 & Chlorinated water \\
\hline & Dichlorobromomethane & ${ }^{1} .028$ & 0.262 & Chlorinated water \\
\hline & Methylchloride & ND & ${ }^{1} .009$ & Chlorinated water \\
\hline & Methylenechloride & ND & ${ }^{1} 0.114$ & Chlorinated water \\
\hline & 1,4 dichlorobenzene & ${ }^{1} 0.037$ & ${ }^{1} 0.052$ & Chlorinated water \\
\hline & Tetrachloroethylene & ND & ${ }^{1} 0.037$ & $\begin{array}{l}\text { Chlorinated water, dry cleaning, } \\
\text { solvents }\end{array}$ \\
\hline & $1,1,1$ trichloroethane & ND & ${ }^{1} 0.016$ & $\begin{array}{l}\text { Adhesives, aerosols, textiles, } \\
\text { paints, inks, degreasers }\end{array}$ \\
\hline \multirow[t]{2}{*}{ Chlorofluorocarbons } & Trichlorofluoromethane & ${ }^{1} 0.041$ & ${ }^{1} 0.060$ & Chlorofluorocarbon refrigerant \\
\hline & Dichlorodifluoromethane & ${ }^{1} 0.052$ & ${ }^{1} 0.250$ & Chlorofluorocarbon refrigerant \\
\hline Hydrocarbon & 1,2,4-trimethylbenzene & ND & ${ }^{1} 0.011$ & Gas, pesticides, paint, plastics \\
\hline
\end{tabular}

The other VOC detected was 1,2,4-trimethylbenzene at $0.011 \mu \mathrm{g} / \mathrm{L}$; the concentration of this compound was below laboratory calibration standards. All VOC concentrations were below the USEPA MCLs. Groundwater samples were analyzed for 88 pesticide compounds. Two pesticide compounds-prometon and simazine-were detected in ground-water samples at concentrations that ranged from 0.051 to $0.0902 \mu \mathrm{g} / \mathrm{L}$ (table 7), which are below the USEPA MCLs.

\section{Trace Elements}

Arsenic, antimony, and strontium were reported at concentrations of about half of the USEPA MCLs (table 5). Concentrations of arsenic and antimony ranged from 4 to $17 \mu \mathrm{g} / \mathrm{L}$, and less than 1.0 to $3.4 \mu \mathrm{g} / \mathrm{L}$, respectively; samples with the highest concentrations were from well GWMW10. Only 1 of the 20 samples analyzed for arsenic had concentrations that are below the USEPA proposed MCL of $5 \mu \mathrm{g} / \mathrm{L}$ (U.S. Environmental Protection Agency, accessed June 27, 2000). Arsenic probably is from the dissolution of oxidized arsenic compounds in the basin-fill sediments (Robertson, 1991). Robertson (1991) states that the highest concentrations of arsenic in alluvial basins in Arizona were in well cuttings and outcrop samples from the Verde Formation in the Verde River Valley. Antimony is commonly found in rocks associated with copper and silver ores such as those in southern Arizona. Concentrations of strontium ranged from 929 to $1,600 \mu \mathrm{g} / \mathrm{L}$; the highest concentrations were in samples from well GWMW5. Strontium commonly replaces calcium and potassium in minerals associated with granitic rocks. Thus, the sources of strontium in surface waters and ground waters probably are the granitic sands and gravels of the basin fill sediment, stream-channel deposits, and surrounding granitic bedrock.

\section{STORMWATER-SEDIMENT CHEMISTRY}

Concentrations of trace metals in the stormwater sediment collected from the sediment retention basin at the downstream end of the wash (fig. 3) were low and several were below the laboratory's detection limit (see section entitled "Basic Data" at the back of the report). The concentrations of most organic compounds in the stormwater sediment were below detection limits. The only organic compounds present concentrations above detection limits were p-cresol at $1,000 \mu \mathrm{g} / \mathrm{kg}$ and two phthalate esters-bis (2-ethylhexyl) phthalate at $500 \mu \mathrm{g} / \mathrm{kg}$ and dibutyl phthalate at $55 \mu \mathrm{g} / \mathrm{kg}$. P-cresol is used in pesticides, disinfectants, and deodorizers, and phthalate esters are commonly used in plastics, hydraulic fluid, and electrical capacitors. 


\section{SUMMARY}

Concerns about surface and ground water in the Grande Wash area led the Fort McDowell Indian Community, in cooperation with the U.S. Geological Survey, to study the local hydrogeologic system. Grande Wash is an ephemeral tributary of the Verde River that traverses the west-central part of the Fort McDowell Indian Reservation. The wash originates on the east flank of the McDowell Mountains and drains eastward to the Verde River. This study determined (1) the quality of the surface water entering the reservation in Grande Wash, (2) the horizontal and vertical extent of the shallow alluvial aquifer beneath Grande Wash, (3) the directions of ground-water flow in the shallow aquifer, (4) the quantity and quality of ground water in the shallow aquifer, and (5) the chemistry of the stormwater sediment in Grande Wash.

The stream-channel deposits, landfill material, and the upper coarse-grained layer of the basin-fill sediments beneath Grande Wash are referred to as coarse-grained deposits and locally constitute the Grande Wash aquifer. Ground water in the shallow aquifer is mounded above a clay and silt unit, the base of which is below the bottom of the deepest monitor well (317 ft below land surface). The coarse-grained deposits overlying the clay and silt unit are as much as $60 \mathrm{ft}$ thick, but typically are less than $30 \mathrm{ft}$ within or immediately adjacent to the wash. Depth to water ranges from 1 to $22 \mathrm{ft}$ below land surface. The lateral extent of saturation is less than about $1,000 \mathrm{ft}$ from the main channel of Grande Wash, and varies in response to changes in amounts of recharge.

Water-level data indicate that the ground water in the coarse-grained deposits flows parallel to Grande Wash in response to a gradient of about $0.02 \mathrm{ft} / \mathrm{ft}$ toward the Verde River. The flux of ground water through the aquifer beneath Grande Wash toward the Verde River is about $8,000 \mathrm{ft}^{3} / \mathrm{d}$ on the basis of average conditions. The value for the saturated cross-sectional area during the wettest period of the study would have resulted in a five-fold increase in the flux estimate. Ground-water subflow from the shallow aquifer into the alluvial aquifer along the Verde River is minor compared to average flows in the Verde River. Nested wells at two sites indicate that a component of groundwater flow is downward into the clay and silt unit. The vertical hydraulic gradient in the clay and silt unit is $0.2 \mathrm{ft} / \mathrm{ft}$. Vertical flux through the clay and silt unit is estimated to be $7,000 \mathrm{ft}^{3} / \mathrm{d}$. The volume of ground water in storage in the Grande Wash aquifer under average conditions is about 5.6 million cubic $\mathrm{ft}$.

Surface-water samples collected in Grande Wash about 1,000 ft west of the reservation boundary were generally high in dissolved ions. Concentrations were related to the amount of rainfall and (or) to the time the sample was collected after peak streamflow occurred. The sample with the lowest dissolved-ion concentrations was collected during the period of greatest rainfall and closest in time to peak flow. The low concentrations probably reflect a large component of stormwater in the sample relative to water from bank storage, or a high degree of flushing of soil salts, or a combination of these factors. High concentrations are indicative of redissolved salts that can be expected to be mobilized by runoff in the drainage area. Concentrations of dissolved ions were high in samples that were collected several hours after peak flow and after relatively little rainfall. Flow in the wash during these conditions probably reflects a larger component of water from bank storage and (or) less flushing of the soil salts. Concentrations of nutrients were low in surface-water samples. No metals, other than lead, were reported at concentrations above USEPA MCLs and SMCLs. Lead, however, was not detected in follow-up samples; therefore, the initial detection was judged to be an isolated occurrence. The arsenic concentrations are higher than the proposed new MCL of $5 \mu \mathrm{g} / \mathrm{L}$. Three VOCs and eight pesticides were detected in the surface-water samples, and concentrations of these compounds were low.

The major-ion chemistry of ground water is similar to that of the surface water flowing in Grande Wash, but is less variable. The solutes in the ground water likely derive from dissolution of evaporatively concentrated soil salts. Water from the well closest to the Verde River had a lower concentration of solutes than the water from wells west of Fort McDowell Road, and had a major-ion chemistry similar to that of 
the Verde River. This similarity indicates that the river is the dominant source of recharge to ground water at this well.

Nitrate concentrations were relatively high in ground-water samples compared to concentrations in surface-water samples. Decreases in concentrations during the study suggests that dilution or microbial action may have occurred. Ten VOCs were detected in the samples from wells west of Fort McDowell Road. The concentrations of these compounds were near the detection limits. Two pesticides were detected in ground-water samples, and concentrations of these compounds were low. Arsenic, antimony, and strontium were reported at concentrations of about half of the USEPA MCLs. The concentrations of arsenic in 19 of the 20 ground-water samples is higher than the proposed MCL of $5 \mu \mathrm{g} / \mathrm{L}$. These trace elements probably derive from natural sources. Samples from wells near landfills contained low concentrations of dissolved oxygen probably because of buried organic material or oxidizable minerals.

Concentrations of metals in the stormwater sediment collected from the sediment retention basin at the downstream end of the wash were low and several were below the laboratory detection limit. The concentrations of most organic compounds in the stormwater sediment were below detection limits. The only organic compounds present at concentrations above the detection limit were p-cresol at $1,000 \mu \mathrm{g} / \mathrm{kg}$ and two phthalate esters-bis (2-ethylhexyl) phthalate at $500 \mu \mathrm{g} / \mathrm{kg}$ and dibutyl phthalate at $55 \mu \mathrm{g} / \mathrm{kg}$. $\mathrm{P}$-cresol is used in pesticides, disinfectants, and deodorizers, and phthalate esters are commonly used in plastics, hydraulic fluid, and electric capacitors.

\section{REFERENCES CITED}

Anderson, T.W., Freethey, G.W., and Tucci, Patrick, 1992, Geohydrology and water resources of alluvial basins in south-central Arizona and parts of adjacent states: U.S. Geological Survey Professional Paper 1406-B, 67 p.

Fenneman, N.M., 1931, Physiography of the western United States: New York, McGraw-Hill, 534 p.
Hammet, B.A., and Herther, R.L., 1995, Maps showing groundwater conditions in the Phoenix Active Management Area, Maricopa, Pinal, and Yavapai counties, Arizona-1992: State of Arizona, Department of Water Resources, Hydrologic-Map Series Report No. 27, 3 sheets.

Horowitz, A.J., and Elrick, K.A., 1987, The relation of stream sediment surface area, grain size, and composition to trace metal chemistry: Applied Geochemistry, v. 2, p. 437-451.

Interpex Limited, 1994, EMIX 34 PLUS, Electromagnetic conductivity data processing software, Golden, Colorado, Interpex Limited, v.p.

Kenney Aerial Mapping Company, October 1995: Phoenix, Arizona, Kenney Aerial Mapping Company.

McDonald, H.R., and Padgett, H.D. Jr., 1945, Geology and ground-water resources of the Verde River Valley near Fort McDowell, Arizona: U.S. Geological Survey unpublished report, $98 \mathrm{p}$.

McNeill, J.D., 1980, Electromagnetic terrain conductivity measurements at low induction numbers: Mississauga, Ontario, Canada, Geonics Ltd. Technical Note TN-6, $15 \mathrm{p}$.

Reeter, R.W., and Remick, W.H., 1986, Maps showing groundwater conditions in the West Salt River, East Salt River, Lake Pleasant, Carefree and Fountain Hills subbasins of the Phoenix active management area, Maricopa, Pinal and Yavapai counties, Arizona-1983: State of Arizona, Department of Water Resources Hydrologic Map Series Report No. 12, 3 sheets.

Rimrock Geophysics Inc., 1995, Seismic refraction Interpretation Programs, Rimrock Geophysics Inc., Lakewood, Colorado.

Robertson, F.N., 1991, Geochemistry of ground water in alluvial basins of Arizona and adjacent parts of Nevada, New Mexico, and California: U.S. Geological Survey Professional Paper 1406-C, 90 p.

Ross, P.P., 1977, Map showing ground-water conditions in the lower Verde River area, Maricopa, Yavapai, and Gila counties, Arizona-1976: U.S. Geological Survey Water-Resources Investigations Report 77-113, 1 sheet.

SCS Engineers, 1996a, Preliminary landfill investigation report, Grande Wash Landfill, Fort McDowell Indian Reservation: Phoenix, Arizona, SCS Engineers, report, v.p.

SCS Engineers, 1996b, Phase I focused environmental site assessment, Grande Wash, Fort McDowell MohaveApache Indian Community: Phoenix, Arizona, SCS Engineers, report, v.p. 
Schumann, H.H., 1967, Water resources of Lower Sycamore Creek, Maricopa County, Arizona: Unpublished Master's thesis, University of Arizona, $54 \mathrm{p}$.

Shelton, L.R., and Capel. P.D., 1994, Guidelines for collecting and processing samples of stream bed sediment for analysis of trace elements and organic contaminants for the National Water-Quality Assessment Program: U.S. Geological Survey OpenFile Report 94-458, 20 p.

Tadayon, Saied, Duet, N.R., Fisk, G.G., McCormack, H.F., Pope, G.L., and Rigas, P.D., 1998, Water Resources Data, Arizona, water year 1997: U.S. Geological Survey Water-Data Report AZ-97-1, 416 p.

Thomsen, B.W., and Dennis, P.E., 1963, Water salvage possibilities on Sycamore Creek watershed, Maricopa County, Arizona: Arizona State Land Dept., Proceedings of the 7th Annual Watershed Symposium, p. $16-18$.
Thomsen, B.W., and Schumann, H.H., 1968, Water resources of the Sycamore Creek watershed, Maricopa County, Arizona: U.S. Geological Survey Water-Supply Paper 1861, 53 p.

U.S. Environmental Protection Agency, 1996, Drinking Water Regulations and Health Advisories: U.S. Environmental Protection Agency Report EPA 822-B96-002, October 1996, $10 \mathrm{p}$.

U.S. Environmental Protection Agency, 2000, Office of Ground Water and Drinking Water, Proposed Revision to Arsenic Drinking Water Standard, accessed June 27, 2000, at URL http:// www.epa.gov/safewater/ars/ proposalfs.html.

Wilson, E.D., Moore, R.T., and Pierce, H.W., 1957, Geologic map of Maricopa County, Arizona: Arizona Bureau of Mines, scale 1:375,000. 
Table 7. Water-chemistry and stormwater-sediment chemistry data, Grande Wash, Fort McDowell Indian Reservation, Arizona

[GWMW, Grande Wash monitoring well; DEG C, degree Celsius; MM, millimeter; G/M, gallons per minute; US/CM, microsiemens per centimeter; MG/L, milligrams per liter; UG/L, micrograms per liter; UG/KG, micrograms per kilogram; G/KG, grams per kilogram. Dashes indicate no data]

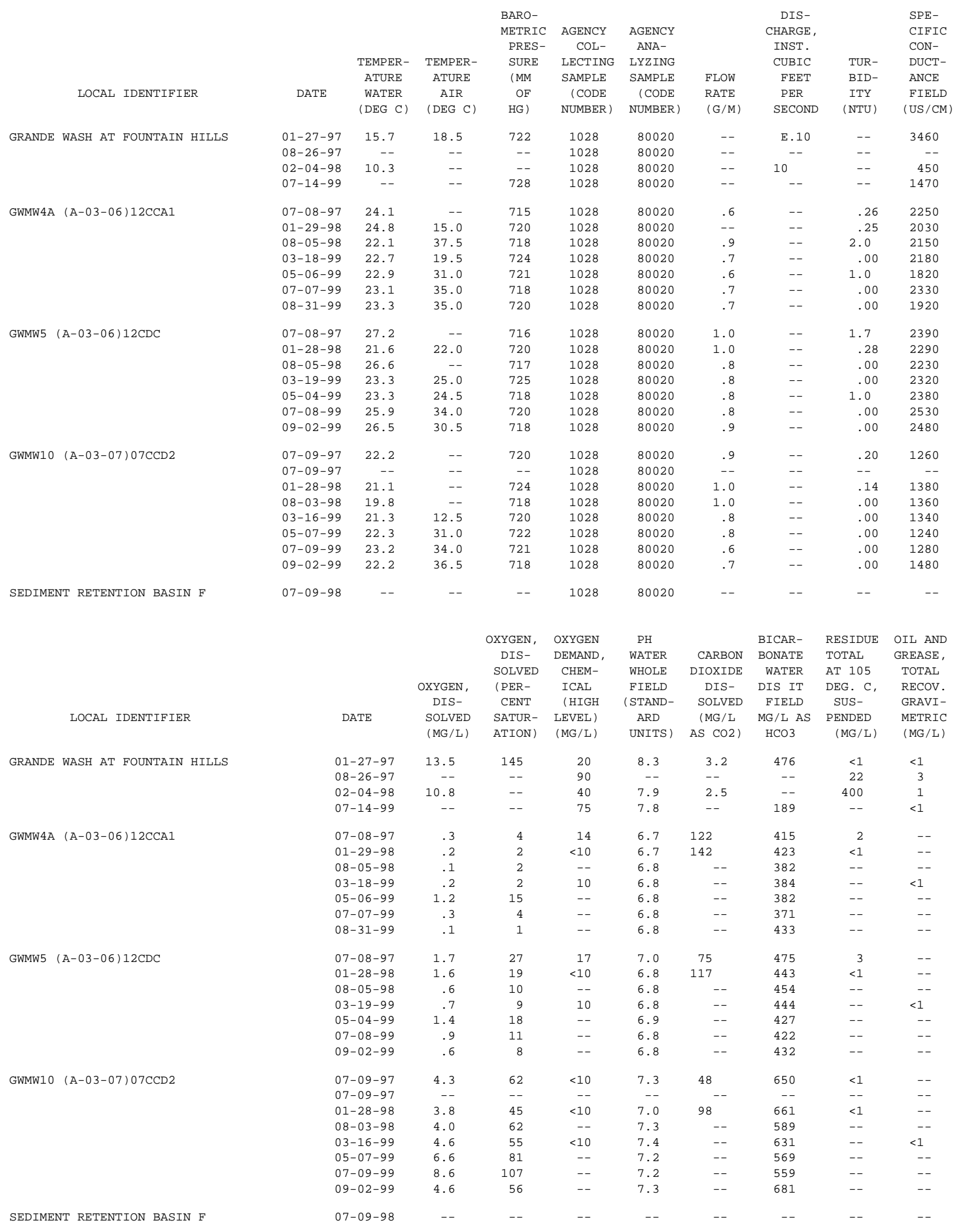


Table 7. Water-chemistry and stormwater-sediment chemistry data, Grande Wash, Fort McDowell Indian Reservation, ArizonaContinued

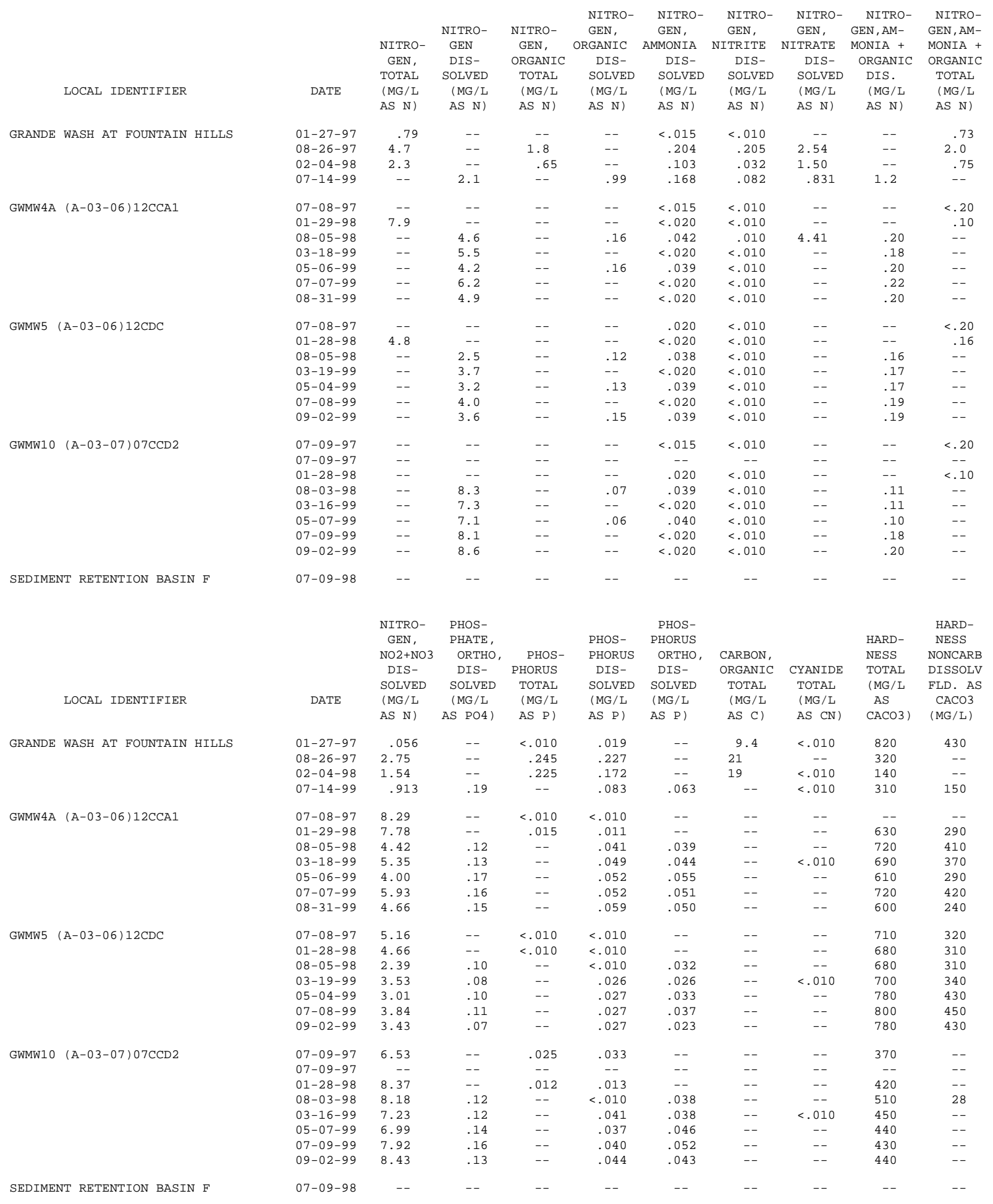


Table 7. Water-chemistry and stormwater-sediment chemistry data, Grande Wash, Fort McDowell Indian Reservation, ArizonaContinued

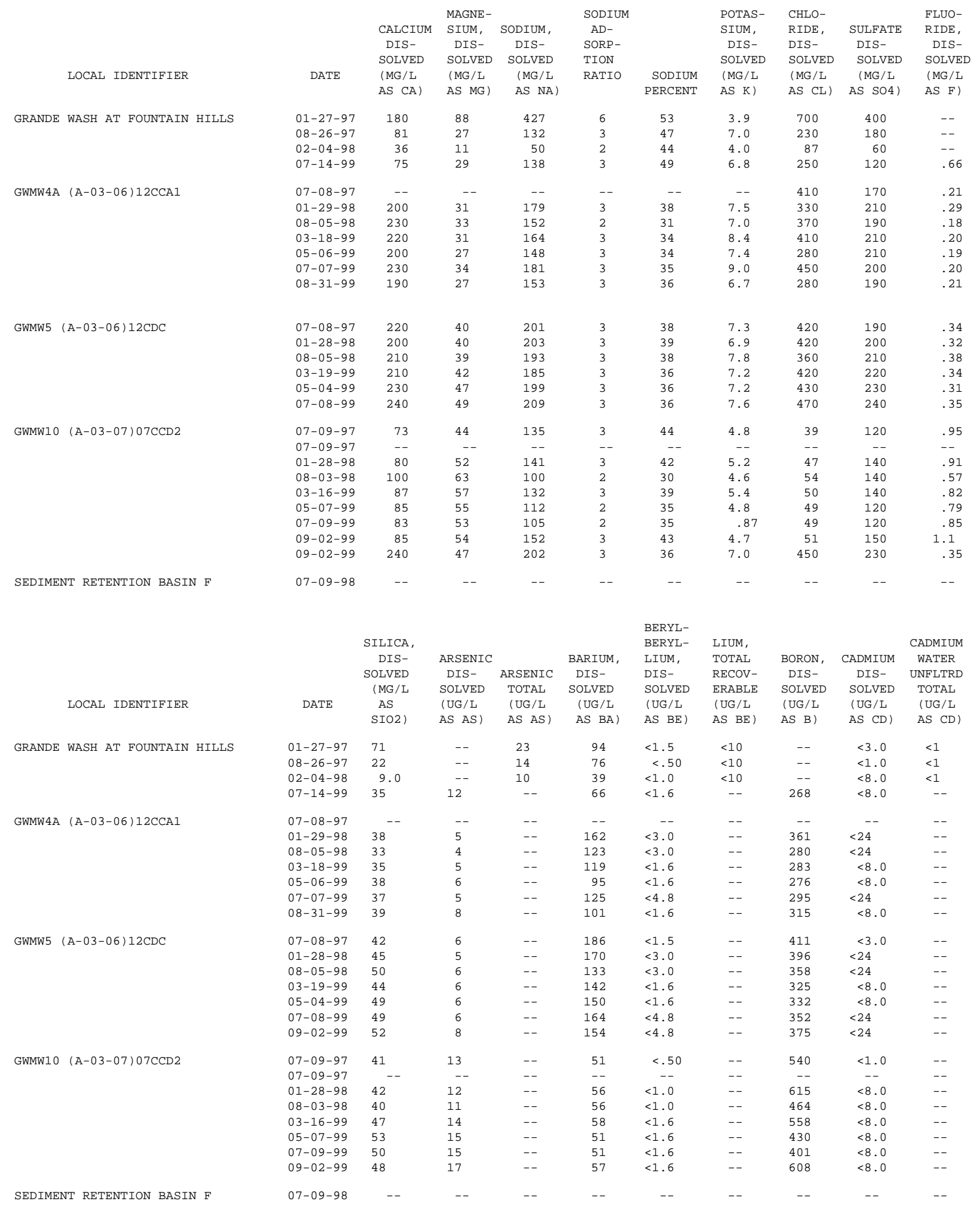


Table 7. Water-chemistry and stormwater-sediment chemistry data, Grande Wash, Fort McDowell Indian Reservation, ArizonaContinued

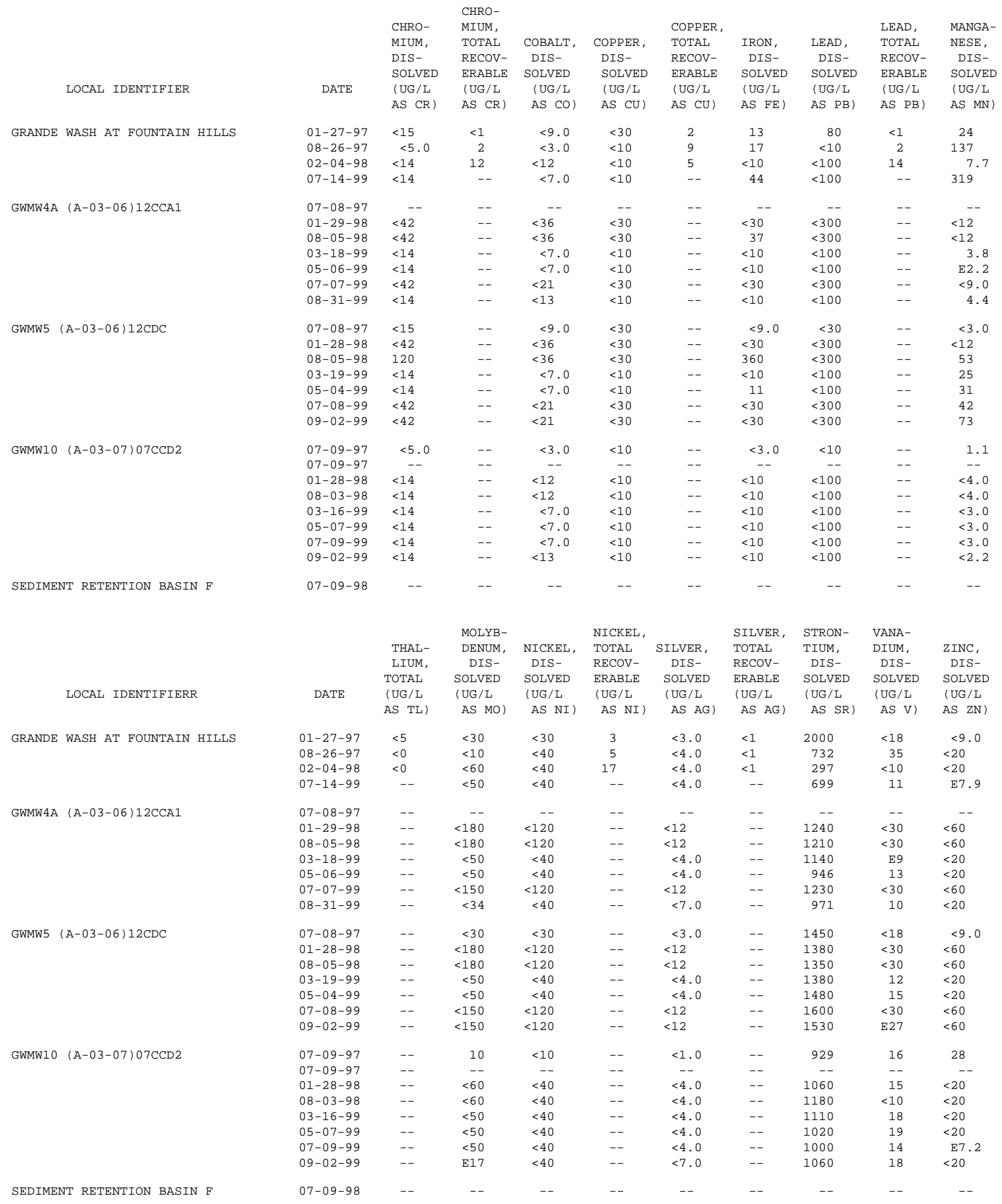


Table 7. Water-chemistry and stormwater-sediment chemistry data, Grande Wash, Fort McDowell Indian Reservation, ArizonaContinued

\begin{tabular}{|c|c|c|c|c|c|c|c|c|c|c|c|}
\hline & LOCAL IDENTIFIER & DATE & $\begin{array}{l}\text { ZINC, } \\
\text { TOTAL } \\
\text { RECOV- } \\
\text { ERABLE } \\
\text { (UG/L } \\
\text { AS ZN) }\end{array}$ & $\begin{array}{l}\text { ANTI- } \\
\text { MONY, } \\
\text { DIS- } \\
\text { SOLVED } \\
\text { (UG/L } \\
\text { AS SB) }\end{array}$ & $\begin{array}{l}\text { ALUM- } \\
\text { INUM, } \\
\text { DIS- } \\
\text { SOLVED } \\
\text { (UG/L } \\
\text { AS AL) }\end{array}$ & $\begin{array}{l}\text { LITHIUM } \\
\text { DIS- } \\
\text { SOLVED } \\
\text { (UG/L } \\
\text { AS LI) }\end{array}$ & $\begin{array}{l}\text { SELE- } \\
\text { NIUM, } \\
\text { DIS- } \\
\text { SOLVED } \\
\text { (UG/L } \\
\text { AS SE) }\end{array}$ & $\begin{array}{l}\text { SELE- } \\
\text { NIUM, } \\
\text { TOTAL } \\
\text { (UG/L } \\
\text { AS SE) }\end{array}$ & $\begin{array}{c}\text { DETER- } \\
\text { GENT } \\
\text { SUDS } \\
\text { (SEVER- } \\
\text { ITY) }\end{array}$ & $\begin{array}{l}\text { PROP- } \\
\text { CHLOR, } \\
\text { WATER, } \\
\text { DISS, } \\
\text { REC } \\
\text { (UG/L) }\end{array}$ & $\begin{array}{l}\text { BUTYL- } \\
\text { ATE, } \\
\text { WATER, } \\
\text { DISS, } \\
\text { REC } \\
\text { (UG/L) }\end{array}$ \\
\hline \multirow[t]{4}{*}{ GRANDE } & WASH AT FOUNTAIN HILLS & $01-27-97$ & $<10$ & -- & -- & 120 & -- & $<1$ & -- & -- & -- \\
\hline & & $08-26-97$ & 10 & -- & -- & 40 & -- & 8 & -- & -- & -- \\
\hline & & $02-04-98$ & 70 & -- & -- & 14 & -- & $<1$ & -- & -- & -- \\
\hline & & $07-14-99$ & -- & $<1.0$ & $<10$ & 42 & $<1$ & -- & 2 & $<.0070$ & $<.0020$ \\
\hline \multirow[t]{7}{*}{ GWMW4A } & $(\mathrm{A}-03-06) 12 \mathrm{CCA} 1$ & $07-08-97$ & -- & -- & -- & -- & -- & -- & -- & -- & -- \\
\hline & & $01-29-98$ & -- & 1.1 & $<30$ & 43 & 3 & -- & -- & -- & -- \\
\hline & & $08-05-98$ & -- & $<1.0$ & $<30$ & 39 & 1 & -- & -- & $<.0070$ & $<.0020$ \\
\hline & & $03-18-99$ & -- & $<1.0$ & $<10$ & 33 & 2 & -- & -- & $<.0070$ & $<.0020$ \\
\hline & & $05-06-99$ & -- & $<1.0$ & $<10$ & 33 & 2 & -- & -- & -- & -- \\
\hline & & $07-07-99$ & -- & $<1.0$ & $<30$ & 32 & $<1$ & -- & -- & -- & -- \\
\hline & & $08-31-99$ & -- & $<1.0$ & $<15$ & 33 & 2 & -- & -- & -- & -- \\
\hline \multirow[t]{7}{*}{ GWMW5 } & $(A-03-06) 12 C D C$ & $07-08-97$ & -- & 2.1 & 5.9 & 40 & 1 & -- & -- & -- & -- \\
\hline & & $01-28-98$ & -- & 1.1 & $<30$ & 40 & 2 & -- & -- & -- & -- \\
\hline & & $08-05-98$ & -- & 1.0 & $<30$ & 41 & $<1$ & -- & -- & -- & -- \\
\hline & & $03-19-99$ & -- & $<1.0$ & $<10$ & 35 & 2 & -- & -- & $<.0070$ & $<.0020$ \\
\hline & & $05-04-99$ & -- & $<1.0$ & $<10$ & 40 & 1 & -- & -- & -- & -- \\
\hline & & $07-08-99$ & -- & $<1.0$ & $<30$ & 36 & 2 & -- & -- & -- & -- \\
\hline & & $09-02-99$ & -- & $<1.0$ & $<30$ & 41 & 2 & -- & -- & -- & -- \\
\hline \multirow[t]{8}{*}{ GWMW10 } & $(\mathrm{A}-03-07) 07 \mathrm{CCD} 2$ & $07-09-97$ & -- & 3.4 & 12 & 63 & $<1$ & -- & -- & -- & -- \\
\hline & & $07-09-97$ & -- & -- & -_ & -- & -_ & -- & -- & -- & -- \\
\hline & & $01-28-98$ & -- & 3.1 & $<10$ & 70 & 1 & -- & -- & -- & -- \\
\hline & & $08-03-98$ & -- & 2.0 & $<10$ & 63 & $<1$ & -- & -- & -- & -- \\
\hline & & $03-16-99$ & -- & $<1.0$ & $<10$ & 75 & 2 & -- & -- & $<.0070$ & $<.0020$ \\
\hline & & $05-07-99$ & -- & $<1.0$ & $<10$ & 78 & 3 & -- & -- & -- & -- \\
\hline & & $07-09-99$ & -- & $<1.0$ & $<10$ & 74 & $<1$ & -- & -- & -- & -- \\
\hline & & $09-02-99$ & -- & $<1.0$ & $<15$ & 72 & 1 & -- & -- & -- & -- \\
\hline \multirow{2}{*}{\multicolumn{2}{|c|}{ SEDIMENT RETENTION BASIN F }} & $07-09-98$ & -- & -- & -- & -- & -- & -- & -- & -- & -- \\
\hline & & DATE & $\begin{array}{l}\text { BRO- } \\
\text { MACIL, } \\
\text { WATER, } \\
\text { DISS, } \\
\text { REC } \\
\text { (UG/L) }\end{array}$ & $\begin{array}{l}\text { SI- } \\
\text { MAZINE, } \\
\text { WATER, } \\
\text { DISS, } \\
\text { REC } \\
\text { (UG/L) }\end{array}$ & $\begin{array}{l}\text { PRO- } \\
\text { METON, } \\
\text { WATER, } \\
\text { DISS, } \\
\text { REC } \\
\text { (UG/L) }\end{array}$ & $\begin{array}{l}\text { DEETHYL } \\
\text { ATRA- } \\
\text { ZINE, } \\
\text { WATER, } \\
\text { DISS, } \\
\text { REC } \\
\text { (UG/L) }\end{array}$ & $\begin{array}{l}\text { CYANA- } \\
\text { ZINE, } \\
\text { WATER, } \\
\text { DISS, } \\
\text { REC } \\
\text { (UG/L) }\end{array}$ & $\begin{array}{c}\text { FONOFOS } \\
\text { WATER } \\
\text { DISS } \\
\text { REC } \\
\text { (UG/L) }\end{array}$ & $\begin{array}{l}\text { TRITIUM } \\
\text { TOTAL } \\
\text { (PCI/L) }\end{array}$ & $\begin{array}{c}\text { DI- } \\
\text { BROMO- } \\
\text { METHANE } \\
\text { WATER } \\
\text { WHOLE } \\
\text { RECOVER } \\
\text { (UG/L) }\end{array}$ & $\begin{array}{l}\text { COLI- } \\
\text { FORM, } \\
\text { FECAL, } \\
0.7 \\
\text { UM-MF } \\
\text { (COLS./ } \\
100 \mathrm{ML})\end{array}$ \\
\hline \multirow[t]{4}{*}{ GRANDE } & WASH AT FOUNTAIN HILLS & $01-27-97$ & -- & -- & -- & -- & -- & -- & -- & $<.800$ & -- \\
\hline & & $08-26-97$ & -- & -- & -- & -- & -- & -- & -- & -- & -- \\
\hline & & $02-04-98$ & -- & -- & -- & -- & -- & -- & -- & $<.100$ & - \\
\hline & & $07-14-99$ & $<.0350$ & .0224 & .167 & $<.0020$ & $<.0040$ & $<.0030$ & -- & -- & $>2000$ \\
\hline \multirow[t]{7}{*}{ GWMA4A } & $(\mathrm{A}-03-06) 12 \mathrm{CCA} 1$ & $07-08-97$ & -- & -- & -- & -- & -- & -- & -- & $<.200$ & -- \\
\hline & & $01-29-98$ & -- & -- & -- & -- & -- & -- & -- & $<.050$ & -- \\
\hline & & $08-05-98$ & $<.470$ & .0902 & .0296 & $<.0020$ & $<.0040$ & $<.0030$ & 13 & $<.050$ & $<1$ \\
\hline & & $03-18-99$ & $<.350$ & .0813 & .0250 & $<.0020$ & $<.0040$ & $<.0030$ & -- & $<.050$ & $<1$ \\
\hline & & $05-06-99$ & -- & -- & -- & -- & -- & -- & -- & -- & -- \\
\hline & & $07-07-99$ & -- & -- & -- & -- & -- & -- & -- & -- & -- \\
\hline & & $08-31-99$ & -- & -- & -- & -- & -- & -- & -- & -- & -- \\
\hline \multirow[t]{7}{*}{ GWMW5 ( } & $(\mathrm{A}-03-06) 12 \mathrm{CDC}$ & $07-08-97$ & -- & -- & -- & -- & -- & -- & -- & $<.200$ & -- \\
\hline & & $01-28-98$ & -- & -- & -- & -- & -- & -- & -- & -- & -- \\
\hline & & $08-05-98$ & -- & -- & -- & -- & -- & -- & 15 & -- & -- \\
\hline & & $03-19-99$ & $<.240$ & .0580 & E. 0151 & $<.0020$ & $<.0040$ & $<.0030$ & -- & $<.050$ & $<1$ \\
\hline & & $05-04-99$ & -- & -- & - & - & -- & -- & -- & -- & -- \\
\hline & & $07-08-99$ & -- & -- & -- & -- & -- & -- & -- & -- & -- \\
\hline & & $09-02-99$ & -- & -- & -- & -- & -- & -- & -- & -- & -- \\
\hline \multirow[t]{8}{*}{ GWMA10 } & $(\mathrm{A}-03-07) 07 \mathrm{CCD} 2$ & $07-09-97$ & -- & -- & -- & -- & -- & -- & -- & $<.200$ & -- \\
\hline & & $07-09-97$ & -- & -- & -- & -- & -- & -- & -- & $<.200$ & -- \\
\hline & & $01-28-98$ & -- & -- & -- & -- & -- & -- & -- & -- & -- \\
\hline & & $08-03-98$ & -- & -- & -- & -- & -- & -- & 8.0 & -- & -- \\
\hline & & $03-16-99$ & $<.0350$ & .0161 & $<.0180$ & $<.0020$ & $<.0040$ & $<.0030$ & -- & $<.050$ & $<1$ \\
\hline & & $05-07-99$ & -- & -- & -- & -- & -- & -- & -- & -- & -- \\
\hline & & $07-09-99$ & -- & -- & -- & -- & -- & -- & -- & -- & -- \\
\hline & & $09-02-99$ & -- & -- & -- & -- & -- & -- & -- & -- & -- \\
\hline SEDIMEN & NT RETENTION BASIN F & $07-09-98$ & -- & -- & -- & -- & -- & -- & -- & -- & -- \\
\hline
\end{tabular}


Table 7. Water-chemistry and stormwater-sediment chemistry data, Grande Wash, Fort McDowell Indian Reservation, ArizonaContinued

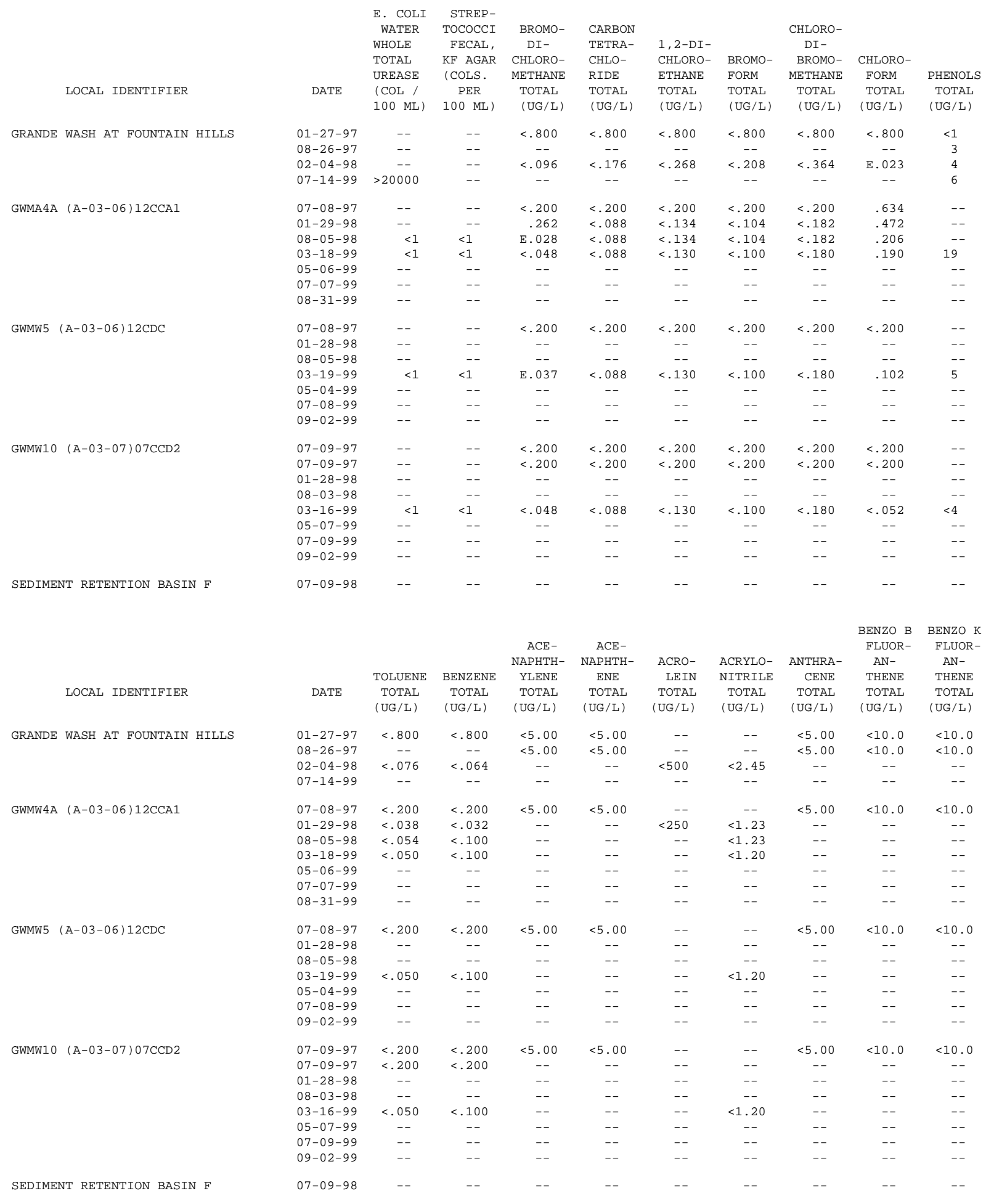


Table 7. Water-chemistry and stormwater-sediment chemistry data, Grande Wash, Fort McDowell Indian Reservation, ArizonaContinued

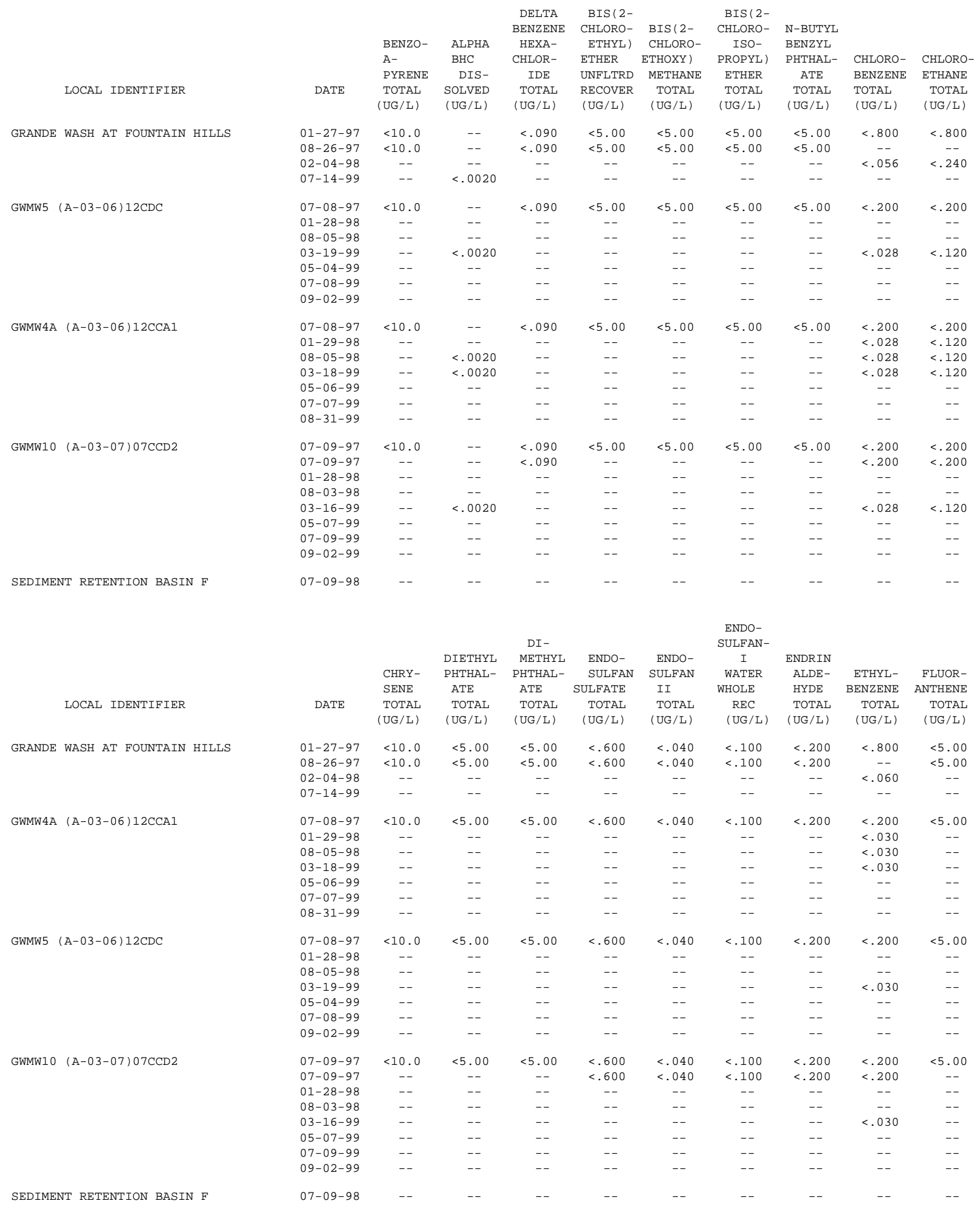


Table 7. Water-chemistry and stormwater-sediment chemistry data, Grande Wash, Fort McDowell Indian Reservation, ArizonaContinued

\begin{tabular}{|c|c|c|c|c|c|c|c|c|c|c|c|}
\hline \multirow{2}{*}{\multicolumn{2}{|c|}{ LOCAL IDENTIFIER }} & & ENE & UNFLTRD & UNFLTRD & PYRENE & PHORONE & BROMIDE & RIDE & RIDE & AMINE \\
\hline & & DATE & $\begin{array}{l}\text { TOTAL } \\
\text { (UG/L) }\end{array}$ & $\begin{array}{c}\text { RECOVER } \\
(\mathrm{UG} / \mathrm{L})\end{array}$ & $\begin{array}{l}\text { RECOVER } \\
(\mathrm{UG} / \mathrm{L})\end{array}$ & $\begin{array}{l}\text { TOTAL } \\
\text { (UG/L) }\end{array}$ & $\begin{array}{l}\text { TOTAL } \\
\text { (UG/L) }\end{array}$ & $\begin{array}{l}\text { TOTAL } \\
\text { (UG/L) }\end{array}$ & $\begin{array}{l}\text { TOTAL } \\
\text { (UG/L) }\end{array}$ & $\begin{array}{l}\text { TOTAL } \\
\quad(\mathrm{UG} / \mathrm{L})\end{array}$ & $\begin{array}{l}\text { TOTAL } \\
\text { (UG/L) }\end{array}$ \\
\hline \multirow[t]{4}{*}{ GRANDE } & WASH AT FOUNTAIN HILLS & $01-27-97$ & $<5.00$ & $<5.00$ & $<5.00$ & $<10.0$ & $<5.00$ & $<.800$ & $<.800$ & $<.800$ & $<5.00$ \\
\hline & & $08-26-97$ & $<5.00$ & $<20.0$ & $<5.00$ & $<10.0$ & $<5.00$ & -- & -- & -- & $<5.00$ \\
\hline & & $02-04-98$ & -- & -- & $<.724$ & -- & -- & $<.296$ & $<.508$ & $<.764$ & -- \\
\hline & & $07-14-99$ & -- & -- & -- & -- & -- & -- & -- & -- & -- \\
\hline \multirow[t]{7}{*}{ GWMW4A } & $(\mathrm{A}-03-06) 12 \mathrm{CCA} 1$ & $07-08-97$ & $<5.00$ & $<20.0$ & $<5.00$ & $<10.0$ & $<5.00$ & $<.200$ & $<.200$ & $<.200$ & $<5.00$ \\
\hline & & $01-29-98$ & -- & -- & $<.362$ & -- & -- & $<.148$ & $<.254$ & $<.382$ & -- \\
\hline & & $08-05-98$ & -- & -- & $<.362$ & -- & -- & $<.148$ & E.009 & $<.382$ & -- \\
\hline & & $03-18-99$ & -- & -- & $<.360$ & -- & -- & $<.150$ & $<.250$ & $<.380$ & -- \\
\hline & & $05-06-99$ & -- & -- & -- & -- & -- & -- & -- & -- & -- \\
\hline & & $07-07-99$ & -- & -- & -- & -- & -- & -- & -- & -- & -- \\
\hline & & $08-31-99$ & -- & -- & -- & -- & -- & -- & -- & -- & -- \\
\hline \multirow[t]{7}{*}{ GWMW5 } & $(A-03-06) 12 C D C$ & $07-08-97$ & $<5.00$ & $<20.0$ & $<5.00$ & $<10.0$ & $<5.00$ & $<.200$ & $<.200$ & $<.200$ & $<5.00$ \\
\hline & & $01-28-98$ & -- & -- & -- & -- & -- & -- & -- & -- & -- \\
\hline & & $08-05-98$ & -- & -- & -- & -- & -- & -- & -- & -- & -- \\
\hline & & $03-19-99$ & -- & -- & $<.360$ & -- & -- & $<.150$ & $<.250$ & $<.380$ & -- \\
\hline & & $05-04-99$ & -- & -- & -- & -- & -- & -- & -- & -- & -- \\
\hline & & $07-08-99$ & -- & -- & -- & -- & -- & -- & -- & -- & -- \\
\hline & & $09-02-99$ & -- & -- & -- & -- & -- & -- & -- & -- & -- \\
\hline \multirow[t]{8}{*}{ GWMW10 } & $(\mathrm{A}-03-07) 07 \mathrm{CCD} 2$ & $07-09-97$ & $<5.00$ & $<20.0$ & $<5.00$ & $<10.0$ & $<5.00$ & $<.200$ & $<.200$ & $<.200$ & $<5.00$ \\
\hline & & $07-09-97$ & -- & -- & -- & -- & -- & $<.200$ & $<.200$ & E.114 & -- \\
\hline & & $01-28-98$ & -- & -- & -- & -- & -- & -- & -- & -- & -- \\
\hline & & $08-03-98$ & -- & -- & -- & -- & -- & -- & -- & -- & -- \\
\hline & & $03-16-99$ & -- & -- & $<.360$ & -- & -- & $<.150$ & $<.250$ & $<.380$ & -- \\
\hline & & $05-07-99$ & -- & -- & -- & -- & -- & -- & -- & -- & -- \\
\hline & & $07-09-99$ & -- & -- & -- & -- & -- & -- & -- & -- & -- \\
\hline & & $09-02-99$ & -- & -- & -- & -- & -- & -- & -- & -- & -- \\
\hline \multirow{5}{*}{\multicolumn{2}{|c|}{ SEDIMENT RETENTION BASIN F }} & $07-09-98$ & -- & -- & -- & -- & -- & -- & -- & -- & -- \\
\hline & & & $\mathrm{N}-\mathrm{NITRO}$ & $\mathrm{N}-\mathrm{NITRO}$ & BENZENE & PARA- & & & TETRA- & TRI- & \\
\hline & & & -SODI- & -SODI- & NITRO- & CHLORO- & & & CHLORO- & CHLORO- & $1,1-\mathrm{DI}-$ \\
\hline & & & PHENYL- & METHYL- & WATER & $\begin{array}{l}\text { META } \\
\text { CRFSOT }\end{array}$ & PHENAN- & & ETHYL- & FLUORO- & CHLORO- \\
\hline & & & AMINE & AMINE & UNFLTRD & CRESOL & & PYRENE & ENE & METHANE & ETHANE \\
\hline & LOCAL IDENTIFIER & DATE & $\begin{array}{l}\text { TOTAL } \\
\text { (UG/L) }\end{array}$ & $\begin{array}{l}\text { TOTAL } \\
\text { (UG/L) }\end{array}$ & $\begin{array}{l}\text { RECOVER } \\
(\mathrm{UG} / \mathrm{L})\end{array}$ & $\begin{array}{l}\text { TOTAL } \\
\text { (UG/L) }\end{array}$ & $\begin{array}{l}\text { TOTAL } \\
\text { (UG/L) }\end{array}$ & $\begin{array}{l}\text { TOTAL } \\
\text { (UG/L) }\end{array}$ & $\begin{array}{l}\text { TOTAL } \\
\text { (UG/L) }\end{array}$ & $\begin{array}{l}\text { TOTAL } \\
\text { (UG/L) }\end{array}$ & $\begin{array}{l}\text { TOTAL } \\
\text { (UG/L) }\end{array}$ \\
\hline \multirow[t]{4}{*}{ GRANDE } & WASH AT FOUNTAIN HILLS & $01-27-97$ & $<5.00$ & $<5.00$ & $<5.00$ & $<30.0$ & $<5.00$ & $<5.00$ & $<.800$ & $<.800$ & $<.800$ \\
\hline & & $08-26-97$ & $<5.00$ & $<5.00$ & $<5.00$ & $<30.0$ & $<5.00$ & $<5.00$ & -- & -- & -- \\
\hline & & $02-04-98$ & -- & -- & -- & -- & -- & -- & $<.076$ & $<.184$ & $<.132$ \\
\hline & & $07-14-99$ & -- & -- & -- & -- & -- & -- & -- & -- & -- \\
\hline \multirow[t]{7}{*}{ GWMW4A } & $(\mathrm{A}-03-06) 12 \mathrm{CCA} 1$ & $07-08-97$ & $<5.00$ & $<5.00$ & $<5.00$ & $<30.0$ & $<5.00$ & $<5.00$ & $<.200$ & $<.200$ & $<.200$ \\
\hline & & $01-29-98$ & -- & -- & -- & -- & -- & -- & E.037 & E.060 & $<.066$ \\
\hline & & $08-05-98$ & -- & -- & -- & -- & -- & -- & $<.102$ & $<.092$ & $<.066$ \\
\hline & & $03-18-99$ & -- & -- & -- & -- & -- & -- & $<.100$ & E.041 & $<.066$ \\
\hline & & $05-06-99$ & -- & -- & -- & -- & -- & -- & -- & -- & -- \\
\hline & & $07-07-99$ & -- & -- & -- & -- & -- & -- & -- & -- & -- \\
\hline & & $08-31-99$ & -- & -- & -- & -- & -- & -- & -- & -- & -- \\
\hline \multirow[t]{7}{*}{ GWMW5 } & $(\mathrm{A}-03-06) 12 \mathrm{CDC}$ & $07-08-97$ & $<5.00$ & $<5.00$ & $<5.00$ & $<30.0$ & $<5.00$ & $<5.00$ & $<.200$ & $<.200$ & $<.200$ \\
\hline & & $01-28-98$ & -- & -- & -- & -- & -- & -- & -- & -- & -- \\
\hline & & $08-05-98$ & -- & -- & -- & -- & -- & -- & -- & -- & -- \\
\hline & & $03-19-99$ & -- & -- & -- & -- & -- & -- & $<.100$ & $<.090$ & $<.066$ \\
\hline & & $05-04-99$ & -- & -- & -- & -- & -- & -- & -- & -- & -- \\
\hline & & $07-08-99$ & -- & -- & -- & -- & -- & -- & -- & -- & -- \\
\hline & & $09-02-99$ & -- & -- & -- & -- & -- & -- & -- & -- & -- \\
\hline \multirow[t]{8}{*}{ GWMW10 } & $(\mathrm{A}-03-07) 07 \mathrm{CCD} 2$ & $07-09-97$ & $<5.00$ & $<5.00$ & $<5.00$ & $<30.0$ & $<5.00$ & $<5.00$ & $<.200$ & $<.200$ & $<.200$ \\
\hline & & $07-09-97$ & -- & -- & -- & -- & -- & -- & $<.200$ & $<.200$ & $<.200$ \\
\hline & & $01-28-98$ & -- & -- & -- & -- & -- & -- & -- & -- & -- \\
\hline & & $08-03-98$ & -- & -- & -- & -- & -- & -- & -- & -- & -- \\
\hline & & $03-16-99$ & -- & -- & -- & -- & -- & -- & $<.100$ & $<.090$ & $<.066$ \\
\hline & & $05-07-99$ & -- & -- & -- & -- & -- & -- & -- & -- & -- \\
\hline & & $07-09-99$ & -- & -- & -- & -- & -- & -- & -- & -- & -- \\
\hline & & $09-02-99$ & -- & -- & -- & -- & -- & -- & -- & -- & -- \\
\hline \multicolumn{2}{|c|}{ SEDIMENT RETENTION BASIN F } & $07-09-98$ & -- & -- & -- & -- & -- & -- & -- & -- & -- \\
\hline
\end{tabular}


Table 7. Water-chemistry and stormwater-sediment chemistry data, Grande Wash, Fort McDowell Indian Reservation, ArizonaContinued

\begin{tabular}{|c|c|c|c|c|c|c|c|c|c|c|c|}
\hline & & & $\begin{array}{c}1,1-D I- \\
\text { CHLORO- } \\
\text { ETHYL- } \\
\text { ENE }\end{array}$ & $\begin{array}{c}1,1,1- \\
\text { TRI- } \\
\text { CHLORO- } \\
\text { ETHANE }\end{array}$ & $\begin{array}{c}1,1,2- \\
\text { TRI- } \\
\text { CHLORO- } \\
\text { ETHANE }\end{array}$ & $\begin{array}{r}\text { ETHANE, } \\
1,1,2,2 \\
\text { TETRA- } \\
\text { CHLORO- } \\
\text { WAT UNF }\end{array}$ & $\begin{array}{l}\text { BENZO- } \\
\text { [GHI] - } \\
\text { PERY- } \\
\text { LENE }\end{array}$ & $\begin{array}{l}\text { BENZ (A) } \\
\text { ANTHRA- } \\
\text { CENE } \\
\text { WATER } \\
\text { UNFLTRD }\end{array}$ & $\begin{array}{l}\text { BENZENE } \\
\text { O-DI- } \\
\text { CHLORO- } \\
\text { WATER } \\
\text { UNFLTRD }\end{array}$ & $\begin{array}{l}1,2-D I- \\
\text { CHLORO- } \\
\text { PROPANE }\end{array}$ & $\begin{array}{l}\text { TRANS- } \\
1,2-D I- \\
\text { CHLORO- } \\
\text { ETHENE }\end{array}$ \\
\hline & LOCAL IDENTIFIER & DATE & $\begin{array}{l}\text { TOTAL } \\
\text { (UG/L) }\end{array}$ & $\begin{array}{l}\text { TOTAL } \\
\text { (UG/L) }\end{array}$ & $\begin{array}{l}\text { TOTAL } \\
\text { (UG/L) }\end{array}$ & $\begin{array}{c}\mathrm{REC} \\
(\mathrm{UG} / \mathrm{L})\end{array}$ & $\begin{array}{c}\text { TOTAL } \\
\text { (UG/L) }\end{array}$ & $\begin{array}{c}\mathrm{REC} \\
\text { (UG/L) }\end{array}$ & $\begin{array}{c}\mathrm{REC} \\
\text { (UG/L) }\end{array}$ & $\begin{array}{l}\text { TOTAL } \\
\text { (UG/L) }\end{array}$ & $\begin{array}{l}\text { TOTAL } \\
\text { (UG/L) }\end{array}$ \\
\hline \multirow[t]{4}{*}{ GRANDE } & WASH AT FOUNTAIN HILLS & $01-27-97$ & $<.800$ & $<.800$ & $<.800$ & $<.800$ & $<10.0$ & $<10.0$ & $<5.00$ & $<.800$ & $<.800$ \\
\hline & & $08-26-97$ & -- & -- & -- & -- & $<10.0$ & $<10.0$ & $<5.00$ & -- & -- \\
\hline & & $02-04-98$ & $<.088$ & $<.064$ & $<.128$ & $<.264$ & -- & -- & $<.096$ & $<.136$ & $<.064$ \\
\hline & & $07-14-99$ & -- & -- & -- & -- & -- & -- & -- & -- & -- \\
\hline \multirow[t]{7}{*}{ GWMW4A } & $(\mathrm{A}-03-06) 12 \mathrm{CCA} 1$ & $07-08-97$ & $<.200$ & $<.200$ & $<.200$ & $<.200$ & $<10.0$ & $<10.0$ & $<.200$ & $<.200$ & $<.200$ \\
\hline & & $01-29-98$ & $<.044$ & E.016 & $<.064$ & $<.132$ & -- & -- & $<.048$ & $<.068$ & $<.032$ \\
\hline & & $08-05-98$ & $<.044$ & $<.032$ & $<.064$ & $<.132$ & -- & -- & $<.048$ & $<.068$ & $<.032$ \\
\hline & & $03-18-99$ & $<.044$ & $<.032$ & $<.064$ & $<.130$ & -- & -- & $<.048$ & $<.068$ & $<.032$ \\
\hline & & $05-06-99$ & -- & -- & -- & -- & -- & -- & -- & -- & -- \\
\hline & & $07-07-99$ & -- & -- & -- & -- & -- & -- & -- & -- & -- \\
\hline & & $08-31-99$ & -- & -- & -- & -- & -- & -- & -- & -- & -- \\
\hline \multirow[t]{7}{*}{ GWMW5 ( } & $(A-03-06) 12 C D C$ & $07-08-97$ & $<.200$ & $<.200$ & $<.200$ & $<.200$ & $<10.0$ & $<10.0$ & $<.200$ & $<.200$ & $<.200$ \\
\hline & & $01-28-98$ & -- & -- & -- & -- & -- & -- & -- & -- & -- \\
\hline & & $08-05-98$ & -- & -- & -- & -- & -- & -- & -- & -- & -- \\
\hline & & $03-19-99$ & $<.044$ & $<.032$ & $<.064$ & $<.130$ & -- & -- & $<.048$ & $<.068$ & $<.032$ \\
\hline & & $05-04-99$ & -- & -- & -- & -- & -- & -- & -- & -- & -- \\
\hline & & $07-08-99$ & -- & -- & -- & -- & -- & -- & -- & -- & -- \\
\hline & & $09-02-99$ & -- & -- & -- & -- & -- & -- & -- & -- & -- \\
\hline \multirow[t]{8}{*}{ GWMW10 } & $(\mathrm{A}-03-07) 07 \mathrm{CCD} 2$ & $07-09-97$ & $<.200$ & $<.200$ & $<.200$ & $<.200$ & $<10.0$ & $<10.0$ & $<.200$ & $<.200$ & $<.200$ \\
\hline & & $07-09-97$ & $<.200$ & $<.200$ & $<.200$ & $<.200$ & -- & -- & $<.200$ & $<.200$ & $<.200$ \\
\hline & & $01-28-98$ & -- & -- & -- & -- & -- & -- & -- & -- & -- \\
\hline & & $08-03-98$ & -- & -- & -- & -- & -- & -- & -- & -- & -- \\
\hline & & $03-16-99$ & $<.044$ & $<.032$ & $<.064$ & $<.130$ & -- & -- & $<.048$ & $<.068$ & $<.032$ \\
\hline & & $05-07-99$ & -- & -- & -- & -- & -- & -- & -- & -- & -- \\
\hline & & $07-09-99$ & -- & -- & -- & -- & -- & -- & -- & -- & -- \\
\hline & & $09-02-99$ & -- & -- & -- & -- & -- & -- & -- & -- & -- \\
\hline \multirow[t]{7}{*}{ SEDIMENT } & NT RETENTION BASIN F & $07-09-98$ & -- & -- & -- & -- & -- & -- & -- & -- & -- \\
\hline & & & BENZENE & & BENZENE & BENZENE & & & & & \\
\hline & & & $1,2,4-$ & $1,2,5,6$ & $1,3-D I-$ & $1,4-\mathrm{DI}-$ & $2-$ & & & $\mathrm{DI}-\mathrm{N}-$ & \\
\hline & & & TRI- & -DIBENZ & CHLORO- & CHLORO- & CHLORO- & $2-$ & $2-$ & OCTYL & 2,4-DI- \\
\hline & & & $\begin{array}{l}\text { CHLORO- } \\
\text { WAT UNF }\end{array}$ & $\begin{array}{l}\text {-ANTHRA } \\
\text {-CENE }\end{array}$ & $\begin{array}{l}\text { WATER } \\
\text { UNFLTRD }\end{array}$ & $\begin{array}{l}\text { WATER } \\
\text { UNFLTRD }\end{array}$ & $\begin{array}{l}\text { NAPH- } \\
\text { THALENE }\end{array}$ & CHLORO- & NITRO- & PHTHAL- & CHLORO- \\
\hline & LOCAL IDENTIFIER & DATE & REC & TOTAL & REC & REC & TOTAL & TOTAL & TOTAL & TOTAL & TOTAL \\
\hline & & & (UG/L) & (UG/L) & (UG/L) & (UG/L) & (UG/L) & (UG/L) & (UG/L) & (UG/L) & (UG/L) \\
\hline \multirow[t]{4}{*}{ GRANDE } & WASH AT FOUNTAIN HILLS & $01-27-97$ & $<5.00$ & $<10.0$ & $<5.00$ & $<5.00$ & $<5.00$ & $<5.00$ & $<5.00$ & $<10.0$ & $<5.00$ \\
\hline & & $08-26-97$ & $<5.00$ & $<10.0$ & $<5.00$ & $<5.00$ & $<5.00$ & $<5.00$ & $<5.00$ & $<10.0$ & $<5.00$ \\
\hline & & $02-04-98$ & $<.376$ & -- & $<.108$ & $<.100$ & -- & -- & -- & -- & -- \\
\hline & & $07-14-99$ & -- & -- & -- & -- & -- & -- & -- & -- & -- \\
\hline \multirow[t]{7}{*}{ GWMW4A } & $(A-03-06) 12 \mathrm{CCA} 1$ & $07-08-97$ & $<.200$ & $<10.0$ & $<.200$ & $<.200$ & $<5.00$ & $<5.00$ & $<5.00$ & $<10.0$ & $<5.00$ \\
\hline & & $01-29-98$ & $<.188$ & -- & $<.054$ & $<.050$ & -- & -- & -- & -- & -- \\
\hline & & $08-05-98$ & $<.188$ & -- & $<.054$ & $<.050$ & -- & -- & -- & -- & -- \\
\hline & & $03-18-99$ & $<.190$ & -- & $<.054$ & E. 052 & -- & -- & -- & -- & -- \\
\hline & & $05-06-99$ & -- & -- & -- & -- & -- & -- & -- & -- & -- \\
\hline & & $07-07-99$ & -- & -- & -- & -- & -- & -- & -- & -- & -- \\
\hline & & $08-31-99$ & -- & -- & -- & -- & -- & -- & -- & -- & -- \\
\hline \multirow[t]{7}{*}{ GWMW5 ( } & $(A-03-06) 12 C D C$ & $07-08-97$ & $<.200$ & $<10.0$ & $<.200$ & $<.200$ & $<5.00$ & $<5.00$ & $<5.00$ & $<10.0$ & $<5.00$ \\
\hline & & $01-28-98$ & -- & -- & -- & -- & -- & -- & -- & -- & -- \\
\hline & & $08-05-98$ & -- & -- & -- & -- & -- & -- & -- & -- & -- \\
\hline & & $03-19-99$ & $<.190$ & -- & $<.054$ & E. 047 & -- & -- & -- & -- & -- \\
\hline & & $05-04-99$ & -- & -- & -- & -- & -- & -- & -- & -- & -- \\
\hline & & $07-08-99$ & -- & -- & -- & -- & -- & -- & -- & -- & -- \\
\hline & & $09-02-99$ & -- & -- & -- & -- & -- & -- & -- & -- & -- \\
\hline \multirow[t]{8}{*}{ GWMW10 } & $(A-03-07) 07 C C D 2$ & $07-09-97$ & $<.200$ & $<10.0$ & $<.200$ & $<.200$ & $<5.00$ & $<5.00$ & $<5.00$ & $<10.0$ & $<5.00$ \\
\hline & & $07-09-97$ & $<.200$ & -- & $<.200$ & $<.200$ & -- & -- & -- & -- & -- \\
\hline & & $01-28-98$ & -- & -- & -- & -- & -- & -- & -- & -- & -- \\
\hline & & $08-03-98$ & -- & -- & -- & -- & -- & -- & -- & -- & -- \\
\hline & & $03-16-99$ & $<.190$ & -- & $<.054$ & E.037 & -- & -- & -- & -- & -- \\
\hline & & $05-07-99$ & -- & -- & -- & -- & -- & -- & -- & -- & -- \\
\hline & & $07-09-99$ & -- & -- & -- & -- & -- & -- & -- & -- & -- \\
\hline & & $09-02-99$ & -- & -- & -- & -- & -- & -- & -- & -- & -- \\
\hline SEDIMEN & NT RETENTION BASIN F & $07-09-98$ & -- & -- & -- & -- & -- & -- & -- & -- & -- \\
\hline
\end{tabular}


Table 7. Water-chemistry and stormwater-sediment chemistry data, Grande Wash, Fort McDowell Indian Reservation, ArizonaContinued

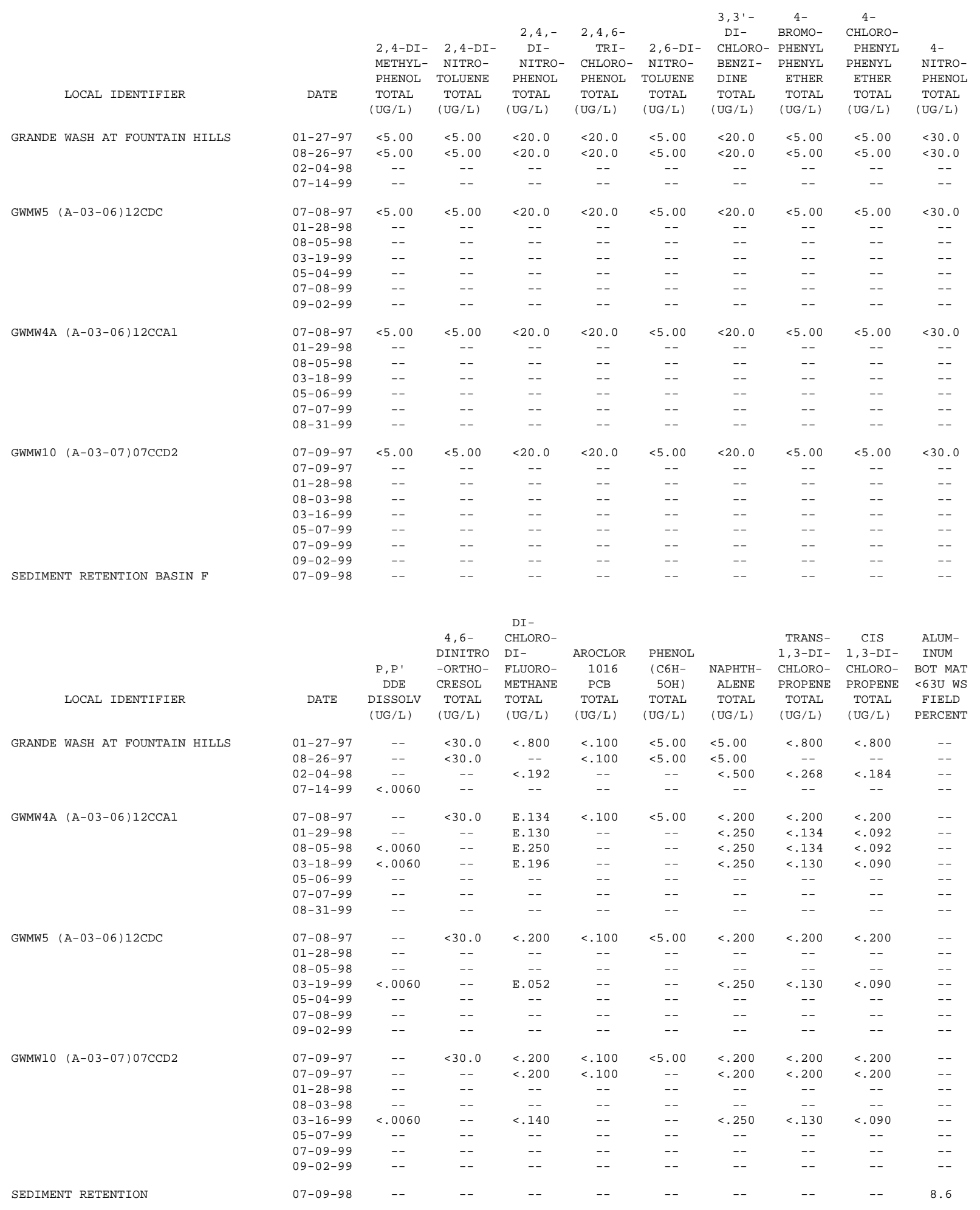


Table 7. Water-chemistry and stormwater-sediment chemistry data, Grande Wash, Fort McDowell Indian Reservation, ArizonaContinued

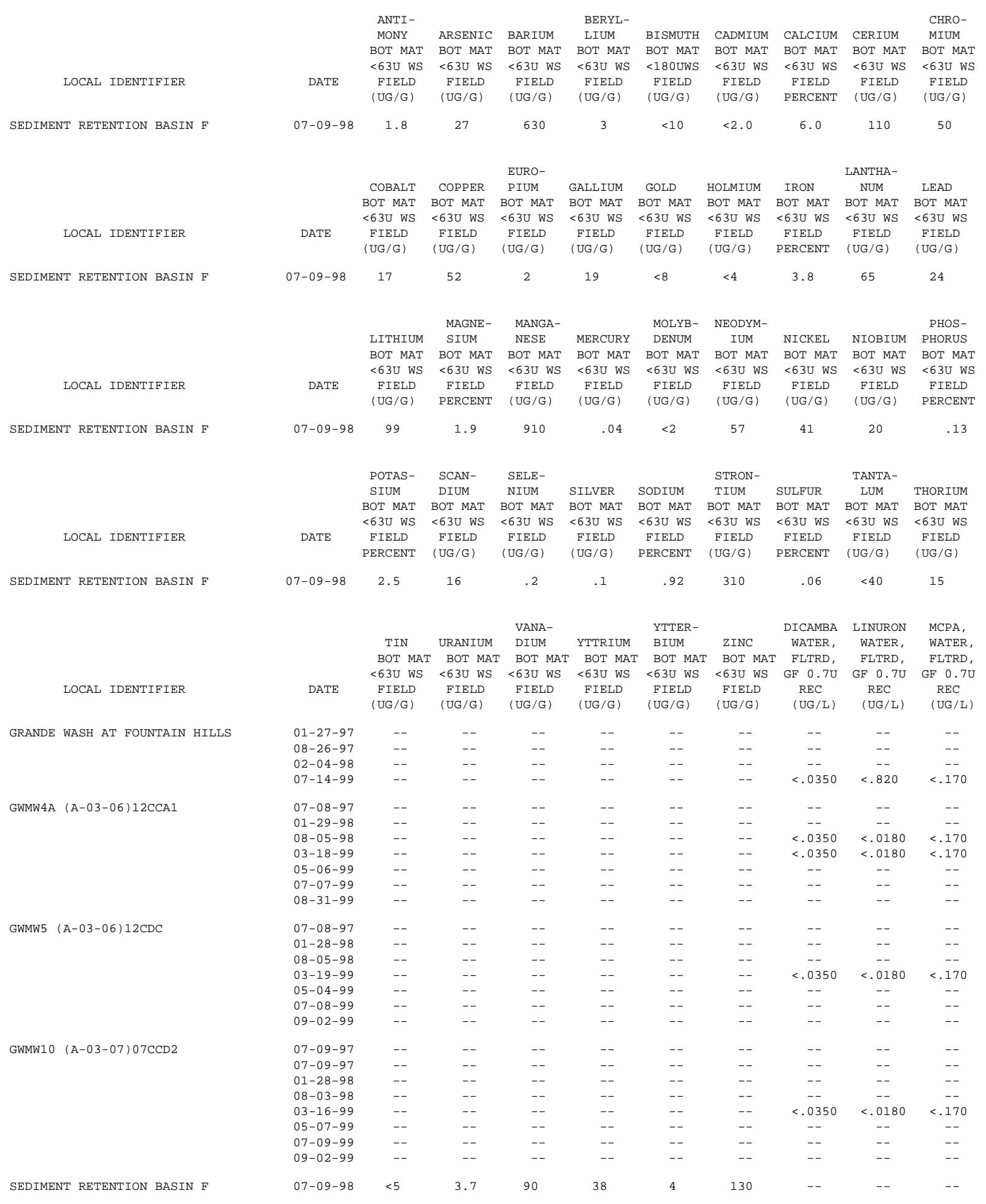


Table 7. Water-chemistry and stormwater-sediment chemistry data, Grande Wash, Fort McDowell Indian Reservation, ArizonaContinued

LOCAL IDENTIFIER

GRANDE WASH AT FOUNTAIN HILLS

GWMW4A $\quad(\mathrm{A}-03-06) 12 \mathrm{CCA} 1$

GWMW5 (A-03-06) 12CDC

GWMW10 (A-03-07) 07CCD2

LOCAL IDENTIFIER

GRANDE WASH AT FOUNTAIN HILLS

GWMW4A $\quad(\mathrm{A}-03-06) 12 \mathrm{CCA}$

GWMW5 (A-03-06) 12CDC

GWMW10 (A-03-07) 07CCD2

SEDIMENT RETENTION BASIN F

\begin{tabular}{|c|c|c|c|c|c|c|c|c|}
\hline ACPB， & $\begin{array}{l}\text { METHIO- } \\
\text { CARB, }\end{array}$ & $\begin{array}{c}\text { PRO- } \\
\text { POXUR, }\end{array}$ & $\begin{array}{l}\text { BENTA- } \\
\text { ZON, }\end{array}$ & $2,4-D B$ & $\begin{array}{l}\text { FLUO- } \\
\text { METURON }\end{array}$ & OXAMYL, & & \\
\hline WATER, & WATER, & WATER, & WATER, & WATER, & WATER, & WATER, & CHLOR- & PENTA- \\
\hline $\begin{array}{l}\text { FLTRD, } \\
\text { GF } 0.7 \mathrm{U}\end{array}$ & $\begin{array}{l}\text { FLTRD, } \\
\text { GF } 0.7 \mathrm{U}\end{array}$ & $\begin{array}{r}\text { FLTRD, } \\
\text { GF } 0.7 \mathrm{U}\end{array}$ & $\begin{array}{r}\text { FLTRD, } \\
\mathrm{GF} \quad 0.7 \mathrm{U}\end{array}$ & $\begin{array}{r}\text { FLTRD, } \\
\text { GF } 0.7 \mathrm{U}\end{array}$ & $\begin{array}{r}\text { FLTRD, } \\
\text { GF } 0.7 \mathrm{U}\end{array}$ & FLTRD, & PYRIFOS & CHLORO- \\
\hline REC & $\mathrm{REC}$ & REC & REC & REC & REC & $\mathrm{RE}$ & SOI & $\mathrm{AL}$ \\
\hline (UG/L) & (UG/L) & (UG/L) & (UG/L) & (UG/L) & (UG/L) & (UG/L) & (UG/L) & (UG/L \\
\hline
\end{tabular}
$\begin{array}{llllllllll}01-27-97 & -- & -- & -- & -- & -- & -- & -- & -- & <30.0 \\ 08-26-97 & -- & -- & -- & -- & -- & -- & -- & -- & <30.0\end{array}$ $02-04-98$ $07-14-99$

$<.--$

$<.0260<6.13$

$--$

$--$

$--$

$--$

.0350

07-08-97

$01-29-98$

$08-05-98$

$--$

$<.140$

$\begin{array}{ll}-- & -- \\ -- & --\end{array}$

$<.0260<.0350$

$\begin{array}{cc}-- & -- \\ -- & --\end{array}$

$<.0180 \quad 0350 \quad-$

$05-06-99$

$07-07-99$

$\begin{array}{lll}-- & -- & -- \\ -- & -- & --\end{array}$

08-31-99

07-08-97

$01-28-98$

$08-05-98$

$03-19-99$

05-04-99

$07-08-99$

09-02-99

--

$\begin{array}{lll}-- & -- & --\end{array}$

$--\quad-$

$<.140$

$<.0260<.0350$

--

$-$

$07-09-97$ 07-09-97

$01-28-98$

$08-03-98$

$03-16-99$

$05-07-99$

$07-09-99$

09-02-99

SEDIMENT RETENTION BASIN F 07-09-98

$--$

$$
-
$$

--
--
--
--
$<.140$
--
--
--

$--$

$--$

$<.0260$

$--$

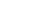

$\begin{array}{ll}-- & -- \\ -- & --\end{array}$

$\begin{array}{llll}-- & - & - & <\end{array}$

$<.0350<.0180<.0040 \quad-$

$\begin{array}{cccc}<.0350 & <.0180 & <.0040 & -- \\ -- & -- & -- & -\end{array}$

$\begin{array}{llll}-- & -- & -- & -- \\ -- & -- & -- & --\end{array}$

$--\quad \quad-$

$\begin{array}{llllll}-- & -- & -- & -- & -- & <30.0 \\ -- & -- & -- & -- & -- & --\end{array}$

$\begin{array}{llllll}-- & - & -- & -- & -- & - \\ - & -- & -- & -- & -\end{array}$

$<.0140<.240<.0350<.0180<.0040 \quad-$

$\begin{array}{llllll} & -- & -- & -- & -- & - \\ -- & -- & -- & -- & -- & -- \\ -- & -- & -- & -- & --\end{array}$

$\begin{array}{llllll}-- & -- & - & - & - & -\end{array}$
$<.0260<.0350$

$.0140<.240$

CHLOR- CHLOR- ALKA- BIS (2-

DANE DANE LINITY ETHYL DI-N- TRI-

$\begin{array}{clllllc}\text { DANE } & \text { DANE } & \text { LINITY } & \text { ETHYL } & \text { DI-N- } & & \text { TRI- } \\ \text { CIS } & \text { TRANS } & \text { WAT DIS } & \text { HEXYL) } & \text { BUTYL } & \text { VINYL } & \text { CHLORO- }\end{array}$

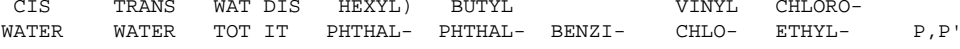

WHOLE WHOLE FIELD ATE ATE DINE RIDE RNE

DATE

(UG/L) (UG/L)

CACO3 TOTAL

TOTAL TOTAL
(UG/L)

TOTAL TOTAL

(UG/L) (UG/L) (UG/L)

01-27-97

$<.100<.100$

(UG/L)

$<40.0$

$<.800<.800$

(UG/L) $08-26-97$

$<.100<.100 \quad 390$

$\begin{array}{ll}<5.00 & <5.00 \\ <5.00 & <5.00\end{array}$

$<40.0<-800<.100$ $02-04-98$
$07-14-99$ $\begin{array}{llr}-- & -- & -- \\ -- & -- & 155\end{array}$

$-$

$\begin{array}{lllll}-- & -- & <.224 & <.076 & - \\ -- & -- & & -\end{array}$

$07-08-97$

$<.100<.100$

$01-29-98$ $08-05-98$ 03-18-99 $05-06-99$ $07-07-99$ $08-31-99$

$\begin{array}{ccc}.100 & <.100 & 340 \\ -- & -- & 347\end{array}$

$<5.00<5.00$

$<40.0$

$<.200<.200<.100$

$\begin{array}{llllll}.00 & <5.00 & <40.0 & <.200 & <.200 & <.100 \\ -- & -- & -- & <.112 & <.038 & - \\ -- & -- & -- & <.112 & <.038 & -\end{array}$

$--$

$--$

$-$

--

$--$

$07-08-97$ $01-28-98$ $08-05-98$

03-19-99

$03-19-99$

$07-08-99$

09-02-99

$<.100<.100$

$<5.00<5$.

$5.00<5.00$
--

$-$

$-$

$-$

$-$

$\begin{array}{ccccc}<.00<5.00<40.0 & <.200 & <.200 & <.100\end{array}$

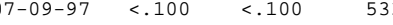
$07-09-97<.100<.100<-$ $\begin{array}{llll}01-28-98 & -- & -- & 542\end{array}$

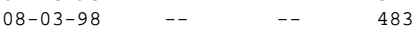
$\begin{array}{llll}08-16-99 & -- & -- & 517\end{array}$ $05-07-99$ $07-09-99$ 09-02-99

07-09-98 
Table 7. Water-chemistry and stormwater-sediment chemistry data, Grande Wash, Fort McDowell Indian Reservation, ArizonaContinued

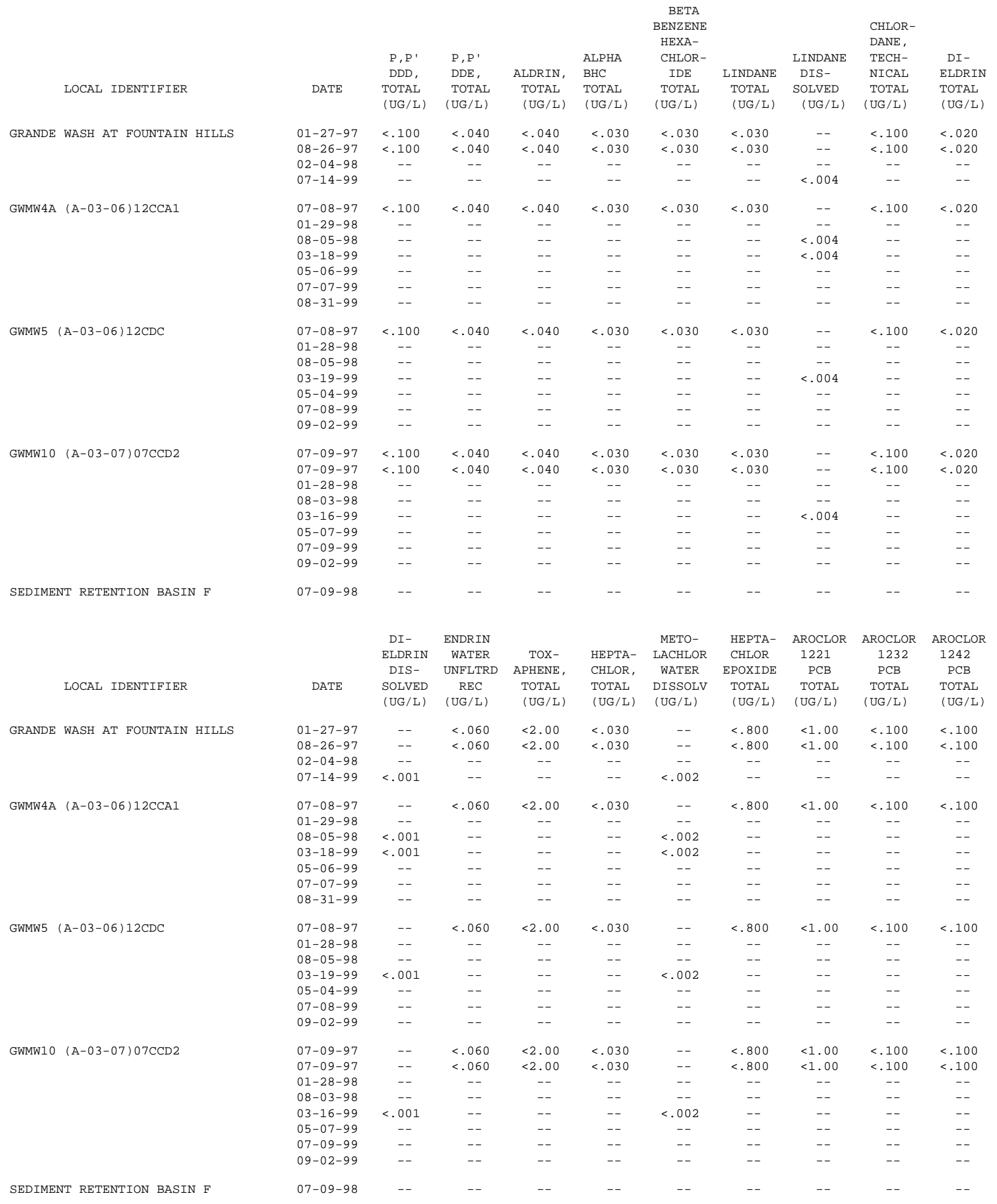


Table 7. Water-chemistry and stormwater-sediment chemistry data, Grande Wash, Fort McDowell Indian Reservation, ArizonaContinued

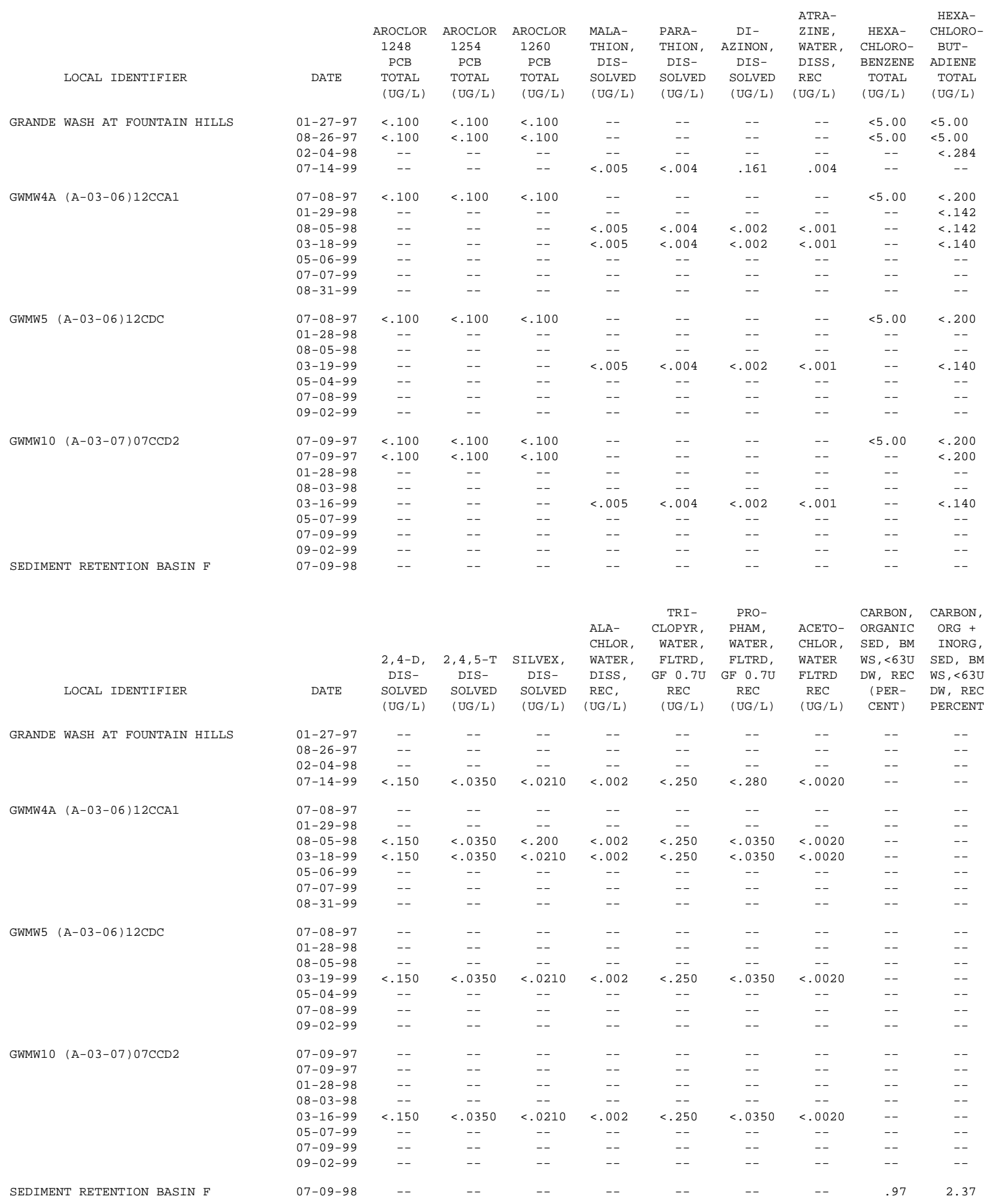


Table 7. Water-chemistry and stormwater-sediment chemistry data, Grande Wash, Fort McDowell Indian Reservation, ArizonaContinued

LOCAL IDENTIFIER

SEDIMENT RETENTION BASIN F

LOCAL IDENTIFIER

GRANDE WASH AT FOUNTAIN HILLS

GWMW4A $\quad(\mathrm{A}-03-06) 12 \mathrm{CCA}$

GWMW5 (A-03-06) 12CDC

GWMW10 (A-03-07) 07CCD2

LOCAI IDENTIFIER

GRANDE WASH AT FOUNTAIN HILLS

GWMW4A $\quad(\mathrm{A}-03-06) 12 \mathrm{CCA}$

GWMW5 (A-03-06) 12CDC

GWMW10 (A-03-07) 07CCD2

SEDIMENT RETENTION BASIN F

SEDIMENT RETENTION BASIN F

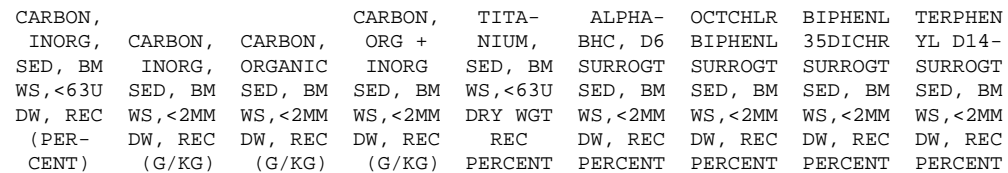

12.0

24.0

$.420 \quad 105$

88.

74.0

68.7

$\begin{array}{rrrrccccc}\text { BIPHENL } & \text { BENZENE } & \text { PIC- } & \text { ORY- } & \text { NORFLUR } & \text { NEB- } & \text { METH- } & \text { FEN- } & \\ \text { 2FLUORO } & \text { NITROD5 } & \text { LORAM, } & \text { ZALIN, } & \text { AZON, } & \text { URON, } & \text { OMYL, } & \text { URON, } & \\ \text { SURROGT } & \text { SURROGT } & \text { WATER, } & \text { WATER, } & \text { WATER, } & \text { WATER, } & \text { WATER, } & \text { WATER, } & \text { DNOC } \\ \text { SED, BM } & \text { SED, BM } & \text { FLTRD, } & \text { FLTRD, } & \text { FLTRD, } & \text { FLTRD, } & \text { FLTRD, } & \text { FLTRD, } & \text { WAT, FLT } \\ \text { WS, } \angle 2 M M & \text { WS, }<2 M M & \text { GF } 0.7 U & \text { GF } 0.7 U & \text { GF } 0.7 U & \text { GF } 0.7 U & \text { GF } 0.7 U & \text { GF } 0.7 U & \text { GF } 0.7 U \\ \text { DW, REC } & \text { DW, REC } & \text { REC } & \text { REC } & \text { REC } & \text { REC } & \text { REC } & \text { REC } & \text { REC }\end{array}$

DATE

DW, REC DW, REC

(UG/L) (UG/I) (UG/L) (UG/I)

01-27-97

$08-26-97$

02-04-98

07-14-99

07-08-97

$01-29-98$

$08-05-98$

$03-18-99$

$05-06-99$

$07-07-99$

08-31-99

$07-08-97$

$01-28-98$

$03-19-99$

$05-04-99$

$07-08-99$

$09-02-99$

$07-09-97$

$07-09-97$

$01-28-98$
$08-03-98$

$03-16-99$

$05-07-99$

$07-09-99$

$09-02-99$

$07-09-98$

$\begin{array}{cc}-- & - \\ -- & - \\ -- & - \\ <.0500 & .960\end{array}$

$\begin{array}{cc}-- & -- \\ -- & -- \\ -- & -- \\ <.0240 & <.0150\end{array}$

--
--
--

$\begin{array}{cc}-- & -- \\ -- & -- \\ -- & -- \\ <.760 & <.420\end{array}$

$--$

$--$

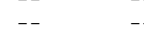

$--$

$--$

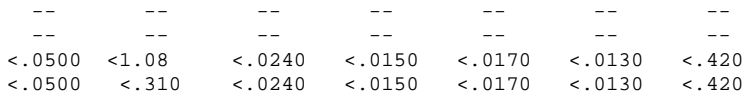

$<\begin{aligned} & <.0240<.0150<.0170<.0130<.420 \\ & <.0800<.0240<.0150<.0170<.0130<.420\end{aligned}$

$\begin{array}{ccccccc}-- & -- & -- & -- & -- & -- & -- \\ -- & -- & -- & -- & -- & -- & --\end{array}$

$--\quad--$

$--\quad--$

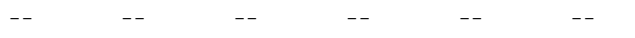

$\begin{array}{lllllll}-- & -- & -- & -- & -- & -- & - \\ -- & -- & -- & -- & -- & -- & - \\ -- & -- & -- & -- & -- & -- & -\end{array}$

$<.0500<.310<.0240<.0150<.0170<.0130<.420$

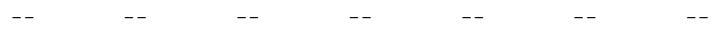

$\begin{array}{lllllll}-- & -- & -- & -- & -- & -- & - \\ -- & -- & -- & -- & -- & -- & - \\ -- & -- & -- & -- & -- & -- & -\end{array}$

$\begin{array}{ll}-- & -- \\ -- & -7\end{array}$

$\begin{array}{ccccccc}-- & -- & -- & -- & -- & -- & -- \\ <.0500 & <.310 & <.0240 & <.0150 & <.0170 & <.0130 & <.420\end{array}$

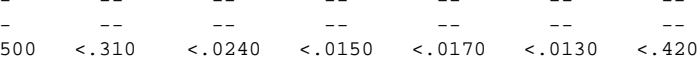

$\begin{array}{lllllll}-- & -- & -- & -- & -- & -- & -- \\ -- & -- & -- & -- & -- & -- & - \\ - & -- & -- & -- & -- & - & -\end{array}$

57.4

63.1

\begin{tabular}{|c|c|c|c|c|c|c|c|c|}
\hline $\begin{array}{l}\text { DIURON, } \\
\text { WATER, } \\
\text { FLTRD, }\end{array}$ & $\begin{array}{l}\text { DINOSEB } \\
\text { WATER, } \\
\text { FLTRD, }\end{array}$ & $\begin{array}{l}\text { DICHLOR } \\
\text { PROP, } \\
\text { WATER, } \\
\text { FLTRD, }\end{array}$ & $\begin{array}{l}\text { DICHLO- } \\
\text { BENIL, } \\
\text { WATER, } \\
\text { FLTRD, }\end{array}$ & $\begin{array}{c}\text { DACTHAL } \\
\text { MONO- } \\
\text { ACID, } \\
\text { WAT, FLT }\end{array}$ & $\begin{array}{l}\text { CLOPYR- } \\
\text { ALID, } \\
\text { WATER, } \\
\text { FLTRD, }\end{array}$ & $\begin{array}{c}\text { CHLORO- } \\
\text { THALO- } \\
\text { NIL, } \\
\text { WAT, FLT }\end{array}$ & $\begin{array}{l}\text { CHLOR- } \\
\text { AMBEN, } \\
\text { WATER, } \\
\text { FLTRD, }\end{array}$ & $\begin{array}{c}\text { 3HYDRXY } \\
\text { CARBO- } \\
\text { FURAN } \\
\text { WAT, FLT }\end{array}$ \\
\hline GF $0.7 \mathrm{U}$ & $\mathrm{GF} \quad 0.7 \mathrm{U}$ & $\mathrm{GF} \quad 0.7 \mathrm{U}$ & GF $0.7 \mathrm{U}$ & GF $\quad 0.7 \mathrm{U}$ & GF $0.7 \mathrm{U}$ & $\mathrm{GF} \quad 0.7 \mathrm{U}$ & GF $0.7 \mathrm{U}$ & GF $\quad 0.7 \mathrm{U}$ \\
\hline $\begin{array}{l}\text { REC } \\
(\mathrm{UG} / \mathrm{L})\end{array}$ & $\begin{array}{l}\text { REC } \\
(\mathrm{UG} / \mathrm{L})\end{array}$ & $\begin{array}{l}\text { REC } \\
(\mathrm{UG} / \mathrm{L})\end{array}$ & $\begin{array}{l}\text { REC } \\
(\mathrm{UG} / \mathrm{L})\end{array}$ & $\begin{array}{l}\text { REC } \\
(\mathrm{UG} / \mathrm{L})\end{array}$ & $\begin{array}{l}\text { REC } \\
(\mathrm{UG} / \mathrm{L})\end{array}$ & $\begin{array}{l}\text { REC } \\
(\mathrm{UG} / \mathrm{L})\end{array}$ & $\begin{array}{l}\text { REC } \\
(\mathrm{UG} / \mathrm{L})\end{array}$ & $\begin{array}{l}\text { REC } \\
(\mathrm{UG} / \mathrm{L})\end{array}$ \\
\hline
\end{tabular}

DATE $\begin{array}{lllllllll}(\mathrm{UG} / \mathrm{L}) & (\mathrm{UG} / \mathrm{L}) & \text { (UG/L) } & \text { (UG/L) } & \text { (UG/L) } & \text { (UG/L) } & \text { (UG/L) } & \text { (UG/L) } & \text { (UG/L) }\end{array}$

$01-27-97$

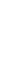

$02-04-98$

07-14-99

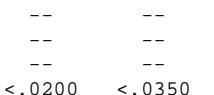

$\begin{array}{llll}-- & -- & -- & -- \\ -- & -- & -- & -- \\ -- & -- & -- & -- \\ <.0320 & <1.20 & <.150 & <.230\end{array}$

--
--
--
$<.480$

$\begin{array}{ll}-- & -- \\ -- & -- \\ -- & -- \\ <.420 & <.690\end{array}$

07-08-97

$01-29-98$

$08-05-98$

$03-18-99$

$05-06-99$

$07-07-99$
$08-31-99$

$\begin{array}{llll}-- & -- & --\end{array}$

$<.150<<.230$

$<.480$

$<.690$

$\begin{array}{cccccc}-- & -- & -- & -- & -- & -- \\ <.0200 & <.0350 & <-0320 & <-- & -- & -- \\ <.0200 & <.0350 & <.0320 & <1.20 & <.0170 & <.230\end{array}$

$<.0200<.0350<.0320<1.20<.0170<.230<.480<.420<.0140$ $\begin{array}{cccccccc}<.0200 & <.0350<.0320<1.20<.0170<.230 & <.480 & <.420<.0140\end{array}$

$07-08-97$

$01-28-98$

$08-05-98$

$03-19-99$

$05-04-99$

07-08-99

09-02-99

07-09-97

$07-09-97$
$01-28-98$

$08-03-98$

$03-16-99$

03-16-99

05-07-99

09-02-99

07-09-98
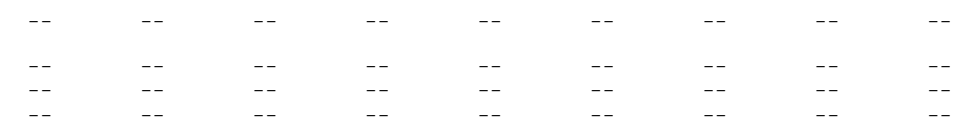

$<.0200<.0350<.0320<1.20<.0170<.230<.480<.420<.0140$

$\begin{array}{lllllllll}-- & -- & -- & -- & -- & -- & -- & -- & -- \\ -- & -- & -- & -- & -- & -- & -- & -- & --\end{array}$

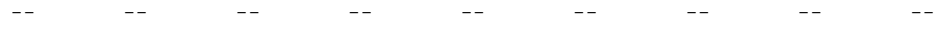

$\begin{array}{lllllllll}-- & -- & -- & -- & -- & -- & -- & -- & - \\ -- & -- & -- & -- & -- & -- & -- & -- & - \\ -- & -- & -- & -- & -- & -- & -- & -- & -\end{array}$

$\begin{array}{ccccccccc}-- & -- & -- & -- & -- & -- & -- & -- & -- \\ -.0200 & <.0350 & <-0 & -- & -- & -- & -- & -- & -- \\ -.0320 & <1.20 & <.0170 & <.230 & <.480 & <.420 & <.0140\end{array}$

$\begin{array}{lllllllll}-- & -- & -- & -- & -- & -- & -- & -- & -- \\ -- & -- & -- & -- & -- & -- & -- & -- & -- \\ -- & -- & -- & -- & -- & -- & -- & -- & --\end{array}$ 
Table 7. Water-chemistry and stormwater-sediment chemistry data, Grande Wash, Fort McDowell Indian Reservation, ArizonaContinued

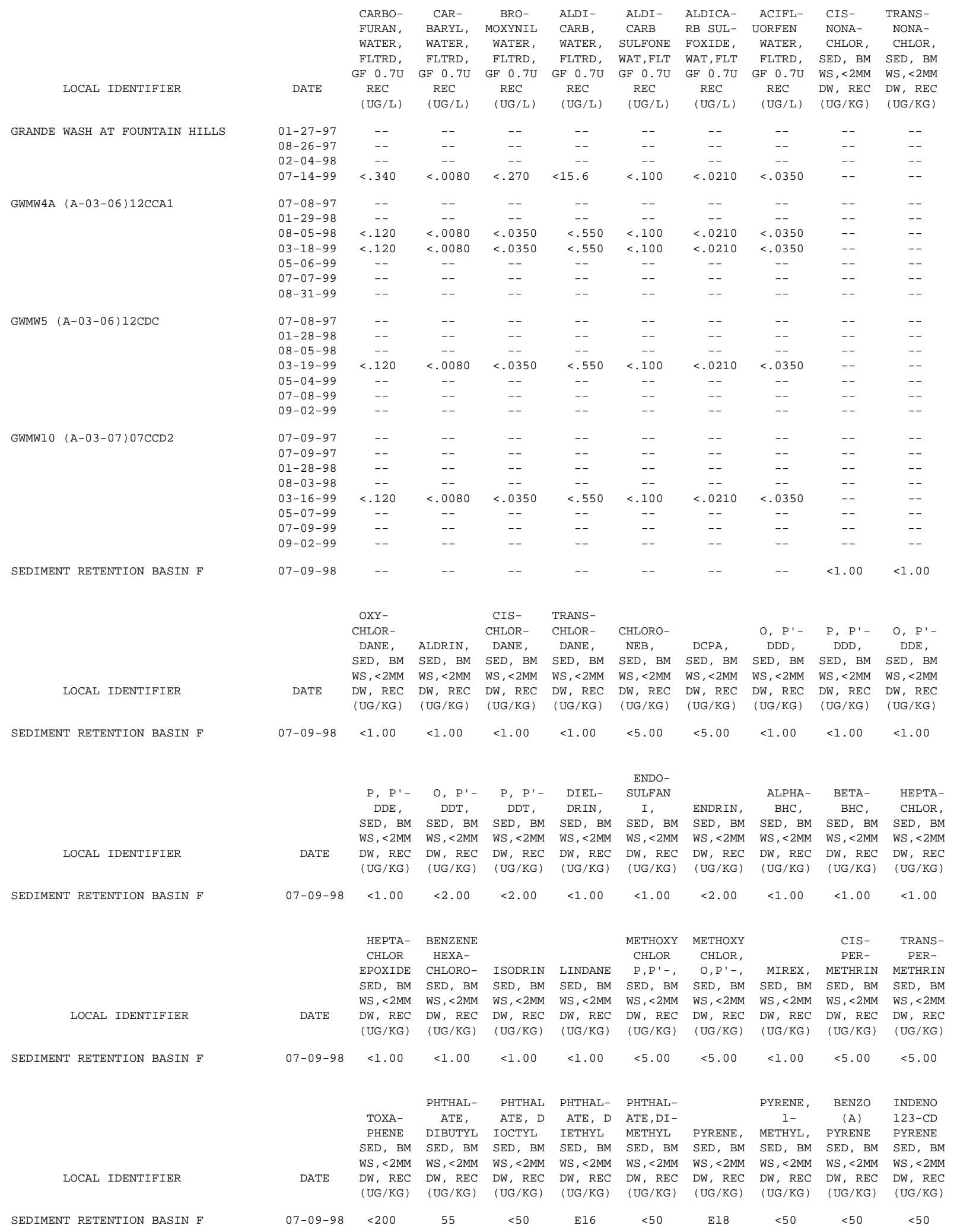


Table 7. Water-chemistry and stormwater-sediment chemistry data, Grande Wash, Fort McDowell Indian Reservation, ArizonaContinued

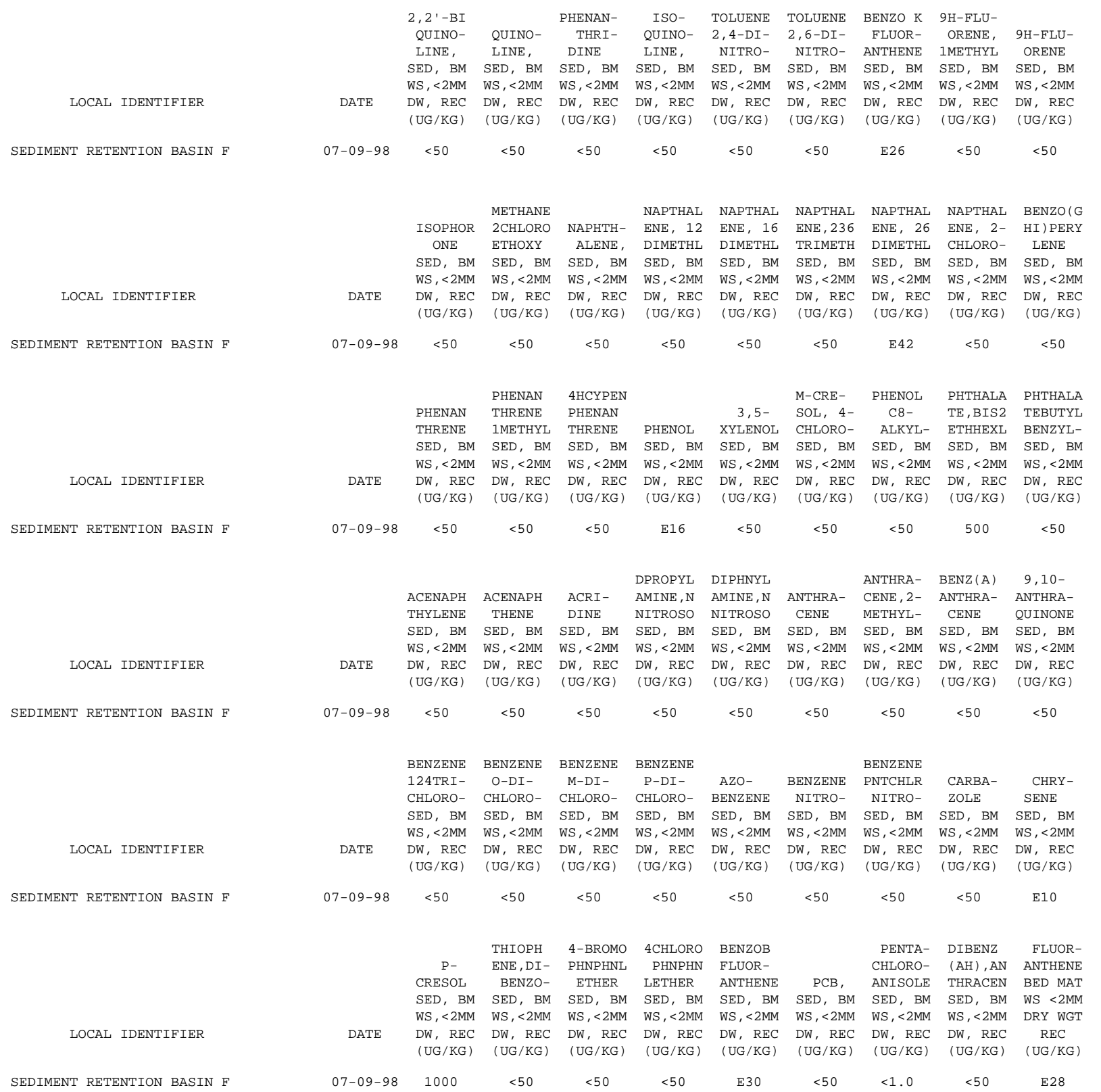


Table 7. Water-chemistry and stormwater-sediment chemistry data, Grande Wash, Fort McDowell Indian Reservation, ArizonaContinued

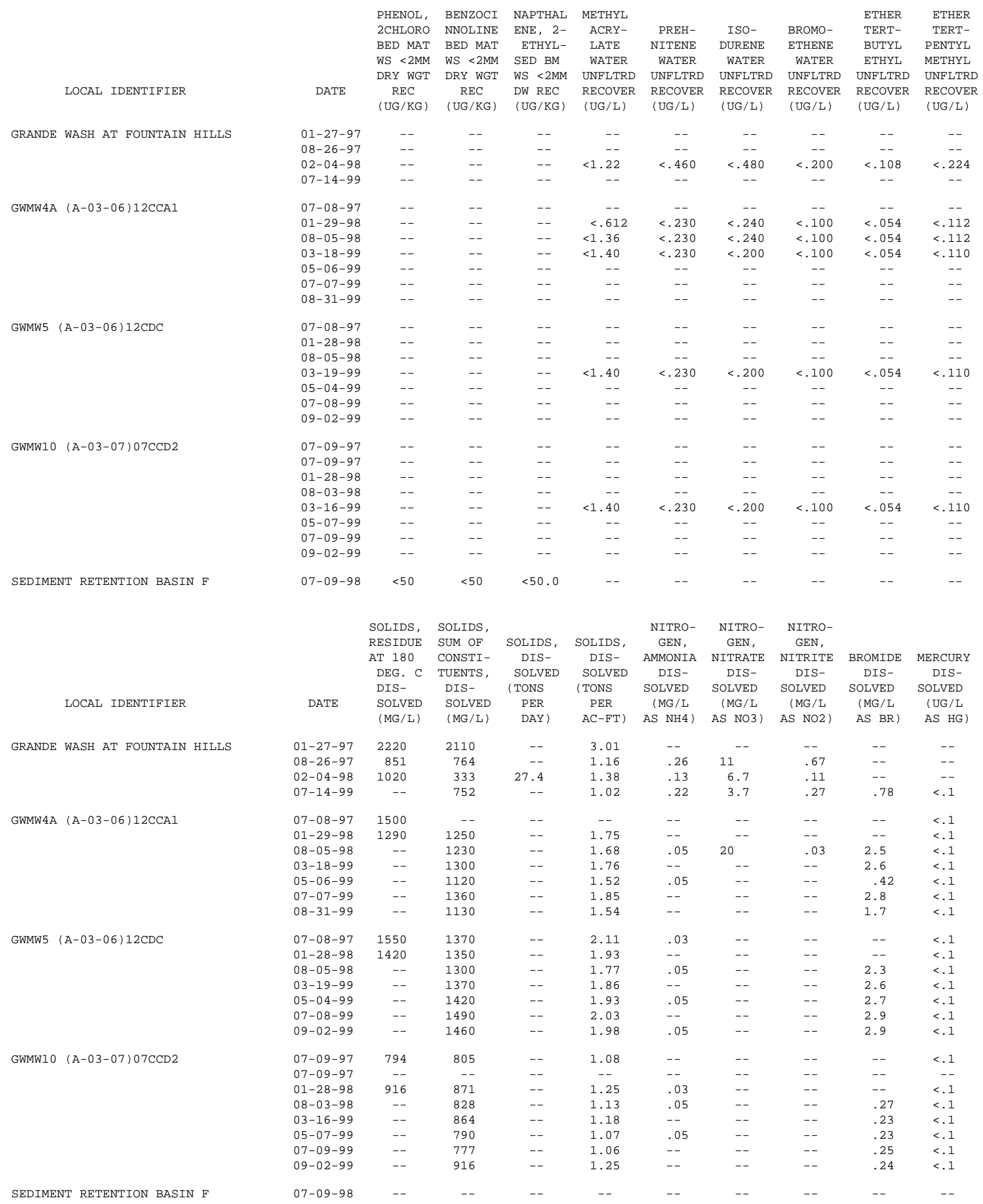


Table 7. Water-chemistry and stormwater-sediment chemistry data, Grande Wash, Fort McDowell Indian Reservation, ArizonaContinued

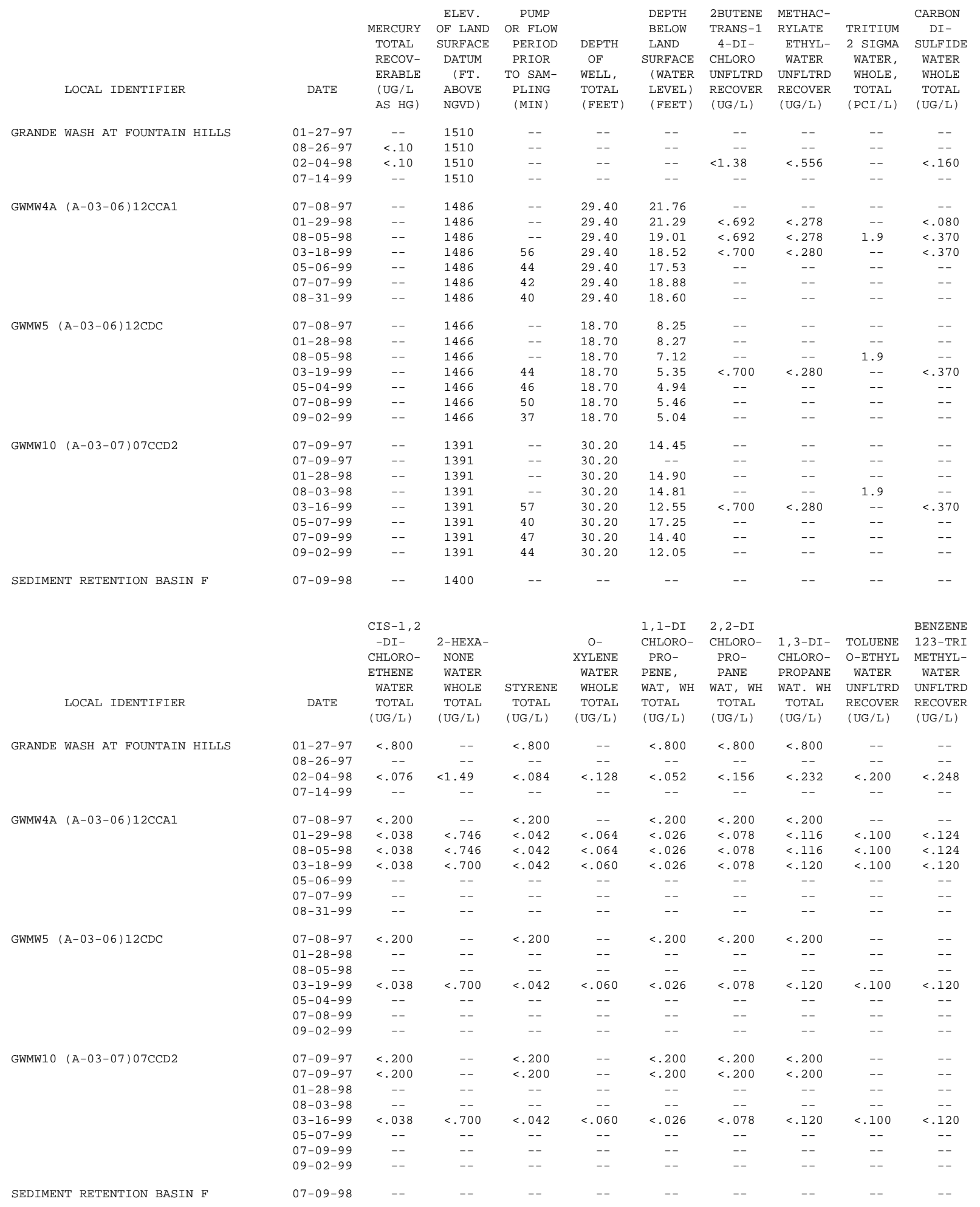


Table 7. Water-chemistry and stormwater-sediment chemistry data, Grande Wash, Fort McDowell Indian Reservation, ArizonaContinued

\begin{tabular}{|c|c|c|c|c|c|c|c|c|c|c|c|}
\hline & & & & ISO- & & BENZENE & $0-$ & & METHANE & & BENZENE \\
\hline & & & BENZENE & PROPYL- & BENZENE & 135-TRI & CHLORO- & TOLUENE & BROMO & BENZENE & $\mathrm{SEC}$ \\
\hline & & & 124-TRI & BENZENE & $\mathrm{N}-\mathrm{PROPY}$ & METHYL & TOLUENE & $\mathrm{P}-\mathrm{CHLOR}$ & CHLORO- & N-BUTYL & BUTYL- \\
\hline & & & METHYL & WATER & WATER & WATER & WATER & WATER & WAT & WATER & WATER \\
\hline & & & UNFILT & WHOLE & UNFLTRD & UNFLTRD & WHOLE & UNFLTRD & UNFLTRD & UNFLTRD & UNFLTRD \\
\hline & LOCAL IDENTIFIER & DATE & $\begin{array}{l}\text { RECOVER } \\
(\mathrm{UG} / \mathrm{L})\end{array}$ & $\begin{array}{c}\mathrm{REC} \\
(\mathrm{UG} / \mathrm{L})\end{array}$ & $\begin{array}{c}\mathrm{REC} \\
\text { (UG/L) }\end{array}$ & $\begin{array}{c}\mathrm{REC} \\
(\mathrm{UG} / \mathrm{L})\end{array}$ & $\begin{array}{l}\text { TOTAL } \\
\text { (UG/L) }\end{array}$ & $\begin{array}{c}\mathrm{REC} \\
\text { (UG/L) }\end{array}$ & $\begin{array}{c}\mathrm{REC} \\
\text { (UG/L) }\end{array}$ & $\begin{array}{c}\text { REC } \\
\text { (UG/L) }\end{array}$ & $\begin{array}{c}\mathrm{REC} \\
(\mathrm{UG} / \mathrm{L})\end{array}$ \\
\hline GRANDE & WASH AT FOUNTAIN HILLS & $01-27-97$ & $<.800$ & $<.800$ & $<.800$ & $<.800$ & $<.800$ & $<.800$ & $<.800$ & $<.800$ & $<.800$ \\
\hline & & $08-26-97$ & -- & -- & -- & -- & -- & -- & -- & -- & -- \\
\hline & & $02-04-98$ & E. 024 & $<.064$ & $<.084$ & $<.088$ & $<.084$ & $<.112$ & $<.088$ & $<.372$ & $<.096$ \\
\hline & & $07-14-99$ & -- & -- & -- & -- & -- & -- & -- & -- & -- \\
\hline GWMW4A & $(A-03-06) 12 \mathrm{CCA} 1$ & $07-08-97$ & $<.200$ & $<.200$ & $<.200$ & $<.200$ & $<.200$ & $<.200$ & $<.200$ & $<.200$ & $<.200$ \\
\hline & & $01-29-98$ & E.011 & $<.032$ & $<.042$ & $<.044$ & $<.042$ & $<.056$ & $<.044$ & $<.186$ & $<.048$ \\
\hline & & $08-05-98$ & $<.056$ & $<.032$ & $<.042$ & $<.044$ & $<.042$ & $<.056$ & $<.044$ & $<.186$ & $<.048$ \\
\hline & & $03-18-99$ & $<.056$ & $<.032$ & $<.042$ & $<.044$ & $<.042$ & $<.056$ & $<.044$ & $<.190$ & $<.048$ \\
\hline & & $05-06-99$ & -- & -- & -- & -- & -- & -- & -- & -- & -- \\
\hline & & $07-07-99$ & -- & -- & -- & -- & -- & -- & -- & -- & -- \\
\hline & & $08-31-99$ & -- & -- & -- & -- & -- & -- & -- & -- & -- \\
\hline GWMW5 & $(\mathrm{A}-03-06) 12 \mathrm{CDC}$ & $07-08-97$ & $<.200$ & $<.200$ & $<.200$ & $<.200$ & $<.200$ & $<.200$ & $<.200$ & $<.200$ & $<.200$ \\
\hline & & $01-28-98$ & -- & -- & -- & -- & -- & -- & -- & -- & -- \\
\hline & & $08-05-98$ & -- & -- & -- & -- & -- & -- & -- & -- & -- \\
\hline & & $03-19-99$ & $<.056$ & $<.032$ & $<.042$ & $<.044$ & $<.042$ & $<.056$ & $<.044$ & $<.190$ & $<.048$ \\
\hline & & $05-04-99$ & -- & -- & -- & -- & -- & -- & -- & -- & -- \\
\hline & & $07-08-99$ & -- & -- & -- & -- & -- & -- & -- & -- & -- \\
\hline & & $09-02-99$ & -- & -- & -- & -- & -- & -- & -- & -- & -- \\
\hline GWMW10 & $(A-03-07) 07 C C D 2$ & $07-09-97$ & $<.200$ & $<.200$ & $<.200$ & $<.200$ & $<.200$ & $<.200$ & $<.200$ & $<.200$ & $<.200$ \\
\hline & & $07-09-97$ & $<.200$ & $<.200$ & $<.200$ & $<.200$ & $<.200$ & $<.200$ & $<.200$ & $<.200$ & $<.200$ \\
\hline & & $01-28-98$ & -- & -- & -- & -- & -- & -- & -- & -- & -- \\
\hline & & $08-03-98$ & -- & -- & -- & -- & -- & -- & -- & -- & -- \\
\hline & & $03-16-99$ & $<.056$ & $<.032$ & $<.042$ & $<.044$ & $<.042$ & $<.056$ & $<.044$ & $<.190$ & $<.048$ \\
\hline & & $05-07-99$ & -- & -- & -- & -- & -- & -- & -- & -- & -- \\
\hline & & $07-09-99$ & -- & -- & -- & -- & -- & -- & -- & -- & -- \\
\hline & & $09-02-99$ & -- & -- & -- & -- & -- & -- & -- & -- & -- \\
\hline SEDIMEN & NT RETENTION BASIN F & $07-09-98$ & -- & -- & -- & -- & -- & -- & -- & -- & -- \\
\hline & & & BENZENE & P-ISO- & & $123-\mathrm{TRI}$ & ETHANE, & $1,2,3-$ & $1,2-$ & & METHYL \\
\hline & & & TERT- & PROPYL- & METHYL & CHLORO- & $1112-$ & TRI- & DIBROMO & FREON- & TERT- \\
\hline & & & BUTYL- & TOLUENE & IODIDE & PROPANE & TETRA- & CHLORO & ETHANE & 113 & BUTYL \\
\hline & & & WATER & WATER & WATER & WATER & CHLORO- & BENZENE & WATER & WATER & ETHER \\
\hline & & & UNFLTRD & WHOLE & UNF LTRD & WHOLE & WAT UNF & WAT, WH & WHOLE & UNFLTRD & WAT UNF \\
\hline & LOCAL IDENTIFIER & DATE & REC & REC & RECOVER & TOTAL & REC & REC & TOTAL & REC & REC \\
\hline & & & & & & & & & & & \\
\hline GRANDE & WASH AT FOUNTAIN HILLS & $01-27-97$ & $<.800$ & $<.800$ & -- & $<.800$ & $<.800$ & $<.800$ & $<.800$ & $<.800$ & $<.800$ \\
\hline & & $08-26-97$ & -- & -- & -- & -- & -- & -- & -- & -- & -- \\
\hline & & $02-04-98$ & $<.192$ & E. 010 & $<.152$ & $<.140$ & $<.088$ & $<.532$ & $<.072$ & $<.064$ & $<.224$ \\
\hline & & $07-14-99$ & -- & -- & -- & -- & -- & -- & -- & -- & -- \\
\hline GWMW4A & $(A-03-06) 12 \mathrm{CCA} 1$ & $07-08-97$ & $<.200$ & $<.200$ & -- & $<.200$ & $<.200$ & $<.200$ & $<.200$ & $<.200$ & $<.200$ \\
\hline & & $01-29-98$ & $<.096$ & $<.110$ & $<.076$ & $<.070$ & $<.044$ & $<.266$ & $<.036$ & $<.032$ & $<.112$ \\
\hline & & $08-05-98$ & $<.096$ & $<.110$ & $<.208$ & $<.162$ & $<.044$ & $<.266$ & $<.036$ & $<.032$ & $<.166$ \\
\hline & & $03-18-99$ & $<.100$ & $<.110$ & $<.210$ & $<.160$ & $<.044$ & $<.270$ & $<.036$ & $<.032$ & $<.170$ \\
\hline & & $05-06-99$ & -- & -- & -- & -- & -- & -- & -- & -- & -- \\
\hline & & $07-07-99$ & -- & -- & -- & -- & -- & -- & -- & -- & -- \\
\hline & & $08-31-99$ & -- & -- & -- & -- & -- & -- & -- & -- & -- \\
\hline GWMW5 & $(\mathrm{A}-03-06) 12 \mathrm{CDC}$ & $07-08-97$ & $<.200$ & $<.200$ & -- & $<.200$ & $<.200$ & $<.200$ & $<.200$ & $<.200$ & $<.200$ \\
\hline & & $01-28-98$ & -- & -- & -- & -- & -- & -- & -- & -- & -- \\
\hline & & $08-05-98$ & -- & -- & -- & -- & -- & -- & -- & -- & -- \\
\hline & & $03-19-99$ & $<.100$ & $<.110$ & $<.210$ & $<.160$ & $<.044$ & $<.270$ & $<.036$ & $<.032$ & $<.170$ \\
\hline & & $05-04-99$ & -- & -- & -- & -- & -- & -- & -- & -- & -- \\
\hline & & $07-08-99$ & -- & -- & -- & -- & -- & -- & -- & -- & -- \\
\hline & & $09-02-99$ & -- & -- & -- & -- & -- & -- & -- & -- & -- \\
\hline GWMW10 & $(A-03-07) 07 C C D 2$ & $07-09-97$ & $<.200$ & $<.200$ & -- & $<.200$ & $<.200$ & $<.200$ & $<.200$ & $<.200$ & $<.200$ \\
\hline & & $07-09-97$ & $<.200$ & $<.200$ & -- & $<.200$ & $<.200$ & $<.200$ & $<.200$ & $<.200$ & $<.200$ \\
\hline & & $01-28-98$ & -- & -- & -- & -- & -- & -- & -- & -- & -- \\
\hline & & $08-03-98$ & -- & -- & -- & -- & -- & -- & -- & -- & -- \\
\hline & & $03-16-99$ & $<.100$ & $<.110$ & $<.210$ & $<.160$ & $<.044$ & $<.270$ & $<.036$ & $<.032$ & $<.170$ \\
\hline & & $05-07-99$ & -- & -- & -- & -- & -- & -- & -- & -- & -- \\
\hline & & $07-09-99$ & -- & -- & -- & -- & -- & -- & -- & -- & -- \\
\hline & & $09-02-99$ & -- & -- & -- & -- & -- & -- & -- & -- & -- \\
\hline SEDIMEN & NT RETENTION BASIN F & $07-09-98$ & -- & -- & -- & -- & -- & -- & -- & -- & -- \\
\hline
\end{tabular}


Table 7. Water-chemistry and stormwater-sediment chemistry data, Grande Wash, Fort McDowell Indian Reservation, ArizonaContinued

\begin{tabular}{|c|c|c|c|c|c|c|c|c|c|c|c|}
\hline & LOCAL IDENTIFIER & DATE & $\begin{array}{l}\text { PROPENE } \\
3- \\
\text { CHLORO- } \\
\text { WATER } \\
\text { UNFLTRD } \\
\text { RECOVER } \\
\text { (UG/L) }\end{array}$ & $\begin{array}{l}\text { METHYL } \\
\text { ISO- } \\
\text { BUTYL } \\
\text { KETONE } \\
\text { WAT.WH. } \\
\text { TOTAL } \\
\text { (UG/L) }\end{array}$ & $\begin{array}{l}\text { SEDI- } \\
\text { MENT, } \\
\text { SUS- } \\
\text { PENDED } \\
(\text { MG/L) }\end{array}$ & $\begin{array}{c}\text { XYLENE } \\
\text { WATER } \\
\text { UNFLTRD } \\
\text { REC } \\
\text { (UG/L) }\end{array}$ & $\begin{array}{c}\text { ACETONE } \\
\text { WATER } \\
\text { WHOLE } \\
\text { TOTAL } \\
\text { (UG/L) }\end{array}$ & $\begin{array}{l}\text { BROMO- } \\
\text { BENZENE } \\
\text { WATER, } \\
\text { WHOLE, } \\
\text { TOTAL } \\
(\text { UG/L) }\end{array}$ & $\begin{array}{l}\text { ETHER } \\
\text { ETHYL } \\
\text { WATER } \\
\text { UNFLTRD } \\
\text { RECOVER } \\
\text { (UG/L) }\end{array}$ & $\begin{array}{l}\text { DI-ISO- } \\
\text { PROPYL- } \\
\text { ETHER, } \\
\text { WATER, } \\
\text { UNFLTRD } \\
\text { RECOVER } \\
(\text { UG/L) }\end{array}$ & $\begin{array}{c}\text { METH- } \\
\text { ACRYLO- } \\
\text { NITRITE } \\
\text { WATER } \\
\text { UNFLTRD } \\
\text { RECOVER } \\
\text { (UG/L) }\end{array}$ \\
\hline \multirow[t]{4}{*}{ GRANDE } & WASH AT FOUNTAIN HILLS & $01-27-97$ & -- & -- & -- & $<.800$ & -- & $<.800$ & -- & -- & -- \\
\hline & & $08-26-97$ & -- & -- & -- & -- & -- & -- & -- & -- & -- \\
\hline & & $02-04-98$ & $<.392$ & $<.748$ & -- & -- & $<4.90$ & $<.072$ & $<.340$ & $<.196$ & $<1.14$ \\
\hline & & $07-14-99$ & -- & -- & 20 & -- & -- & -- & -- & -- & -- \\
\hline \multirow[t]{7}{*}{ GWMW4A } & $(A-03-06) 12 \mathrm{CCA} 1$ & $07-08-97$ & -- & -- & -- & $<.200$ & -- & $<.200$ & -- & -- & -- \\
\hline & & $01-29-98$ & $<.196$ & $<.374$ & -- & -- & $<4.90$ & $<.036$ & $<.170$ & $<.098$ & $<.570$ \\
\hline & & $08-05-98$ & $<.196$ & $<.374$ & -- & -- & $<4.90$ & $<.036$ & $<.170$ & $<.098$ & $<.570$ \\
\hline & & $03-18-99$ & $<.200$ & $<.370$ & -- & -- & $<5.00$ & $<.036$ & $<.170$ & $<.098$ & $<.570$ \\
\hline & & $05-06-99$ & -- & -- & -- & -- & -- & -- & -- & -- & -- \\
\hline & & $07-07-99$ & -- & -- & -- & -- & -- & -- & -- & -- & -- \\
\hline & & $08-31-99$ & -- & -- & -- & -- & -- & -- & -- & -- & -- \\
\hline \multirow[t]{7}{*}{ GWMW5 } & $(\mathrm{A}-03-06) 12 \mathrm{CDC}$ & $07-08-97$ & -- & -- & -- & $<.200$ & -- & $<.200$ & -- & -- & -- \\
\hline & & $01-28-98$ & -- & -- & -- & -- & -- & -- & -- & -- & -- \\
\hline & & $08-05-98$ & -- & -- & -- & -- & -- & -- & -- & -- & -- \\
\hline & & $03-19-99$ & $<.200$ & $<.370$ & -- & -- & $<5.00$ & $<.036$ & $<.170$ & $<.098$ & $<.570$ \\
\hline & & $05-04-99$ & -- & -- & -- & -- & -- & -- & -- & -- & -- \\
\hline & & $07-08-99$ & -- & -- & -- & -- & -- & -- & -- & -- & -- \\
\hline & & $09-02-99$ & -- & -- & -- & -- & -- & -- & -- & -- & -- \\
\hline \multirow[t]{8}{*}{ GWMW10 } & $(A-03-07) 07 C C D 2$ & $07-09-97$ & -- & -- & -- & $<.200$ & -- & $<.200$ & -- & -- & -- \\
\hline & & $07-09-97$ & -- & -- & -- & $<.200$ & -- & $<.200$ & -- & -- & -- \\
\hline & & $01-28-98$ & -- & -- & -- & -- & -- & -- & -- & -- & -- \\
\hline & & $08-03-98$ & -- & -- & -- & -- & -- & -- & -- & -- & -- \\
\hline & & $03-16-99$ & $<.200$ & $<.370$ & -- & -- & $<5.00$ & $<.036$ & $<.170$ & $<.098$ & $<.570$ \\
\hline & & $05-07-99$ & -- & -- & -- & -- & -- & -- & -- & -- & -- \\
\hline & & $07-09-99$ & -- & -- & -- & -- & -- & -- & -- & -- & -- \\
\hline & & $09-02-99$ & -- & -- & -- & -- & -- & -- & -- & -- & -- \\
\hline \multirow{6}{*}{\multicolumn{2}{|c|}{ SEDIMENT RETENTION BASIN F }} & $07-09-98$ & -- & -- & -- & -- & -- & -- & -- & -- & -- \\
\hline & & & METHYL- & - METHAC- & FURAN, & $\mathrm{H}-2 /$ & $0-18 /$ & DIBROMO & $1,2-\mathrm{DI}-$ & & \\
\hline & & & ETHYL- & RYLATE & TETRA- & $\mathrm{H}-1$ & $0-16$ & CHLORO- & PHENYL- & METRI- & \\
\hline & & & KETONE & METHYL & HYDRO- & STABLE & STABLE & PROPANE & HYDRA- & BUZIN & \\
\hline & & & WATER & WATER & WATER & ISOTOPE & E ISOTOPE & WATER & ZINE & SENCOR & \\
\hline & & & WHOLE & UNFLTRD & UNFLTRD & RATIO & RATIO & WHOLE & WATER & WATER & \\
\hline \multirow{2}{*}{\multicolumn{2}{|c|}{ LOCAL IDENTIFIER }} & DATE & TOTAL & RECOVER & RECOVER & PER & PER & TOT.REC & TOT.REC & DISSOLV & \\
\hline & & & (UG/L) & (UG/L) & (UG/L) & MIL & MIL & $(\mathrm{UG} / \mathrm{L})$ & (UG/L) & $(\mathrm{UG} / \mathrm{L})$ & \\
\hline \multirow[t]{4}{*}{ GRANDE } & WASH AT FOUNTAIN HILLS & $01-27-97$ & -- & -- & -- & -- & -- & $<4.00$ & $<5.00$ & -- & \\
\hline & & $08-26-97$ & -- & -- & -- & -- & -- & -- & $<5.00$ & -- & \\
\hline & & $02-04-98$ & $<3.30$ & $<.700$ & $<2.30$ & -- & -- & $<.428$ & -- & -- & \\
\hline & & $07-14-99$ & -- & -- & -- & -- & -- & -- & -- & $<.004$ & \\
\hline \multirow[t]{7}{*}{ GWMW4A } & $(\mathrm{A}-03-06) 12 \mathrm{CCA} 1$ & $07-08-97$ & -- & -- & -- & -- & -- & $<1.00$ & $<5.00$ & -- & \\
\hline & & $01-29-98$ & $<1.65$ & $<.350$ & $<1.15$ & -- & -- & $<.214$ & -- & -- & \\
\hline & & $08-05-98$ & $<1.65$ & $<.350$ & $<8.79$ & -62.3 & -8.83 & $<.214$ & -- & $<.004$ & \\
\hline & & $03-18-99$ & $<1.60$ & $<.350$ & $<9.00$ & -- & -- & $<.210$ & -- & $<.004$ & \\
\hline & & $05-06-99$ & -- & -- & -- & -- & -- & -- & -- & -- & \\
\hline & & $07-07-99$ & -- & -- & -- & -- & -- & -- & -- & -- & \\
\hline & & $08-31-99$ & -- & -- & -- & -- & -- & -- & -- & -- & \\
\hline \multirow[t]{7}{*}{ GWMW5 } & $(\mathrm{A}-03-06) 12 \mathrm{CDC}$ & $07-08-97$ & -- & -- & -- & -- & -- & $<1.00$ & $<5.00$ & -- & \\
\hline & & $01-28-98$ & -- & -- & -- & -- & -- & -- & -- & -- & \\
\hline & & $08-05-98$ & -- & -- & -- & -63.0 & -8.95 & -- & -- & -- & \\
\hline & & $03-19-99$ & $<1.60$ & $<.350$ & $<9.00$ & -- & -- & $<.210$ & -- & $<.004$ & \\
\hline & & $05-04-99$ & -- & -- & -- & -- & -- & -- & -- & -- & \\
\hline & & $07-08-99$ & -- & -- & -- & -- & -- & -- & -- & -- & \\
\hline & & $09-02-99$ & -- & -- & -- & -- & -- & -- & -- & -- & \\
\hline \multirow[t]{8}{*}{ GWMW10 } & $(A-03-07) 07 C C D 2$ & $07-09-97$ & -- & -- & -- & -- & -- & $<1.00$ & $<5.00$ & -- & \\
\hline & & $07-09-97$ & -- & -- & -- & -- & -- & $<1.00$ & -- & -- & \\
\hline & & $01-28-98$ & -- & -- & -- & -- & -- & -- & -- & -- & \\
\hline & & $08-03-98$ & -- & -- & -- & -67.0 & -8.89 & -- & -- & -- & \\
\hline & & $03-16-99$ & $<1.60$ & $<.350$ & $<9.00$ & -- & -- & $<.210$ & -- & $<.004$ & \\
\hline & & $05-07-99$ & -- & -- & -- & -- & -- & -- & -- & -- & \\
\hline & & $07-09-99$ & -- & -- & -- & -- & -- & -- & -- & -- & \\
\hline & & $09-02-99$ & -- & -- & -- & -- & -- & -- & -- & -- & \\
\hline \multicolumn{2}{|c|}{ SEDIMENT RETENTION BASIN F } & $07-09-98$ & -- & -- & -- & -- & -- & -- & -- & -- & \\
\hline
\end{tabular}


Table 7. Water-chemistry and stormwater-sediment chemistry data, Grande Wash, Fort McDowell Indian Reservation, ArizonaContinued

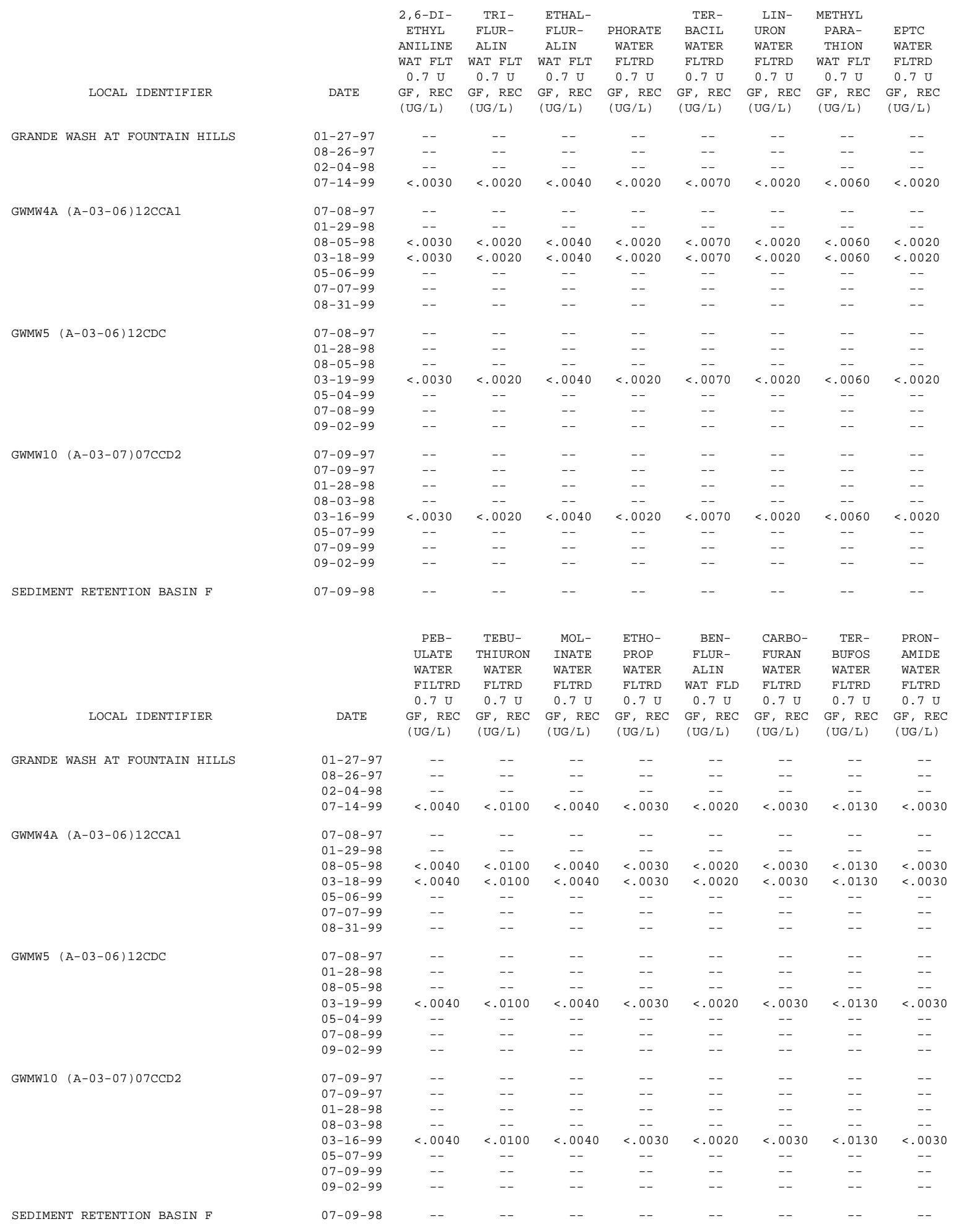


Table 7. Water-chemistry and stormwater-sediment chemistry data, Grande Wash, Fort McDowell Indian Reservation, ArizonaContinued

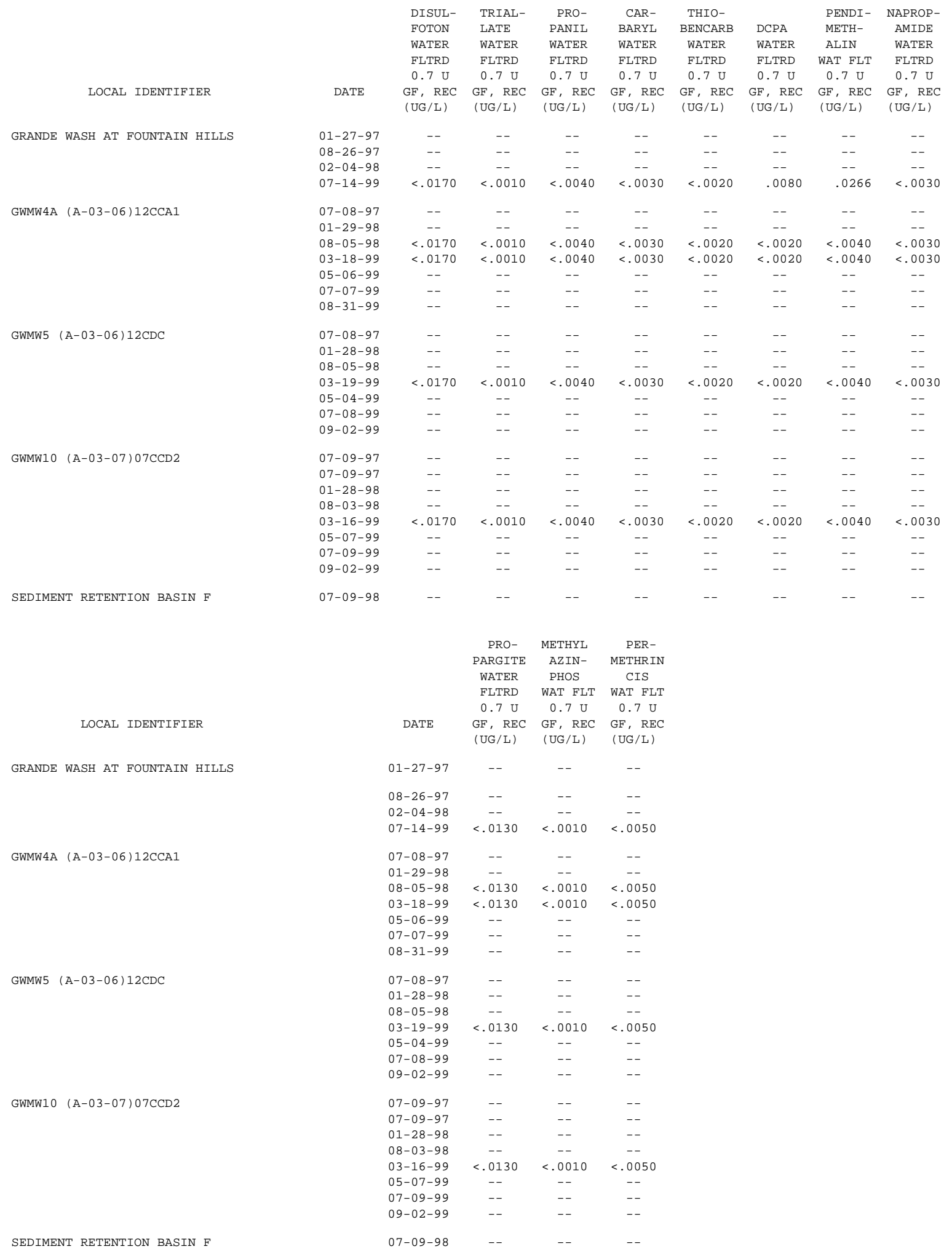

